\title{
BEYOND UNIVERSALISM AND RELATIVISM: THE EVOLVING DEBATES ABOUT "VALUES IN ASIA"
}

\section{Randall Peerenboom*}

From its humble and legally fragile beginnings, the international human rights movement has developed into a potent political force capable of influencing a nation's domestic politics. The growing power of the international human rights movement has led unsurprisingly to a backlash both in Asia and the West. ${ }^{1}$ Perhaps the most serious threat to the movement to date came when increasingly assertive Asian governments, buoyed by years of economic growth, issued the 1993 Bangkok Declaration challenging the universalism of human rights and criticizing the international human rights movement for being Western-biased.

This Article advances three main theses. First and foremost, it is time to move beyond universalism and relativism. The debate, often engaged in at an exceedingly abstract level, is no longer fruitful, in Asia or elsewhere. Most of the contested issues concerning human rights are too specific to be resolved by falling back on claims of "universalism" or "relativism."2

Second, the "Asian values" debate was not a single debate, not only about values in Asia, and not only about universalism versus relativism. Rather it was a series of debates about a range of issues. It is a mistake to reduce the many complex debates to the politically charged and easily resolved issue of whether authoritarian governments (sometimes) have invoked culture to deny citizens in their countries their rights. It does a disservice to the difficulty of the issues and the increasingly sophisticated and nuanced views of those who are trying to take diversity seriously to simply dismiss them as apologists for dictators. Put more bluntly, it is intellectually lazy and emblematic of the arrogant and narrow-minded ethnocentricism that has led

* Professor of Law, UCLA School of Law; J.D., Columbia Law School; Ph.D., Philosophy, University of Hawaii; M.A., Chinese Religions, University of Hawaii; B.A., Philosophy, University of Wisconsin-Madison; peerenbo@law.ucla.edu. This article grew out of an invitation to comment on recent discussions of Asian values in the Korea Journal, the results of which are published in volume $\mathbf{4 2}$ of that journal. I expand on my comments there and address several issues that I was unable to discuss due to space limitations. I would like to thank Roger Ames, Daniel Bell, Mike Dowdle, Tom Ginsburg, Kal Raustiala, and several anonymous reviewers for their helpful comments.

1. See, e.g., Laurence R. Helfer, Overlegalizing Human Rights: Intermational Relations Theory and the Commonwealth Caribbean Backlash Against Human Rights Regimes, 102 COLUM.L. REV. 1832 (2002). See also infra notes 136-137 and accompanying text (discussing concerns on the part of U.S. legal scholars that the human rights movement is encroaching on U.S. sovereignty).

2. As discussed infra, there are many different versions or understandings of "universalism" and "relativism." 
many in Asia, and elsewhere, to view the human rights movement as the latest neo-colonial attempt to impose with missionary zeal the values, institutions, and ways of life popular in the West on the Rest.

Third, the Asian values debates have evolved and will continue to evolve. We are now in the second round, with no indication that many of the issues will go away any time soon. In fact, just the opposite: although countless pundits have pronounced the debates about "Asian values" over, it now appears the battle is going to be a multi-round epic struggle along the lines of the fifteen-round "Thrilla in Manila" between Muhammed Ali and Joe Frazier. Of course, East-West comparisons have a long if often dubious history, ${ }^{3}$ and are likely to be with us as long as Americans waking up in Tokyo, Beijing, or Jakarta realize they are not in Kansas or Parisians in Paris, or Londoners in London, and vice versa. ${ }^{4}$ The current second round of debates on Asian values, or its more politically correct updated variant "values in Asia", 5 is one strand of this larger East meets West dialogue. It is now time to assess where we are and where we are going. While the Bangkok declaration led to a flurry of books and articles, there has been no systematic attempt to assess the second round of debates or where the debates are likely to head in the future. ${ }^{6}$

This article proceeds in three parts corresponding to the chronological evolution of the debate. The first round of the Asian-values debates began with the provocative remarks of Lee Kuan Yew and Mahathir Mohammed, gained geopolitical support from China's issuance of its White Paper on Human Rights in 1991, and reached its apogee with the issuance the 1993 Bangkok Declaration, the political manifesto for round one. While a wide range of issues was discussed, the first round had two main, related, but nonetheless distinct, focal points. ${ }^{7}$ The first area of contention was human rights,

3. For an engaging account of the use and abuse of the Chinese legal system as a foil for Western theorists over the centuries, see Teemu Ruskola, Legal Orientalism, 101 MICH. L. REV. 179 (2002).

4. To be sure, New Yorkers who wake up in Kansas, or L.A. for that matter, will realize they are not in New York. Of such differences, comparisons are made.

5. Both "Asian values" and "values in Asia" are misleading to the extent that the debate is not only about values. Nevertheless, values are central to many of the debates. Accordingly, I follow the accepted practice in referring to the debates in such terms.

6. One work, published after this article was first written, provides an excellent overview of the issues from a political, historical, and religious perspective. See MICHAEL D. BARR, CULTURAL POLITICS AND ASIAN V ALUES: THE TEPID WAR (2002) (arguing that the debates over Asian values are far from over as Asian countries attempt to negotiate their own form of modernity).

7. See, e.g., Yash Ghai, Human Rights and Governance: The Asia Debate, Asia Foundation Center for Asian Pacific Affairs, Occasional Paper No. 4, Nov. 1994; HUMAN RIGHTS AND INTERNATIONAL RELATIONS IN THE ASIA-PACIFIC REGION (James T.H. Tang ed., 1995); HUMAN RIGHTS AND CHINESE VALUES: LegAL, PHILOSOPHICAL, AND POLITICAL PERSPECTIVES (Michael Davis ed., 1995); WM. THEODORE DE BARY, ASIAN V ALUES AND HUMAN RIGHTS: A CONFUCIAN COMMUNITARIAN PERSPECTIVE (1998); AMARTYA SEN, HuMAN RIGHTS AND ASIAN VALUES (1997); Bilahari Kim Hee P.S. Kausikan, An East Asian Approach to Human Rights, 2 BUFF. J. INT'LL. 263 (1995-96); Bilahari. Kausikan, Governance that Works, J. DEMOCRACY 24, Apr. 
especially the issue of universalism versus relativism, but also including other issues such as the priority of rights and the compatibility of Confucianism, Buddhism, and Islam with democracy and human rights. The other main area of contention was economics: in particular whether authoritarian or democratic regimes are better able to achieve sustained economic growth and whether Asian versions of capitalism are superior to the varieties of capitalism found in Western liberal democracies. Despite the attempts of some scholars to discuss the issues in an even-handed and nuanced fashion, the first round of debates was heavily politicized and suffered from excessive abstraction and the lack of a solid empirical foundation for many of the sweeping claims made by both sides.

The second round of debates arose in response to the Asian financial crisis. ${ }^{8}$ The financial crisis struck a body blow to advocates of Asian values, sending them reeling into the ropes (most notably with respect to economic issues, less so on rights issues, with the issue of democracy somewhere in between). As the scope of the financial crisis became apparent, many opponents of Asian values rushed to their corners claiming victory for universalism and blaming the crisis on Asian values. However, as Asian economies struggled to their feet and fought their way back to prosperity, advocates of Asian values raised themselves off the mat and mounted a counterattack. Some questioned to what extent Asian values were a cause of the crisis. ${ }^{9}$ On the contrary, Asian values were said to have played an important role in the

1997, at 24; HUMANRIGHTS: CHINESE AND DUTCH PERSPECTIVEs (Peter Baehr et al. eds., 1996); Roger T. Ames, Continuing the Conversation on Chinese Human Rights, 11 ETHICS \& INT'L AFF. 177 (1997); DEALING WITH HUMAN RIGHTS: ASIAN AND WESTERN VIEWS ON THE VALUE OF HUMAN RIGHTS (Martha Meijer ed., 2001) (containing essays from the mid-1990s, despite the recent publication date). For a collection of excellent essays addressing many of the key issues in the first round of the debate, see THE EAST ASIAN CHALLENGE FOR HUMAN RIGHTS (Joanne R. Bauer \& Daniel A. Bell eds., 1999). For a review of this work and an analysis of first round issues, see Randall P. Peerenboom, Human Rights and Asian Values: The Limits of Universalism, 7 CHINA REV. INT'L 295 (2000). Asian values is one of the main themes in NeGotiating CUlTURE AND HUMAN RighTS (Lynda S. Bell et al. eds., 2001), a work that came out after the Asian financial crisis but mainly addressed issues raised in the first round.

8. DEMOCRACY, MARKET ECONOMICS \& DEVELOPMENT: AN ASIAN PERSPECTIVE (Farrukh Iqbal \& Jong-Il You eds., 2001) [hereinafter DEMOCRACY, MARKET ECONOMICS \& DEvelopmENT]. For other second round works, see Kenneth Christie \& Denny Roy, The Politics of Human Rights in East Asia (Peter Van Ness ed., 2001); Karen Engle, Culture and Human Rights: The Asian Values Debate in Context, 32 N.Y.U. J. INT'L L. \& PoL. 291, 323 (2000); BARR, supra note 6; MARINA SVENSSON, DEBATING HUMAN RIGHTS IN CHINA, 18991999: A CONCEPTUAL AND POLITICAL HISTORY (2002); STEPHEN ANGLE, HUMAN RIGHTS AND CHINESE THOUGHT: A CROSS-CULTURAL INQUIRY (2002) (taking as his point of departure two claims made by Liu Huaqiu, head of the Chinese delegation to the 1993 U.N. World Conference on Human Rights in Vienna). See also 41-42 KOREA J., 2001-02 (containing essays on Asian values). The journal has decided to pursue the theme of Asian values over a two to three year period. See Editor's Note, Asian Values and the New World Order, 41 Korea J., 2001, at 264.

9. Even opponents of Asian values question this. See, e.g., Francis Fukuyama, Asian Values in the Wake of the Asian Crisis, in DEMOCRACY, MARKETECONOMICS \& DEVELOPMENT, supra note 8, at 149-68. 
recovery. The high incidence of family businesses and the relational nature of much business in Asian countries helped cushion the shock of the Asian financial crisis by providing a social welfare network in countries where the social security system is typically weak and by making it possible to raise capital to start over, thus contributing to a speedy economic recovery. Others have argued that there are still many aspects of (East) Asian capitalism worth maintaining. ${ }^{10}$

The fall of Suharto and subsequent democratization in Indonesia, the strengthening of democracy in Thailand, and the higher pre-crisis growth rates in the Philippines put advocates of the view that a strong (soft-authoritarian) ruling regime was necessary to ensure economic growth and stability on the defensive. On the other hand, many Asian countries that have democratized continue to suffer major socioeconomic problems and struggle to maintain social order and stability." Meanwhile, China continues to prosper, and Singapore and Hong Kong did not suffer from the crisis as much as other economies in Asia. ${ }^{12}$ Furthermore, Asian values continue to be invoked on human rights issues even in democratic Asian states in support of a different balance between the interests of the individuals and group and to oppose what some considered to be the hegemony of liberalism. ${ }^{13}$

In contrast to the first round, the second round of debates has been much less politicized. It has been dominated by academics rather than politicians, and the academics have been able to draw on several insightful discussions of

10. Daniel A. Bell, East Asian Capitalism: Towards a Normative Framework, GLOBAL ECON. REV., Fall 2001, at 73. See also K.S. Jomo, Rethinking the Role of Government Policy in Southeast Asia, in RETHINKING THE EAST ASIA MIRACLE 461-508 (Joseph Stiglitz \& Shahid Yusuf eds., 2001).

11. See infra notes 78-80 and accompanying text.

12. China has reported growth rates over $7 \%$ for the last several years with predictions for future growth in the near term in the same range. See People's Daily, IMF: China's Growth Rate to Reach 7 Percent in 2002, available at http://fpeng.peopledaily.com.cn/200204/19/eng 20020419_94353.shtml (last visited Nov. 3, 2003). See also G. Pascal Zachary, From Iceland to Botswana, Small Nations Prosper, WALST. J., Feb. 25, 1999, at B1 ("Singapore, the smallest country in Southeast Asia, has been the least hurt by the region's economic crisis."). Hong Kong's growth rate of GDP fell in 1998, but rebounded to $3.1 \%$ in 1999 and $10 \%$ in 2000 and then fell sharply in 2001 to $0.1 \%$ due to the general economic slowdown in industrial countries. Growth picked up in 2002 and increased again in 2003 despite the negative impact of SARS. See Asia Development Bank's Outlook for Hong Kong, at http://www.adb.org/ documents/ books/ado/2002/hkg.asp (last visited Nov. 3, 2003).

13. See Nikhil Aziz, The Human Rights Debate in an Era of Globalization: Hegemony of Discourse, in DEBATING HUMAN RIGHTS, supra note 8, at 32; Takashi Oshimura, In Defense of Asian Colors, in THE RULE OF LAW: PERSPECTIVES FROM THE PACIFIC RIM 141 (2000), available at http://www.mcpa.org/rol/perspectives.htm (last visited Nov. 3, 2003) (claiming that the individualist orientation of [liberal democratic] rule of law is at odds with Confucianism and the "communitarian philosophy in Asia"); Joon-Hyung Hong, The Rule of Law and Its Acceptance in Asia, in THE RULE OF LAW: PERSPECTIVES FROM THE PACIFIC RIM 145 (2000) (noting the need to define rights and rule of law in a way that is acceptable to those who believe in "Asian Values"). 
the main issues in the first debate. ${ }^{14}$ In addition to the role of Asian values in the financial crisis and subsequent recovery, one of the main issues in the second round has been whether there is sufficient common ground within Asia with respect to values, human rights, and economic issues for the term "Asian values" to be useful or whether we should move beyond Asian values. This issue was raised by opponents of Asian values in the first round, but it has now become more central, with the discussion more focused and mutually engaged; rather than talking past each other, both sides are critically examining the arguments for and against invoking Asian values. In addition, there has been a transition in the second round from the concern about whether indigenous traditions, particularly Confucianism, are compatible with the hallmarks of modernity - capitalism, democracy, rule of law, and human rightsto the acknowledgement or stipulation that they simply must be if they are to be relevant, and thus they must adapt or be adapted accordingly. ${ }^{15}$ Therefore, the focus has shifted to articulating Confucian or other Asian variants of capitalism, democracy, rule of law, and human rights, rather than radical alternatives to them. In the process, scholars have begun to pay greater attention to economic, political, and legal institutions and practices. With this shift toward more concrete situations, the futility of abstract discussions of universalism versus relativism has become even more apparent.

In the third and concluding section, I consider where the debates are likely to head next and offer some thoughts on what is needed to advance the discussion and help resolve some of the persisting impasses. In my view, there is a need for both theoretical and empirical work. To date, the efforts to develop Confucian or other Asian alternatives to liberal democracy (broadly understood to include libertarians, classical liberals, and welfare liberals) have suffered from a certain ad hoc nature, resulting in piecemeal tweakings of liberalism that do not add up to a coherent alternative political theory. To build a more coherent theory, we first need to complement the broad quantitative studies that have found regional differences in rights performance with more detailed empirical work that clarifies the differences in institutions and

14. See, e.g., THE EAST ASIAN CHALleNGE FOR HuMAN RIGHTS, supra note 7. See also Joseph Chan, The Asian Challenge to Universal Human Rights: A Philosophical Appraisal, in HUMAN RIGHTS AND INTERNATIONAL RELATIONS IN THE ASIA-PACIFIC REGION, supra note 7, at 25-38; Ghai, supra note 7; Michael C. Davis, Constitutionalism and Political Culture: The Debate over Human Rights and Asian Values, 11 HARV. HUM. RTS. J. 109 (1998).

15. As discussed infra, fundamental Islam is a notable exception to this trend to seek accommodation with modernity. Despite the presence of Muslim majorities in Indonesia and Malaysia, Islam has not been central to debates over Asian values. This may be explained in part by Lee Kuan Yew's preference for Confucianism and Mahathir's emphasis on the values of hard work of Chinese communities throughout Asia, which have fuelled prosperity among Chinese in Malaysia and elsewhere. It may also have been due to a reluctance to fan the flames of Islamic fundamentalism. While critical of aspects of liberal modernity, particularly with respect to social values, Lee, Mahathir and the leaders of other Asian states have endorsed capital markets and the economic base of modernity. 
practices within Asia, differences in outcomes on specific issues, and the reasons for such differences. ${ }^{16}$ The insights gained from these more finely honed empirical studies may then be synthesized and systematized to develop a comprehensive, coherent alternative theory to liberalism that is consistent with modernity.

While it is not possible to sum up in a tidy fashion all of the many issues discussed in the various rounds of the debates, and while in some cases hard and fast conclusions must await further empirical work, certain points stand out. Clearly, the debates about Asian values are not over, though the debates have moved beyond broad and unhelpful claims about universalism versus relativism. Although the range of diversity needs empirical verification, there is considerable diversity within Asia and between Asian and Western countries with respect to values, levels of economic development, institutions, laws, and outcomes in particular cases. Furthermore, while empirical studies show no clear winner with respect to the general issue of whether democratic or authoritarian regimes are more likely to lead to economic growth, several more specific conclusions may be drawn that lend some support to a "growthfirst" approach. What is clear is that democracy is no panacea. It will not necessarily lead to economic growth or even to a significant improvement in the protection of human rights in many cases. ${ }^{17}$

It also bears highlighting that advocates of allegedly universal human rights often criticize Asian countries for practices that are common in Western countries and indeed are an inevitable part of any legal system. All legal systems localize international human rights in a variety of ways. All must deal with tradeoffs between first generation civil and political rights and second generation social, economic, and cultural rights, and between individual freedom and group rights or social stability. ${ }^{18}$ In general, the forms and legal techniques of reconciliation are the same or similar in Asian and in Western countries, though the substantive outcomes of how each country reconciles such conflicts differ for many reasons. Despite the likelihood of greater convergence as a result of pressures from the international human rights movement and the forces of globalization more generally, there will be areas of divergence between countries in Asia and elsewhere in the world, and within Asia, in part because of differences in values and in part because of the path-dependency of institutions, customs, and lifeforms. Thus, "Asian values"

16. See infra notes $24-26$ for several multiple-country studies that have found significant differences by region across a range of rights.

17. Democracy appears to be related to both economic growth and human rights in a nonlinear way, with the human rights benefits of democracy occurring only once democracy is consolidated. See infra notes 111-113,161.

18. As discussed infra, many democratic countries, including several in Asia, no longer confront the broad issue of whether economic growth requires the postponement of democracy. Nevertheless, they regularly deal with a range of more specific issues that involve the conflict between first and second or third generation rights. 
or "values in Asia" will remain an issue. Replacing references to "Asian values" with "values in Asia," while more politically correct, will not alter the fundamental reality that differences in values (whether in Asia or Western countries) undermine to some degree the universality of the human rights regime as an empirical matter and present a challenge to the normative claim that human rights should be interpreted and implemented in a similar manner everywhere. In many cases, differences in values and other contingent circumstances will and should lead to differences in the ways human rights are interpreted and implemented. The overly politicized arguments of some Asian governments in the first round should not lead to the premature and false conclusions that differences in values either do not exist or do not matter.

\section{THE FIRST ROUND}

\section{Rights Issues}

\section{Universalism versus relativism}

\section{Clarifying Terminology: A Brief Introduction to the Philosophical Literature}

The first round of the Asian values debates proceeded, for the most part, without drawing on the rich, if sometimes confusing and ultimately inconclusive, philosophical literature on universalism and relativism. ${ }^{19}$ I discuss some explanations for why this is so when I consider the attempt to move the debate away from universalism and relativism in the second round. Nevertheless, it may be helpful to set out some of the more common definitions and positions in the philosophical literature in order to provide a context for the discussion of universalism and relativism in the various rounds of the debates. Doing so will also bring out more clearly both points of agreement and contention among the various disputants. ${ }^{20}$

Descriptive relativism holds that the moral beliefs, standards, values, or principles of individuals, groups or societies conflict in fundamental ways, and thus disagreements will remain in some cases even after all factual and

19. Some commentators took a philosophical approach though they do not necessarily delve at all or very deeply into the debates about moral realism or the various forms of normative or metaethical relativism. See, e.g., Michael Barnhart, Getting Beyond Cross-Talk: Why Persisting Disagreements Are Philosophically Nonfatal, in NEGOTIATING CULTURE AND HUMAN RIGHTS, supra note 7, at 45-67.

20. A good place to start for a general overview of the philosophical literature is MORAL RELATIVISM: A READER (Paul K. Moser \& Thomas L. Carson eds., 2001). For a discussion of universalism and relativism as applied specifically to human rights, see JACK DONNELLY, UNIVERSAL HUMAN RIGHTS IN THEORY AND PRACTICE 109-42 (1989); Alison Dundes Renteln, The Unanswered Challenge of Relativism and the Consequences of Human Rights, 7 HUM. RTS. Q. 514 (1985). 
logical disputes are resolved. ${ }^{21}$ These fundamental differences may be due to culture; variation in the personality, psychology, or experiences of individuals; or to other factors such as levels of economic development, the relative stability or instability of the state, and the likelihood of civil war or terrorism. Virtually no one denies the truth of descriptive relativism. ${ }^{22}$ Broad multicountry studies have found significant regional differences with respect to democratization, ${ }^{23}$ labor rights, ${ }^{24}$ women's rights ${ }^{25}$ and personal integrity rights. ${ }^{26}$ Most of the debate therefore is over two other forms of relativism, normative and metaethical relativism, or other related issues.

Normative relativism is the view that something is wrong or blameworthy if some person or group holds them to be wrong or blameworthy. One common objection to individual normative relativism (or moral subjectivism) is that if it were true, there would be little point in arguing over moral issues, though we obviously do, assuming there were no factual or logical issues in dispute. Of course, those sympathetic to individual moral relativism would generally agree with this observation, but not see it as a problem for their position. Clearly there are pragmatic reasons for trying to persuade others of

21. See Richard Brandt, Ethical Relativism, in THE ENCYCLOPEDIA OFPHILOSOPHY, Paul Edwards, ed., Vol. 3, 75 (1967).

22. But see Karl Duncker, Ethical Relativity? (An Inquiry into the Psychology of Ethics), 48 MiND 39 (1939) (arguing that the "inner laws" of ethical valuation preclude different ethical valuations of the same act). Based on the then popular Gestalt theory, this kind of radical challenge to descriptive relativism challenges whether seemingly similar acts are really similar by specifying the "situational meaning" of the act and the different non-moral beliefs that affect how the act is interpreted in a particular context. Even if successful at undermining the relativist position that there are moral disagreements about the same thing, this approach is too successful in that it would undermine the universalist position which requires common moral valuations of the same thing, not situational-specific and thus different things. See MICHELEE MOODY-ADAMS, The Empirical Underdetermination of Descriptive Cultural Relativism, in FIELDWORK IN FAMILIAR PLACES 29-43 (1997).

23. Steven Levitsky \& Lucan Way, Autocracy by Democratic Rules: The Dynamics of Competitive Authoritarianism in the Post-Cold War Era (2002), available at http://apsa proceedings.cup.org/index.htm.

24. Layna Mosley \& S. Uno, Racing to the Bottom or Climbing to the Top? Foreign Direct Investment and Human Rights (2002), available at http://apsaproceedings.cup.org/ index.htm. (finding strong regional relationship between regions and labor rights, and that the Asian and Pacific regions were not as protective of labor rights as Western Europe, Central and Eastern Europe, although they were more protective than the Middle East, North Africa and Latin America and on par with Sub-Saharan Africa).

25. Clara Apodaca, Measuring Women's Economic and Social Rights Achievement, 20 HUM. RTS. Q. 139 (1998) (finding that regional coefficients play a larger role than GNP in the achievement of women's economic and social rights, although the regional identification of Asian and African explains less variation than the Middle East regional designation).

26. David Reilly,Diffusing Human Rights (2003), available at proceedings@ apsanet.org (finding that regional variations were important with respect to factors relating to personal integrity); Frank B. Cross, International Determinants of Human Rights and Welfare: Law, Wealth or Culture, 7 IND. INT'L \& COMP. L. REV. 265 (1997) (finding that cultural values are important and that Western nations have a higher level of freedom from government intrusion even after controlling for GDP and other factors). 
one's views. However, once all the factual and logical issues have been cleared up and each side has set out its reasons, and yet the parties continue to disagree, there is little to be gained from further argumentation about who is right or whose view is better. Stamping one's foot and insisting that one is "really" right or calling the other person irrational will not advance matters. At that point, one must either choose to impose one's views on the other through various forms of coercion or just walk away, perhaps agreeing to disagree. A second objection to individual normative relativism is that many people find it odd to think that if someone sincerely believed after careful thought and discussion that rape was morally acceptable, it would be so, at least for that person. ${ }^{27}$ If individual normative relativism fails, then it may seem that group or social normative relativism should also fail, as the latter simply aggregates many individual views. Even if a particular group believes that rape is morally acceptable, why should greater numbers matter to whether something is morally right or wrong $?^{28}$ Extreme normative relativism would hold that all issues depend on the views of the group or individual. Moderate normative relativism would hold that some normative issues depend on the views of the group or the individual.

Metaethical relativism includes a variety of different positions that share common ground in rejecting the idea that there is one correct answer to moral issues. ${ }^{29}$ Extreme metaethical relativists assert that there is never a correct (or objectively true) answer to any moral issue. Moderate metaethical relativists hold the view that there may be a correct (or objectively true) answer to some moral issues and not others. In rejecting a single correct answer, metaethical

27. On the other hand, the views of great religious leaders are often at odds with the established norms of the time. As noted infra, if numbers are irrelevant with respect to the correctness of moral issues, then they are irrelevant whether one is a rapist or a saint. That everyone condemns a rapist, or groups that endorse rape as wrong, can no more prove rape is wrong than the fact that many people at one time believed slavery was morally acceptable can prove slavery was acceptable.

28. An anti-foundational pragmatic or conventionalist response would be that right or wrong means relative to the justification practices of some individual or group of people. Socalled "moral facts" are just those beliefs that are particularly hard to dislodge. Moral objectivity in this view means the moral judgment in question commands near universal acceptance within the relevant group. See generally RICHARD RORTY, PHILOSOPHY AND THE MIRROR OF NATURE (1979). As a descriptive matter, different groups and individuals will have different justificatory practices. In some cases, reasonable people will continue to disagree even after all the points of contention have been fully discussed. Again, the issue then becomes what one is willing to do beyond non-coercive persuasion to change the other's views and ensure compliance.

29. Metaethical relativists may be noncognitivists (including emotivists) who view ethical statements as expressing the attitudes of the speaker but not something that is or can be true or false. It should be noted that noncognitivists need not deny that people may seek to persuade others as to their views or are capable of giving reasons for their moral beliefs or even of using coercion to force others to accept their beliefs. 
relativists are antirealists. ${ }^{30}$ Some antirealists are naturalists who believe that talking about objective truth and falsity in morals assumes a correspondence theory of truth that is inappropriate or otherwise analogizes moral statements to statements of facts that are amenable to scientific testing and verification. The problem is that moral problems do not seem much like scientific problems. Reasonable people will give up their belief that the earth is flat if you show them a picture of the earth from the moon. However, moral problems do not lend themselves to the same kind of testing. As we all know, moral debates often continue endlessly without any irrefutable or compelling proof or argument for either side. ${ }^{31}$

In contrast to antirealists who argue that there is no single correct answer (or objective truth) to (some) moral issues, arealists are agnostic on the issue of moral realism and objectively true answers to some, or all, moral issues. For some arealists, the issue is an epistemological issue: even if there is a single correct answer, we cannot know it or be (reasonably) sure we know it. For others, the issue is more a justificatory (or pragmatic) one; even if we think we know the single correct answer, we cannot persuade others that we know it. Given that reasonable people can, and often do, disagree about the morality of certain acts, moral realism is irrelevant in practice; it provides no help when we need it the most - when we are dealing with controversial moral issues where reasonable people continue to disagree after both sides have fully aired their views. ${ }^{32}$ To a considerable extent, Rawls' recognition of the fact of pluralism has shifted the philosophical focus away from the endless debates over moral realism toward the possibility of achieving an overlapping consensus on controversial normative issues. ${ }^{33}$ Although his arguments were originally designed for the domestic American political context, both he and others have applied the fact of pluralism and the idea of an overlapping con-

30. Whether antirealism commits one to metaethical relativism is much debated. For the argument that antirealists have difficulty avoiding metaethical relativism, see Moser \& Carson, supra note 20 , at $287-88$.

31. In analogizing to science, naturalism also shifts the emphasis away from philosophical theorizing and a priori or abstract analysis to empirical studies of the consequences of specific moral beliefs or claims in particular contexts. After all, the scientific method is valued precisely because it works-because it "delivers the goods," as it were by aiding in predicting and controlling events in daily life. This shift toward a more empirical-based, consequentialist approach is consistent with the type of pragmatism argued for in this Article.

32. See infra note 210 and accompanying text.

33. See John RaWLS, Political Liberalism (1993). Pluralism is also sometimes used to refer to the view that there are multiple, irreducible fundamental values that may conflict in particular circumstances. See George Crowder, Pluralism and Liberalism, 42 POL. STUD. 293 (1994). See also Isaiah Berlin and Bernard Williams, Pluralism and Liberalism: A Reply, 42 POL. STUD. 306 (1994). For the challenges to universalism rising from pluralism of values in this sense, see infra discussing conflicts among rights and the difficulty establishing and justifying hierarchies of rights and rules to govern when certain rights may be traded off to ensure other rights. 
sensus to the international political order and human rights. ${ }^{34}$ While descriptive relativism does not entail normative or metaethical relativism or arealism, it does lend support to the arealist position in that the existence of widespread disagreement suggests that there is reasonable disagreement over many human rights issues in Asia and elsewhere and that, as a practical matter, appeals to moral realism will not help settle the debates.

That said, what follows from the existence of reasonable disagreement is much debated. ${ }^{35}$ For some, as discussed shortly, it suggests that states, groups within states, or individuals should be given a wider margin of appreciation to set their own policies and adopt ways of life based on their preferred moral principles. Yet there remains much disagreement about what the reasonable limits of the margin of appreciation should be and what should be done when the reasonable limits are exceeded. For instance, few would object to non-coercive attempts to persuade others to change their views, but there may be disagreement about whether one may criticize others based on standards they do not hold (an external standard) or whether one should appeal only to standards shared by the individual or group (an internal standard). ${ }^{36}$ Liberals, in particular, have problems determining what the limits of tolerance should be and explaining why it is justifiable in some circumstances to force others to accept their beliefs. The liberal principle of tolerance also sits uneasily with the view of many liberals, a view shared by many non-liberals, that to hold an ethical position requires that one be willing to universalize it and act in accordance with the rule.$^{37}$ If abortion is wrong, then it is wrong for others in other societies as well, at least if they are similarly situated. One should be willing to tell others in a similar situation that their actions must also accord with the moral principles one holds. If one is a vegetarian who believes eating meat is wrong, then one should believe that all similarly

34. See John RaWls, The LAW OF PEOPLES (1999).

35. I set aside the debate about whether in a pluralistic political context parties should bracket deeply felt but contentious beliefs that are not accessible to others. See RAWLS, POLITICAL LIBERALISM, supra note 33. For a nuanced critique, see KENT GREENAWALT, PRIVATE CONSCIENCES AND PUBLIC REASONS (1997). See also Carol Gluck, The Call for a New Asian Identity: An Examination of the Cultural Arguments and Their Implications, Japan Programs Occasional Papers, no. 5 [Carnegie Council on Ethics and International Affairs], p. 6) (arguing that people ought to contain culture in international relations to the greatest possible extent). Roger Ames has challenged this view as naive arguing that Gluck's suggestion assumes that the existing international discourse is innocent-that it is not already burdened with ethnocentric assumptions. But "[c]ulture is pervasive and inescapable. And perhaps the only position that is fraught with more difficulty and danger than struggling to make generalizations about other cultures and attempting to deal with differences head-on, is failing to do so." Ames, supra note 7, at 188-190. There is also disagreement about the role and utility of philosophical discussion.

36. Richard A. POSNER, THE PRoblematics OF MORAL ANd Legal. TheORY 8 (1999) (arguing that we cannot, except for polemical effect, call another culture immoral unless we add "by our lights," but also rejecting "vulgar relativism that teaches that we have a duty to tolerate cultures that have moral views different from [our own]").

37. See Betsy POSTOW, Dishonest RELATIVISM 45 (1979). 
situated persons should be vegetarians, and one is required to show some practical commitment to acting accordingly, presumably by, at minimum, trying to persuade others to become vegetarians. ${ }^{38}$ However, this response is problematic. First, the proviso that others must be similarly situated opens the door to considerable variation in practice. It is often difficult to state which differences are relevant and which are not. Does it matter, for instance, if one lives in Tibet where vegetables are scarce, and the main source of food is yak? Second, there is likely to be considerable disagreement about what satisfies the requirement of a practical commitment for different acts in various contexts. Presumably, attempts at non-coercive persuasion would fall toward the minimal end of the practical-commitment scale. But must one always try to persuade others to become a vegetarian, every chance one gets, or only when it is convenient or the subject happens to arise? If others refuse to become vegetarians, should one refuse to eat with them or castigate them every time one shares a meal? Would it matter if the parties had discussed the issue at length in the past without any resolution-indeed, with each side having become more convinced that he or she was right and the other wrong? Perhaps it is enough for each to act in accordance with his or her beliefs and lets others follow their own beliefs. On the other hand, some issues will seem so important and clear that one may be willing to fight for them using coercive force, if necessary, to compel others to comply.

In contrast to the various forms of relativism, surprisingly little attention has been given to stating with any clarity what the universalist position is. Yet stating precisely what the universalist position is and what the differences between universalists and relativists of various stripes are with respect to particular issues is more difficult than often assumed, particularly when both sides hold moderate, as opposed to extreme, forms of universalism or relativism. Extreme moral universalism holds that the correctness (or objective truth) of moral issues does not depend on culture or the views of any group or individual. $^{39}$ Although other circumstances, such as level of economic development, may be relevant to moral issues, there is still a single, universally correct answer that applies to all those similarly situated. As with normative and metaethical relativism, there is a moderate version of moral universalism that holds that culture is irrelevant to the correctness of some, but not necessarily all, issues. The human rights variant of extreme moral universalism is that human rights apply everywhere regardless of culture and in some cases, regardless of other contingent factors such as varying degrees of economic, political or legal development. ${ }^{40}$ Further variants are possible

38. See id.

39. See DONNELLY, supra note 20, at 109.

40. The inside cover to THE EAST ASIAN CHALLENGE FOR HUMAN RIGHTS, supra note 7, states that "The 'Asian values' argument within the international human rights debate holds that not all Asian states can be or should be expected to protect human rights to the same degree due 
by distinguishing between the content, justification, interpretation, and implementation of rights. ${ }^{41}$ When stated as they usually are, at a high level of abstraction and generality, many human rights appear uncontroversial. However, controversy arises when these general principles must be applied in particular circumstances. In this sense, universalism is opposed to particularism, the view that generalizations are less accurate and helpful than specific judgments about particular cases.

To sum up this quick overview, as is true in the case of most longdebated philosophical issues, there is something to be said for and against both universalism and relativism. Simply put, few dispute the key claim of descriptive relativism that different individuals, groups, and societies disagree over particular normative and human rights issues. Nevertheless, there is considerable dispute about the range of fundamental disagreement and the reasons for it. $^{42}$ As for normative relativism, the main criticisms are that it is self-refuting, inconsistent, and has problems justifying why the fact of differences (the descriptive level/"is") is normatively significant (the prescriptive level/ "ought"). Conversely, universalism and moral realism have epistemological problems in moving from the possibility of there being right answers to how we know them, and justification problems in showing that such answers are indeed the right answers. Unlike scientific disputes where there is a fallible, but nonetheless generally accepted and proven, method for testing the veracity of claims, there is no such method available for resolving moral disputes. While the lack of a criterion or method for resolving disputes as to what is morally right does not prove there is no right answer to moral questions, it renders the single answer debate moot, turning it into an academic debate without any practical consequences.

Of course, there have been a variety of responses to such worries. For instance, relativists try to overcome the self-refuting, inconsistency criticism by distinguishing between first order claims (moral judgments such as the belief that it is wrong to kill innocent babies) and second order claims or metaclaims about first order claims (such as the claim that moral judgments are relative). Conversely, universalists and realists deny that natural science provides the proper standard for knowing moral truths. Rather, we may appeal to a more limited practical reasoning. Relativists counter that even when both sides have aired their views completely and all factual matters are cleared up, reasonable people will still often disagree. Moreover, turning the tables on realists, they note that even if most people (all but one?) agree that an act or

to varying levels of economic, political, and legal development and to differing cultural views on the virtues and necessity of freedom."

41. See DONNELLY, supra note 20 , at 110 (defending a weak cultural relativism that holds that culture may be an important source of the validity of a moral rule or right and that permits deviations from universal human rights standards primarily with respect to the form in which they are implemented).

42. See MOODY-ADAMS, supra note 22. 
principle is morally correct or right, that they agree cannot provide the kind of proof that realists require. Universalists counter that it would be good evidence, if not conclusive, with some reiterating that the standard is not an apodictic certainty but a more fallible probabilistic one. At this point, the views of the two sides tend to merge around some form of moderate universalism or relativism. Although the moderate forms may differ in their orientations, rhetoric, and deep philosophical commitments, they tend to produce similar results in practice.

In what follows, I rely on a variety of different arguments and strategies to counter extreme forms of universalism. I first challenge the universalists' assertion that there is a broad, pragmatic consensus regarding human rights. ${ }^{43}$ In support of particularism, I show that the broad consensus that seems to exist when rights are stated in a general, abstract form gives way to disagreement when the rights need to be specified in more particular contexts. I also argue that pluralism (the existence of multiple, irreducible fundamental values) undermines universalism in practice as countries prioritize rights differently. ${ }^{44}$ In addition, I side with those who maintain that epistemological and justificatory problems render moral realism irrelevant. As a result, I support a pragmatic form of metaethical relativism that shifts the focus from philosophical discussions of moral objectivity, moral realism, and the logical weaknesses of normative relativism to pragmatic considerations of how best to ensure compliance with rights in specific contexts and, in particular, to considerations of how far one is willing to go to ensure compliance once persuasion fails. Most fundamentally, however, I argue that technical philosophical discussions cannot help us solve the most pressing issues in the debates over Asian values. Accordingly, I join the rising chorus of those who claim that it is time to move beyond the strident debates over extreme forms of universalism and relativism and to focus our energies instead on specific issues that arise in promoting human rights with the ultimate aim being to improve people's lives.

Descriptive Relativism, Overlapping Consensus, and the Margin of Appreciation: The Need for More Detailed Empirical Studies to Gauge the Breadth and Depth of Agreement and Disagreement

Some scholars have tried to sidestep the universalism-versus-relativism issue by claiming that the Asian-values debates are not a threat to universal human rights in that Asian governments are not out to deny human rights across the board. Thus Bauer and Bell portray the debates as an opportunity for the current human rights regime: "The challenge is about seeing how inclusive the rights regime can become while still realizing its essential 
purpose: to promote and protect vital human interests." ${ }^{45}$ While they see the Asian-values debates as putting pressure on the human rights regime to broaden its horizons to accommodate Asian voices, they also claim that Asians must rise to the challenge and "locate themselves in the discourse of universality ...."46

Despite the wisdom in calling on both (or rather all) sides to seek out areas of consensus and to try to overcome divisions, it is a mistake to pretend that the Bangkok Declaration and the views of many advocates of Asian values are not a threat to universalism. The Bangkok Declaration's assertion that human rights must reflect the particular circumstances of particular countries at a particular time indicates that it is precisely the universality of human rights that is at stake, though not at the level of whether rights are good or bad in total. ${ }^{47}$ It is true that Asian leaders stopped short of denying outright the universality of all human rights. As Singapore's former Minister of Foreign Affairs, Wong Kan Seng observed, "Diversity cannot justify gross violations of human rights. Murder is murder whether perpetrated in America,

45. THE EAST ASIAN CHALLENGE FOR HUMAN RIGHTS, supra note 7, at 3.

46. Id.

47. The Bangkok Declaration is a political compromise. On the one hand, the Declaration stresses the "universality, objectivity and non-selectivity of all human rights" and that "no violation of human rights can be justified." HUMAN RIGHTS AND INTERNATIONAL RELATIONS IN THE ASIA-PACIFIC REGION, supra note 7, at 204-05. On the other hand, the Declaration declares that while "human rights are universal in nature, they must be considered in the context of a dynamic and evolving process of international norm-setting, bearing in mind the significance of national and regional particularities and various historical, cultural and religious backgrounds." Id. The Declaration also emphasizes respect for sovereignty, territorial integrity and non-interference in the internal affairs of others. Id. Reflecting the more assertive stance of the thirty-plus Asian states that adopted the Declaration without a vote, the Declaration objects to the politicization of human rights, double standards in the application of rights, and the tendency among Western states to privilege civil and political rights over economic, social and cultural rights. Moreover, it rejects a confrontational approach to human rights issues in favor of cooperation based on equality and respect. The Bangkok Declaration, along with the statements of Asian Governments at the Vienna World Conference on Human Rights in 1993 and the Asia-Pacific Non-Governmental Organizations' response to the Bangkok Declaration, can be found in Human Rights and INTERNATIONAL RELATIONS IN THE ASIA-PACIFIC REgion, supra note 7. After declaring the universal nature of human rights to be beyond question, the 1993 Vienna Declaration adopted by the General Assembly adds: "While the significance of national and regional particularities and various historical, cultural and religious backgrounds must be borne in mind, it is the duty of States, regardless of their political, economic and cultural systems, to promote and protect all human rights and fundamental freedoms." Thus, despite the difference in tone, both Declarations compromise universalism by emphasizing contextual factors. Nevertheless, the Bangkok Declaration was seen as a relativist attack on universalism whereas the Vienna Declaration has generally been portrayed as a victory for universalism. See, e.g., Christina M. Cerna, Universality of Human Rights and Cultural Diversity: Implementation of Human Rights in Different Socio-Cutural Contexts, 16 HUM. RTs. Q. 740, 741-42 (1994); THE VIENNA DECLARATION (June 25, 1993), available at http://www.hri. ca/vienna+5/vdpa.shtml (last visited Nov. 5, 2003). 
Asia or Africa. No one claims torture as part of their cultural heritage." However, he then went on to point out that "the hard core of rights that is truly universal is perhaps smaller than we sometimes like to pretend." 49 Put differently, while there are areas of agreement about human rights, they represent non-issues. We hardly needed the human rights movement to confirm that murder is bad. No one in Asia or anywhere else in the world denies that. Indeed, if by murder one means wrongful killing, then it is by definition bad. As noted, there are many rights such as the right to be free from discrimination that people agree are good things when stated at very high level of abstraction. But agreement at this level of abstraction is not helpful in resolving most pressing social issues. As a result, there are many controversial human rights issues for which there is no universal agreement including what counts as discrimination. There is even considerable disagreement over what counts as murder as opposed to justified self-defense, euthanasia, or other excusable or morally less culpable killings. Whether capital punishment is permissible or itself a violation of human rights remains hotly contested.

Even within a relatively homogenous setting such as Europe, significant variations in the content, justification, interpretation, and implementation of rights forced the European Court of Human Rights (ECHR) to create the margin of appreciation doctrine. ${ }^{50}$ Neither the legislative history of the European Convention on Human Rights nor the Convention itself mentions the margin of appreciation. Nevertheless, the ECHR needed the doctrine to accommodate national diversity and to obtain sufficient elbow-room to avoid having to strike down national laws and thus run the risk of incurring the wrath of member states and undermining support for the ECHR. The need for a margin of appreciation doctrine is all the more pressing once one moves beyond the borders of the relatively homogenous, wealthy, liberal-democratic Europe into the broader international arena characterized by greater cultural, religious, political, and economic diversity. ${ }^{51}$

48. HUMAN RIGHTS AND INTERNATIONAL RELATIONS IN THE ASIA-PACIFIC REGION, supra note 7 , at 244 .

49. Id.

50. See Howard Charles Yourow, The Margin of APPRECIATION DoctRine IN THE DYNAMICS OFEUROPEAN HUMAN RIGHTS JURISPRUDENCE (1996). Although Council of Europe member states share a Judeo-Christian tradition, democracy, mixed-market economies and legal systems based on rule of law, the degree of homogeneity has decreased with the entrance of Central and Eastern European states in recent years. Whether this will lead to greater invocation of the margin of appreciation doctrine or to its curtailment as the ECHR seeks to reinforce the norms and standards of the original core members by imposing them on new members remains to be seen.

51. As discussed below, the margin of appreciation may be supported on moral/normative and/or pragmatic (strategic, realpolitik) grounds. Not everyone who accepts the practical necessity of the doctrine will believe that it is morally justified. One concern is that accepting a margin of appreciation doctrine might lead to a lowest common denominator approach and thus devalue rights. Even if a margin of appreciation approach is adopted, we should not expect the same degree of success in interpreting and implementing rights outside the E.U. context. 
Such diversity undermines similar attempts to sidestep the universalism problem by arguing for a pragmatic consensus on human rights issues or by holding out hopes for the emergence of an overlapping consensus. ${ }^{52}$ The pragmatic or overlapping consensus quickly breaks down once one moves beyond the feel-good discussions about the desirability of the broad wishlist of rights contained in human rights documents to the difficult issues of the justifications for such rights and how they are interpreted and implemented in practice. ${ }^{53}$ Undeniably, there is greater acceptance of the general idea of human rights than in the past and even more agreement among more countries and people about particular human rights and how they are to be interpreted and implemented. There is also good reason to believe that the scope of agreement will increase over time. Nevertheless, there is still ample room for reasonable people to disagree over the content, justification, interpretation, and implementation of rights.

Ironically, the very success of the human rights movement has led to inconsistencies in human rights law, thereby undermining the pretense of universalism founded on a belief in uniform decisions across a variety of contexts. The ever-expanding corpus of rights law includes international treaties, customary international law, regional laws and domestic constitutions and laws. A single right may be covered in all of these different bodies of law, with each body of law defining the right in somewhat different ways or subjecting the right to different limitations. A growing number of entities are charged with interpreting and applying this ever-expanding corpus of human rights law, including international courts, treaty committees, special rapporteurs, regional courts and committees, domestic courts, human rights commissions and ombudsmen. The proliferation of disparate entities interpreting various types of law relating to human rights has resulted in diverse interpreta-

Not only is the range of diversity much greater internationally than within Europe, but international human rights bodies lack the ECHR's mandate to impose legally binding decisions on states.

52. See, e.g., Sumner Twiss, A Constructive Framework for Discussing Confucianism and Human Rights, in CONFUCIANISM AND HUMAN RIGHTS 27-53 (Wm. Theodore de Bary \& Tu Weiming eds., 1998). The frequency with which rights advocates optimistically appeal to Rawls' notion of an overlapping consensus is somewhat bewildering given that it has not even proved possible to achieve on a wide range of rights issues in its place of origin, the United States.

53. Randall P. Peerenboom, The Limits of Irony: Rorty and the China Challenge, 50 PHIL. E. \& W. 56 (2000). See also Charles Taylor, Conditions of an Unforced Consensus on Human Rights, in THE EAST ASIAN CHALLENGE FOR HUMAN RIGHTS, supra note 7, at 124. Taylor suggests that it might be possible to achieve at least some agreement on certain norms of conduct such as genocide, murder, torture and slavery. Id. However, he is less confident about reaching an overlapping consensus on the underlying values that justify such norms. Id. at 125 . In any event, universalists who are moral realists will not be happy resting their claims for rights on the fact of universal consensus among states. After all, one of their arguments against the relativists is that even if all states at one time endorsed slavery or human sacrifices, such endorsement would not make the practices of slavery or human sacrifices right. Moral realist animal protectionists may believe we should all be vegetarians. 
tions of the same right and differences in outcomes in cases with similar facts. ${ }^{54}$

The nature of international law and the international human rights regime further undermines universality. When ratifying treaties, states may limit their obligations to reflect local traditions and values by imposing reservations. ${ }^{55}$ Moreover, in most instances, states are primarily responsible for the implementation of rights. Few treaties allow individuals to raise claims in an international forum, and when they do, they generally require that individuals exhaust their domestic remedies first. ${ }^{56}$ Perhaps most importantly, the international human rights regime has limited enforcement powers. Treaties generally only authorize promotional activities, monitoring, and supervision through the review of country reports submitted periodically by the member states. ${ }^{57}$ As a result, public censure or shaming is frequently the most serious

54. THE JuRisprudence of Human Rights LaW: A COMPARATIVE INTERPRETIVE APPROACH (Theordore S. Olin et al. eds., 2000). It should be noted that many of the pronouncements of these entities are non-binding. See also Douglass Lee Donoho, Autonomy, Self-governance, and the Margin of Appreciation: Developing A Jurisprudence of Diversity Within Universal Human Rights, 15 EMORY INT'L L. REV. 391, 432-33 (2001) ("A poorly rationalized mixture of ill-defined mandates, circumscribed powers, cumbersome mechanisms, and often overlapping substantive norms generally clouds the potential role of these institutions in developing the meaning of rights. Unfortunately, the international human rights system is generally characterized by a multiplicity of non-authoritative interpretative sources.").

55. See Engle, supra note 8, at 294-302 (reviewing reservations of Islamic states with respect to the Convention on the Elimination of All Forms of Discrimination Against Women [hereinafter CEDAW], including Art. 2 (establishing a policy for eliminating discrimination the reservation made is often in its entirety), Art. 13(a) (the right to family benefits and inheritance); Art. 15(4) (the rights of movement and domicile); Art. 16(a) (the right to enter marriage); Art. 16(c) (rights and obligations during marriage); Art. 16(f) (rights and obligations on dissolution of marriage); and 16(h) (the right to own property and to contract)).

56. The Optional Protocol to the International Covenant on Civil and Political Rights, G.A. Res. 2200A, U.N. GAOR, 21 st Sess., U.N. Doc A/6316 (1966), 999 U.N.T.S. 171 (entered into force Mar. 23, 1976) [hereinafter ICCPR], the Optional Protocol to CEDAW, G.A. Res. 54/4, U.N. G.A. Res., 54th Sess., U.N. Doc A/54/49 (1999), 38 I.L.M. 763 (entered into force Dec. 22, 2000) and the Convention Against Torture and other Cruel, Inhuman or Degrading Treatment or Punishment, G.A. Res. 39/46, 39 U.N. G.A. Res., 39th Sess., U.N. Doc. A/39/46 (1984), 1465 U.N.T.S. 85 (entered into force June 26, 1987) allow for individual complaints upon consent of the member states. In addition, the Inter-American and European regional systems allow for individual complaints.

57. In addition, human rights bodies often may issue general comments or interpretations. From time to time, committees such as the ICCPR's Human Rights Committee [hereinafter HRC] will try to bootstrap their claims to be able to issue binding interpretations. Thus the HRC has claimed the authority to declare certain reservations invalid such that the reserving party assumes all of the obligations of the treaty as if the reservations were not made. See General Comment No. 24, Hum. Rts. Comm., at 18, U.N. Doc. CCPR/C/21/Rev./Add.6(1994). However many states do not consider the HRC position binding.

In any event, such international bodies face many of the same issues as domestic courts in deciding rights issues. Outcomes are determined by the judicial theories and interpretative methodologies of the decision-maker (e.g., original intent, plain meaning, purposeoriented approaches). Decision-makers must also weigh the rights and interests of individuals against the rights and interests of other individuals or the interests of the public. In so doing, 
sanction available. ${ }^{58}$ In the final analysis, then, states have a

they must also consider jurisprudential issues such as the development of defensible standards and the legitimacy of the institution. See Donoho, supra note 54, at 441 . Unlike domestic institutions, they are also more likely to encounter a wider diversity of values, beliefs and opinions. In addition, they must constantly keep in mind the fundamental difference that member states may withdraw from the treaty if the decisions are not to their liking.

58. This is not to deny that shaming may be effective in some circumstances. Clearly, the human rights regime has had some positive affect in some instances with respect to some issues even given its limited enforcement tools. Muntarbhorn summarizes several of the positive benefits of participating in the international human rights regime, despite its limited powers of enforcement:

First, the standards expounded by these treaties help to promote law, policy and practical reforms by offering an international barometer to test national standards. Second, the country is obliged to prepare and send periodic national reports on how it is implementing the treaties to the various international treaty bodies charged with monitoring the implementation of these treaties at the national level. This helps to provide transparency and channels for eliciting international recommendations to help the local reform process. Third, the information and data gathered to prepare such national reports help to build a database system useful for planning and implementation. Fourth, the process of national report preparation may bring together both governmental and non-governmental actors to enhance cross-sectoral cooperation, which can assist in the implementation of the Rule of Law and human rights. Fifth, the opportunity of liaising between different sectors of the community to implement international standards at the national and local levels is an empowering process which may lead to the enhancement of cooperation through joint actions. In this context, there are avenues to share local experiences and wisdom which can provide value-added to the international perspective.

Vitit Muntarbhorn, The Rule of Law and Aspects of Human Rights in Thailand: From Conceptualization to Implementation?, in ASIAN DISCOURSES OFRULE OFLAW: THEORIES AND IMPLEMENTATION OF RULE OF LAW IN TWELVE ASIAN COUNTRIES, FRANCE AND THE U.S. (Randall Peerenboom ed., 2004).

In general, the human rights movement has altered public discourse and provided a moral foundation for criticisms of governments that abuse rights. A country's ratification of a human rights treaty generally strengthens the hand of domestic and international rights advocates. Thus, in the long term, the human rights situation may improve. Nevertheless, signing a treaty by no means ensures compliance. The reality is that despite the proliferation of human rights treaties, rights abuses remain widespread. A study of 178 countries from 1976 to 1993 found that signing the ICCPR or even the Optional Protocol allowing individuals to raise complaints had no impact on state's actual behavior after controlling for other factors known to affect human rights implementation. See generally Linda Camp Keith, The United Nations International Covenant on Civil and Political Rights: Does It Make a Difference in Human Rights Behavior?, 36 J. PEACE RES. 95 (1999). Overall human rights protection among member states was no better than among non-member states, all else being equal. Id. Another quantitative study examining compliance with respect to torture, genocide, fair trials, civil liberties, and women's political equality in 166 countries found similar results. Although countries that ratify human rights treaties usually have somewhat better compliance ratings than countries that do not (without controlling for other factors), noncompliance is rampant. See generally Oona A. Hathaway, Do Human Rights Treaties Make a Difference?, 111 YALE L.J. 1935 (2002). Moreover, countries with the worst human rights records sometimes have higher ratification rates than countries with better human rights records. See id. at 1978. In some cases, treaty ratification is associated with worse human rights ratings, leading the author to conclude that the "relatively costless step of treaty ratification may thereby offset pressure for costly changes in policies." See id. at 1941. 
large role in defining what rights mean within their jurisdictions and in translating often-abstract notions into concrete practices through implementation.

Indicative of the politicized nature of the first round of the debates, opponents of Asian values frequently refused to acknowledge a reasonable margin of appreciation and the many reasons for it. Part of the problem was the lack of a truly comparative framework. Both sides relied on overly simplistic constructs of "the West" and "Asia"/"the East." 59 While Asianvalues opponents were quick to criticize defenders of Asian values for constructing a fictive Asia, they were no less guilty of constructing an overly unified and idealized "West." Opponents of Asian values oftentimes seemed unaware of the variation, even within Western states. They took at face value the long list of rights in international law documents or emphasized idealized accounts of rights or the lofty aspirational normative visions of philosophers, ignoring or downplaying the failure to implement such rights in practice or the many critiques of, and doubts about, rights in the West. ${ }^{60}$ They also ignored the historical evolution of rights and how the United States and other Western countries only recently have begun to take many rights seriously. ${ }^{61}$ Some

Empirical studies have demonstrated that a number of substantive factors are more important for the protection of human rights than signing international treaties. One such study found that civil war exercised the most impact, followed by economic development, democracy, population size, international war, military control and the lack of British colonial influence. See Steven Poe et al., Repression of the Human Right to Personal Integrity Revisited: A Global Cross-National Study Covering the Years 1976-1993, 43 INT'LSTUD. Q. 291, 310 (1999). The same study also found that leftist regimes were less likely to repress personal integrity than nonleftist regimes. Id. See also Conway Henderson, Conditions Affecting Use of Political Repression, 35 J. CONFLICT RES. 120 (1991) (democracy, inequality and economic growth were statistically significant predictors of political repression, though level of economic development was not); Neil J. Mitchell \& James M. McCormick, Economic and Political Explanations of Human Rights Violations, 40 WORLD POL. 476, 497 (1988) (countries with higher levels of economic well-being have consistently albeit modestly better human rights records that those that do not); Frank B. Cross, The Relevance of Law in Human Rights Protection, 19 INT'LREV. LAW \& ECON. 87, 93 (1999) (finding that judicial independence is significant with respect to the protection of political rights and search and seizure even after controlling for wealth and other factors, but finding that federalism and separation of powers were not significant and the presence of constitutional provisions regarding search and seizure seems to have no real-world significance).

59. As discussed infra, the issue is not that East and West are constructs, but that they have been overly simplistic and oftentimes misleading constructs.

60. See Kenneth Morris, Western Defensiveness and the Defense of Rights: A Communitarian Alternative, in NEgOTIATING CULTURE AND HUMAN RIGHTS, supra note 7 (pointing out that many of the arguments of advocates of Asian values have their Western counterparts).

61. As Richard Posner notes about the United States:

There was surprisingly little actual enforcement of constitutional rights in the 1950s. A large proportion of criminal defendants who could not afford a lawyer had to defend themselves; the appointment of lawyers to represent indigent criminal defendants was not routine. Many state prisons and state insane asylums were hellholes, and to their inmates' complaints the courts turned a deaf ear. The right of free speech was narrowly interpreted, the better to crush the Communist 
implicitly or explicitly relied on the frequently extreme practices of the United States as a benchmark. But the United States is an outlier even within Western liberal democracies on many rights issues from free speech to the rights of suspected criminals. ${ }^{62}$ In short, the reality of Asian states frequently was compared to an idealized self-image of "the West," and in some cases, the United States.

Conversely, government spokespeople often stretched the margin of appreciation well past the breaking point. Guilty of widespread abuses of human rights not defensible under any standards, including forced labor, rape and murder by the military, Myanmar officials cynically invoked Asian values to ward off criticism at the Bangkok conference, arguing that "Asian countries with their own norms and standards of human rights, should not be dictated [to] by a group of other countries who are far distant geographically, politically, economically and socially." 63

The debates could have been greatly sharpened by moving beyond grand statements, posturing polemics, and inflamed rhetoric to concrete issues bolstered by broad comparative, empirical, and historical studies of actual cases and events that demonstrate where exactly different countries draw the lines on human rights issues, the reasons (cultural, religious, political, economic, legal, and military) for the outcomes, and how the outcomes and rationales have changed over time as the context has changed. ${ }^{64}$ Such an approach would clarify just how extensive the overlapping consensus actually is. It would also identify common ground and rationales that could be useful

Party U.S.A. and protect the reading public from Henry Miller. Police brutality was rampant, and tort remedies against it ineffectual. Criminal sentencing verged on randomness; in some parts of the country, capital punishment was imposed with an approach to casualness. In practice the Bill of Rights mostly protected only the respectable elements of society, who did not need its protection. ... There were almost no effective legal protections of the environment. Every variety of invidious discrimination was common in employment, and there were virtually no legal remedies for it.

POSNER, supra note 36, at 197-98.

62. See Discussion: Asian Values, 41 KOREA J., Autumn 2001, at 246 (noting that "Western values" is often over-generalized, and suggesting that freedom and individualism are valued more highly in the United States than in Europe). Just as we need a more systematic empirical basis to support claims about Asian values, so do we with respect to "Western values."

63. CHRISTIE \& ROY, supra note 8, at 100. As Christie wrote the chapters on Southeast Asia and Roy the chapters on Northeast Asia, I will specify the author accordingly, in part because Christie seems more hostile to the idea of Asian values and Roy more neutral in his presentation.

64. As rights are increasingly the medium through which different factions struggle for power, a focus on legal cases reveals much about who has power within a society. Because cases generally have legal opinions and often have minority dissents, one can also get a sense of the diversity of views within a society. However, because not all issues will necessarily be resolved through the formal legal system, any such empirical study would also need to expand its scope to include important social and political events that do not make it to court and other issues dealt with through informal mechanisms. 
in expanding the overlapping consensus. And in some cases it would demonstrate that overlapping consensus is not likely, or at least not likely given the current circumstances.

As we have seen, some Asian governments argue that the hard core of universal rights is extremely limited. To be sure, there is little disagreement that some acts are bad, such as torture, disappearances, genocide and slavery. However, little disagreement does not mean no disagreement, even in these seemingly uncontroversial cases. Until recently, Israel permitted some forms of torture, justified on national defense grounds. ${ }^{65}$ Philosophers love to debate the merits of torturing a terrorist who refuses to reveal the location of a deadly bomb that will wipe out the lives of thousands of innocent people. They even debate whether it would be permissible to torture or kill an innocent person if that were the only way to get the terrorist to reveal the location of the bomb. ${ }^{66}$ While such arguments were easily dismissed in the past as the harmless musings of academics isolated in their ivory tower, the September 11 attacks on the United States and the ongoing retaliatory war on terrorism have given rise to public debates about the permissible use of torture in national emergencies. ${ }^{67}$ But even before September 11 , there were many disagreements about what exactly counts as torture, or its ex post cousin, cruel and unusual punishment. Does torture include mental suffering and degrading

65. See Public Committee against Torture, in Israel v. Israel, HC 5100/94, Pub. Comm. Against Torture in Israel v. The State of Israel et al. (Sept. 6, 1999), available at http://www. derechos.org/human-rights/mena/doc/torture.html (last visited Nov. 5, 2003), reprinted in 38 I.L.M. 1471 (1999) (translating High Court of Justice's ruling that the Israeli Security Services could no longer use physical force in interrogations of suspected terrorists absent legal statutory provision granting GSS power to use such methods). The use of physical force included violent shaking which can lead to fainting, vomiting, intense head pain, urinating without control, and, at least in one case, death; the "Shabach position" where suspects are forced to sit in a low chair with their hands tied behind their back and head forced downward and covered in a hood while loud music is blasted inches from their ears; the frog crouch, where the suspect must crouch on tip-toes for five-minute intervals; and sleep deprivation. Jason Greenberg, Note, Torture of Terrorists in Israel: The United Nations and the Supreme Court of Israel Pave the Way for Human Rights to Trump Communitarianism, 7 ILSA J. INT'L \& COMP. L. 539 (2001); Ardi Imseis, Comment, 'Moderate' Torture On Trial: Critical Reflections on the Israeli Supreme Court Judgment Concerning the Legality of General Security Service Interrogation Methods, 19 BERKELEY J. INT'L LAW 328 (2001). Even before the recent violent clashes in Israel, critics cautioned that the Supreme Court's decision was hardly a watershed for the human rights of Palestinians and other potential enemies of the state. Id. In its opinion, the Court invited Parliament to pass legislation overturning the decision, and also left open the possibility of use of such methods in certain circumstances where there was really a "ticking bomb." Deborah Sontag, Israel Court Bans Most Use of Force in Interrogations, N.Y. TIMES, Sept. 7, 1999, at A1. Lawyers also cited a list of ongoing problems, including lack of access to their clients held in custody and refusals to grant travel permits and family reunification requests on security grounds. Id. See also Dan Izenberg, Ten-year Battle Against Brutality Ends in Victory, JERUSALEM POST, Sept. 10, 1999, at 1B.

66. See Alan Gewirth, Are There Any Absolute Rights?, 31 PHIL. Q. 1 (1981).

67. See ALAN DERSHOWITZ, WHY TERRORISM WORKS: UNDERSTANDING THE THREAT, RESPONDING TO THE CHALLENGE (2002). 
treatment? Is interrogation for six consecutive hours in a heavily air-conditioned room torture? How about twelve hours? Twenty-four hours? Fortyeight hours? Is caning, as allowed in Singapore and previously in Europe, but now prohibited by the ECHR, cruel and unusual punishment? ${ }^{68}$ Is cutting off the hand of a thief cruel and unusual punishment? What about capital punishment? Is incarceration for long periods in prisons where convicts may be subject to rape or violence from other prisoners, as occurs in United States prisons, cruel and unusual $?^{69}$ Is it cruel and unusual to keep people waiting on death row for more than five years? Two years? One year? Does it matter if the reason for delay is that the legal representatives for the inmate keep appealing $?^{70}$ Of course, even assuming an overlapping consensus with respect to the meaning and reprehensibility of torture and cruel and unusual punishment (would anyone deny that being shocked with cattle prods or burnt with cigarettes is torture?), in practice torture and cruel and unusual punishments remain widespread and not just confined to Asian countries. Granted, states often deny the existence of torture or claim that it is not sanctioned by the state and that the state actors who commit torture are prosecuted and punished. However, in many cases, there is little enforcement, and few are subject to prosecution. $^{71}$

68. See Tyrer v. United Kingdom, 26 Eur. Ct. H.R., (ser. A), at 1 (1978).

69. For some truly harrowing accounts of sexual abuse of inmates by other prisoners and guards, see Cheryl Bell et al., Rape and Sexual Misconduct in the Prison System: Analyzing America's Most "Open" Secret, 18 YALE L. \& POL' Y REV. 195 (1999); Martin A. Geer, Human Rights and Wrongs in Our Own Backyard: Incorporating International Human Rights Protections Under Domestic Civil Rights Law-A Case Study of Women in the United States Prisons, 13 HARV. Hum. RTS. J. 71 (2000). See also Carrigan v. State, 957 F. Supp. 1376, 1382 (D. Del. 1997) (holding against female inmate raped by guard because the existence of only a few prior incidents of misconduct was insufficient to show knowledge of substantial risk of serious harm).

70. For a discussion of case law on this point from a variety of countries as well as jurisprudence from UN human rights bodies, see Markus G. Schmidt, The Death Row Phenomena: A Comparative Analysis, in THE JURISPRUDENCE OF HUMAN RIGHTS LAW: A COMPARATIVE INTERPRETIVE APPROACH, supra note 54, at 47-72. The study shows a wide range from countries that find capital punishment itself to be cruel and unusual to other states that do not find any length of stay on death row cruel and unusual.

71. Amnesty International, United States of America-Rights for All, 2-3 (1998), available at http://web.amnesty.org/library/Index/ENGAMR510361998!open\&of=ENG-USA (last visited Nov. 5, 2003):

There is widespread and persistent police brutality across the USA. Thousands of individual complaints about police abuse are reported each year. . . Police officers have beaten and shot unresisting suspects; they have misused batons, chemical sprays and electro-shock weapons; they have injured or killed people by placing them in dangerous restraint holds.... Common forms of ill-treatment are repeated kicks, punches or blows with batons or other weapons, sometimes after a suspect has already been restrained or rendered helpless. There are also complaints involving various types of restraint holds, pepper (OC) spray, electroshock weapons and firearms. ... [V]ictims include not only criminal suspects but also bystanders and people who questioned police actions or were involved in minor disputes or confrontations.

Nevertheless, successful prosecutions of police for physical abuse are rare. 
Other human rights issues are even more contentious. One of the main criticisms of Asian governments is that they invoke a cultural preference for stability over freedom to justify broad national security laws, extensive limitations of civil and political rights, and the derogation of criminal procedure and due process rights. There is no doubt that in some cases Asian governments do exaggerate the threat to national security and social order, and that many security laws are broadly drafted and kept on the books even after the threat for which they were created no longer exists. For instance, in Singapore, the Internal Security Act, inherited from the British and justified initially to prevent communist agitation, remains in effect, thereby allowing police to arrest and detain, without trial, anyone deemed to be "acting in a manner prejudicial to the security of Singapore."72 Yet it is also true that many Asian states are less stable than mature Western liberal democracies. Moreover, while human rights may be destabilizing everywhere, they may be more destabilizing in Asia. In China, for instance, the ruling regime has yet to develop political institutions for adequately addressing human rights claims. Nor is there a reasonably coherent theoretical framework that incorporates rights and yet is consistent with the regime's norms. ${ }^{73}$ It also appears the majority of citizens in different countries assign a different value to stability and order versus freedom. ${ }^{74}$

72. CHRISTIE \& RoY, supra note 8, at 60 (quoting Asia Week, June 15, 1985, at 20).

73. Whether out of traditional Confucian concerns for harmony and consensus or for more mundane political reasons, the Singaporean government has clearly tried to encourage disgruntled parties to seek compromise solutions through the political process rather than pressing potentially divisive rights claims in court. When an opposition party sought to set up a Malay rights group in 1997, a government spokesperson criticized the move as being unhelpful and dangerous to racial harmony, and suggested that it might lead to more vocal claims by other groups, such as the Chinese and Indian for special protections. The government argued that developing programs to tackle social problems like drug abuse and the rising divorce rate would be more constructive than "rights talk." The government also discouraged rights litigation when a controversy erupted over the wearing of tudung (Muslim headscarf) during a time when race relations were particularly delicate. As Singaporean constitutional law expert Thio $\mathrm{Li}$-ann notes, the dispute raised important constitutional issues regarding the scope of religious freedom. However, the Prime Minister urged the parents of the schoolgirls be pragmatic and put their daughter's interests in receiving an education first by sending them back to school without the headscarves, which he argued were not religiously mandated. Despite the government's preference for a pragmatic approach based on dialogue rather than more adversarial litigation, it has indicated that it will be abide by a judicial ruling if the issue goes to court. Thio Li-ann, Lex Rex or Lex Rex? Competing Conceptions of Rule of Law in Singapore, in ASIAN DISCOURSES OF RULE OF LAW: THEORIES AND IMPLEMENTATION OF RULE OFLAW IN TWELVE ASIAN COUNTRIES, FRANCE AND THE U.S., supra note 58.

74. See Susan Sim, Human Rights: Bridging the Gulf, STRAITS TIMES (Singapore), Oct. 21,1995 , at 32. A survey of academics, think tank experts, officials, businesspeople, journalists, and religious and cultural leaders found significant differences between Asians and Americans. Id. The former chose an orderly society, harmony, and accountability of public values, in descending order, as the three most important societal values. Id. In contrast, the Americans chose freedom of expression, personal freedom, and the rights of the individual. See also Bridget Welsh, Attitudes Toward Democracy in Malaysia, 36 ASIAN SURV. 882 (1996) (reporting that a survey of Malaysians in 1994 found that the majority were willing to limit 
To be sure, Western governments have also enjoyed wide latitude in determining when a threat is sufficient to justify the derogation of criminal procedure and due process rights. In upholding the British government's derogation of due process rights as necessary to control civil strife in Northern Ireland, the ECHR stated:

It falls in the first place to each Contracting State, with its responsibility for "the life of [its] nation," to determine whether that life is threatened by a "public emergency" and, if so, how far it is necessary to go in attempting to overcome the emergency. By reason of their direct and continuous contact with the pressing needs of the moment, the national authorities are in principle in a better position than the international judge to decide both on the presence of such an emergency and on the nature and scope of derogations necessary to avert it. In this matter, Article 15(1) [of the European Human Rights Convention] leaves those authorities a wide margin of appreciation.... It is certainly not the Court's function to substitute for the British Government's assessment any other assessment of what might be the most prudent or most expedient policy to combat terrorism. ${ }^{75}$

The Court also noted that it must not base its decision on twenty-twenty hindsight, but must consider the government's decisions and actions in light of the circumstances at the time. A wide margin of appreciation does not mean unlimited discretion, of course. Furthermore, a state's derogation may not extend to certain rights, such as the right to life or freedom from slavery and discrimination. ${ }^{76}$ Nevertheless, it is striking that the ECHR allowed dero

democracy, particularly when social order was threatened, and that fears of instability and Asian values led to limited support for democracy; also noting that respondents were willing to sacrifice freedom of speech in the face of threats to social order). For several studies that show the high value assigned to order in China and limited demand for democracy, see RANDALLP. PEERENBOOM, CHINA's LONG MaRCH TOWARD RULE OF LAW 53-56 (2002). Similarly, in Taiwan, while seventy-five percent of respondents in a 1999 study indicated that democracy was important to them in "their personal lives," a 1998 survey found that fifty-five percent of respondents believed developing the economy was more important than establishing democracy, with just over thirty percent giving the edge to democracy. Id. Some forty-percent of the sample initially indicated that the economy was more important than democracy and forty percent indicated that the two were equal. Id. When this last group was forced to choose, sixtythree percent opted for the economy. Id. See Sean Cooney, The Application, and Non-application, of Rule of Law Principles in Taiwan, in THE CONSTRUCTION AND DECONSTRUCTION OF RULE OF LAW IN ASIA: THEORIES AND IMPLEMENTATION OF RULE OF LAW IN TWELVE ASIAN COUNTRIES, FRANCE AND THE U.S., supra note 58.

75. Ireland v. United Kingdom, 25 Eur. Ct. H.R., (ser. A), para. 207, 214 (1978).

76. International Covenant on Civil and Political Rights, G.A. Res. 2200A, U.N. GAOR, Supp. No. 16, at 52, U.N. Doc. A/6316 (1966), available at http://www1.umn.edu/humanrts/ instree/b3ccpr.htm (last visited Sept. 18, 2003) [hereinafter ICCPR]. Article 4 of the ICCPR provides that: 
gation in all of the cases it has decided, with the exception of the Greek Colonels case where the entire government was suspended by a military takeover (it bears noting that Greece then proceeded to denounce the decision and withdraw from the Convention, demonstrating the practical limits of international human rights law). In the Ireland case, the Court upheld the detention of a member of the Irish Republican Army without trial for five months. ${ }^{77}$

It is much easier to be bold in calling for the protection of individual rights and opposing measures aimed at ensuring stability when it is someone else that will suffer the consequences. The United States and Western European countries are stable places and remain so even after the September 11 attacks. However, many Asian countries including China, Myanmar, Cambodia, Indonesia, Nepal, the Philippines, Thailand, and Malaysia are less stable. Some of these countries are torn by civil strife, racked by ethnic divisions, or actively engaged in long running battles with terrorists. ${ }^{78}$ People in the United States and Western Europe have a comfortable life; many in Asia are living precariously on the edge and cannot afford social chaos. Amnesty International has claimed massive human rights violations in Nepal by both the military and Maoist guerrillas, including the killing and kidnap-

In time of public emergency which threatens the life of the nation and the existence of which is officially proclaimed, the States Parties to the present Covenant may take measures derogating from their obligations under the present Covenant to the extent strictly required by the exigencies of the situation, provided that such measures are not inconsistent with their other obligations under international law and do not involve discrimination solely on the ground of race, colour, sex, language, religion or social origin.

Id However, derogation is not allowed with respect to articles 6 (right to life), 7 (torture, cruel and unusual punishment), 8 (slavery), 11 (no jail for failure to pay debt), 15 (nullem crime sine lege), 16 (recognition as person before law) and 18 (freedom of though, conscience and religion). Id.

77. Compare Brogan v. United Kingdom, A145-B Eur. Ct. H.R., (ser. A), at 117 (1988) (holding that detention of suspected terrorists for up to seven days without being charged violated the Art. 5(3) requirement that those arrested or detained be brought promptly before a judge or other judicial officer). The state argued that it needed more time given the difficulty of obtaining evidence, and that in thirty-nine of eighty-six such cases, the extra time led to a charge of terrorism. Id. The Court, noting that there was no state of emergency declared at the time, held that anything over four days was too long. Id. One judge dissented, observing that in a democratic country, presumably the people know best how to draw the proper balance between the rights of individuals and safety of others in society. Id. The United Kingdom then lodged a derogation for public emergency. $I d$. The Court upheld the derogation and detention for more than six days in Brannigan and McBride v. U.K, 258-B Eur. Ct. H.R., (ser. A) (1993), available at http://hudoc.echr.coe.int/Hudoc2doc/HEJUD/sift/404.txt (last visited Nov. 5, 2003).

78. For a list of conflicts in various Asian countries, see Richard Klein, Cultural Relativism, Economic Development and International Human Rights in the Asian Context, 9 TOURO INT'L L. REV. 1 (2001). In February 2003, one day after Secretary of State Colin L. Powell visited Beijing and a week before China's national legislature opened its annual session, two bombs exploded in cafeterias at two of China's leading universities, injuring nine people. See John Pomfret, Explosions Rock China's Top 2 Universities, WASH. POST FOREIGN SERV., Feb. $25,2003$. 
ping of civilians, torture of prisoners, and destruction of property. ${ }^{79}$ In defense of the government's suspension of constitutional freedoms and harsh actions, Nepal's Prime Minister declared: "You can't make an omelette without breaking eggs. We don't want human rights abuses but we are fighting terrorists and we have to be tough." ${ }^{80}$ While the annual per capita income in the Nepal is less than $\$ 200$, the government is spending ten million dollars a week on fighting the Maoists. ${ }^{81}$ Furthermore, tourism revenues have all but disappeared and foreign investment and exports are down by ninety percent. ${ }^{82}$

When the United States was less stable, most notably during the war years in the 1920s and 1940s, the government's response was to curtail free speech and, during WWII, to lock up Americans of Japanese descent out of fear that they might be a threat to national security. ${ }^{83}$ In fact, the United States has regularly reacted to domestic instability in ways inconsistent with international standards of rights, ${ }^{84}$ including in its ongoing war on crime. ${ }^{85}$

79. Daniel Lak, Kingdom on the Brink of Catastrophe, S. CHINAMORNING POST, May 12, 2002 , at 7 .

80. Id.

81. Id.

82. Id.

83. See David Rabban, The First Amendment in its Forgotten Years, 90 YALE L.J. 514 (1981); Korematsu v. United States, 323 U.S. 214 (1944).

84. See Diane Wood, The Rule of Law in Times of Stress, 70 U. CHI. L. REV. 455, 460 (2003) (noting that Lincoln suspended habeas corpus during Civil War, approved by Congress; 2200 people were prosecuted under Espionage and Sedition Acts, with more than 1000 convicted during WWI; the right of habeas corpus was suspended and martial law imposed in Hawaii after Pearl Harbor; during the McCarthy era, the Supreme Court in Am. Communications Ass'n. v. Douds, 339 U.S. 3832, 288-89 (1950) permitted regulations requiring labor unions to sign an oath swearing they were not members of Communist Party and did not believe in the overthrow of the United States, and in Dennis v. U.S., 341 U.S. 494, 501 (1951) rejected "any principle of government helplessness in the face of preparation for revolution, which principle, carried to its logical conclusion, must lead to anarchy"); William E. Lee, "Security Review" and the First Amendment, 25 HARV. J.L. \& PUB. POL'Y 743 (2002) (noting that journalists who wanted to accompany American military personnel on U.S military cargo plans into Afghanistan to report on the "Operation Enduring Freedom" were required to accept certain conditions, including that they share their account with other media, not report the full names of military personnel, not report sensitive mission information such as altitude or route, and submit to a security of their report by military officials before publication); Richard Morin \& Claudia Deane, Belief Erodes in First Amendment, WASH. POST,, Sept. 3, 2002, at A15 (poll shows that forty-nine percent of the public thinks the First Amendment goes too far, up from thirty-nine percent in 2001, twenty-two percent in 2000).

85. See generally Amnesty International, United States of America-Rights for All 2-3 (1998), at http://web.amnesty.org/library/index/ENGAMR510541998 (last visited Sept. 18, 2003), (finding that police officers, prison guards, immigration and other officials regularly breach domestic and international laws and that authorities have failed to punish and prevent abuses, and that while the United States has used international human rights standards as a yardstick to judge other countries, the United States government policies and practices frequently ignore or fall short of the minimal standards required by the international community). See also Johan D. van der Vyver, Universality and Relativity of Human Rights: American Relativism, 4 BUFF. HUM. RTS. L. REV. 43, 71-72 (1998) (noting many ways in which United States is at odds with international legal standards, including continued reliance on death penalty, even for 
Even today, the United States, France, and other countries have rushed to curtail civil liberties and to tighten criminal laws in the wake of the September 11 terrorist attacks. ${ }^{86}$ In France, Parliament passed a law on public order without referring it to the Constitutional Council, ${ }^{87}$ perhaps because it contains at least one provision expressly not in conformity with the Council's past jurisprudence. The new legislation gives the police broad powers to search vehicles to fight crime, even though the Constitutional Council nullified an identical provision in a 1997 decision. ${ }^{88}$ The Council rejected the law on the ground that, by giving police virtually unlimited authority to search vehicles, the law failed to provide adequate controls on police activity and violated individual freedom. ${ }^{89}$

Meanwhile, the United States has passed a series of legislative acts and executive orders that greatly curtail civil liberties. ${ }^{90}$ Just one week after the September 11 attacks, Congress hurriedly passed a bill authorizing the President to use all necessary force against any organization or state found to have been involved in the planning or execution of terrorist acts in the United States. ${ }^{91}$ The bill also authorized the use of force against any state providing a safe haven to terrorist organizations that harm the United States. Other legislation expanded the government's authority to issue wiretaps and intercept and monitor written, oral, and electronic communication..$^{92}$ In a move much denounced by civil liberty groups, the Department of Justice

juveniles and the mentally impaired; limits on double jeopardy in that criminal suspects may be tried on both state and federal charges for the same facts; juveniles may be tried whereas international human rights standards provide that criminal suspects get the benefit of a lighter sentence if changes in the law reduce punishments after the crime is committed but before sentencing, while in the United States they are subject to the heavier punishment; and the failure to require the separation of unconvicted detainees from convicted prisoners). $C f$. JOHN RAYMOND COOK, ASPHALT JUSTICE: A CRITIQUE OFTHE CRIMINALJUSTICE SYSTEM IN AMERICA 14 (2001) (arguing that the current "get tough" on crime approach has failed miserably and calling for a comprehensive approach that puts more emphasis on rehabilitation by providing criminals an incentive to change their behavior while in prison and improve themselves).

86. See generally Joshua D. Zelman, Recent Developments in International Law: AntiTerrorism Legislation-Part One: An Overview, 11 J. TRANSNAT'L L. \& POL'Y 183 (2001); Philip Heyman, Civil Liberties and Human Rights in the Aftermath of September 11, 25 HARV. J.L. \& PUB. POL'Y 441 (2002); Neal K. Katyal \& Laurence H. Tribe, Waging War, Deciding Guilt: Trying the Military Tribunals, 111 YALE L. J. 1259 (2002).

87. Loi Relative À la Sécurité Quotidienne, Act n²001-1062, Nov. 15, 2001, J.O. n²66, Nov. 16, 2001.

88. Laurent Pech, The French Conception of Rule of Law, in ASIAN DISCOURSES OF RULE OF LAW: THEORIES AND IMPLEMENTATION OF RULE OF LAW IN TWELVE ASIAN COUNTRIES, FRANCE AND THE U.S., supra note 58.

89. See id.

90. See Zelman, supra note 86, at 185-90; Jordan J. Paust, Antiterrorism Military Commissions: Courting Illegality, 23 MICH. J. INT'LL. 1 (2001); Jordan J. Paust, Antiterrorism Military Commissions: The Ad Hoc DOD Rules of Procedure, 23 MICH. J. INT'L L. 677 (2002).

91. Military Force Authorization Bill, S. J. Res. 23, 10th Cong. (2001) (enacted).

92. See Uniting and Strengthening America by Providing Appropriate Tools Required to Intercept and Obstruct Terrorism Act of 2001, Pub. L. No. 107-56, S 201-225 (2001). 
issued an order permitting the monitoring of attorney-client communications between inmates in its custody and their lawyers. ${ }^{93}$ In one of the most controversial moves of all, President Bush signed an executive order that allows military tribunals to try non-citizens. ${ }^{94}$ Human rights groups and legal scholars have complained that the accused would not have a right to appeal, the public would not learn about the case until after the suspects were convicted and sentenced, and suspects could be detained indefinitely without conviction. ${ }^{95}$ The order appears to deprive the accused of the right of habeas corpus to challenge the decision to arrest in court, even though habeas corpus may be suspended only by Congress in times of invasion or rebellion. Moreover, the accused may be convicted and sentenced to life in prison or death if two-thirds of the panel agrees, even though military courts, under the Uniform Code of Military Justice, require unanimity in capital cases and provide for several stages of appellate review. Military courts also provide many due process rights, such as protection against double jeopardy and selfincrimination, not available to those hauled before the terrorist tribunals. Critics of these actions have noted that previously the United States imposed economic sanctions on Myanmar and criticized Egypt for holding trials by military tribunals, and complained about secret trials in China and Russia. In response to such criticisms, Vice President Cheney, sounding more like the conservative Chinese leader Li Peng than one of the leaders of the "Free World," stated: "These people are criminals illegally entering into the United States, killing our citizens. They do not deserve the same guarantees and safeguards that would be used for an American citizen going through the normal judicial process." 96

93. Prevention of Acts of Violence and Terrorism, 28 C.F.R. $\S 501.3$.

94. Robert A. Levy, Don't Shred the Constitution to Fight Terror, WALL ST. J., Nov. 20, 2001, at A18. Paust, supra note 81, at 677.

95. See, e.g., Warren Richey, How Long Can Guantanamo Prisoners Be Held?, CHRISTIAN SCI. MONITOR, Apr. 9, 2002, 1, 4 (quoting U.S. Deputy Assistant Attorney General John Yoo: "Does it make sense to ever release them if you think they are going to continue to be dangerous even though you can't convict them of a crime?").

96. See "Ta Kung Pao Accuses US of Violating Human Rights with Proposed Military Tribunals," FBIS-CHI-2001-1126, Nov. 26, 2001. See also Laura A. Dickinson, Using Legal Process to Fight Terrorism: Detentions, Military Commissions, International Tribunals, and the Rule of Law, 75 S. CAL. L. REV. 1407, 1433-34 (2002) (citing justifications for military tribunals that are eerily similar to claims by PRC officials for limiting rights, including that (i) trials take too long and cost too much and are a nuisance or danger when fighting terrorism; (ii) civilian judges and witnesses would be at risk; (iii) there is no need to protect the rights of terrorists; (iv) normal rules do not fit the circumstances - soldiers in the field can hardly be expected to read Bin Laden his Miranda rights; it is not possible to maintain the chain of custody for evidence out in the field and state secrets are involved; and (v) witnesses will use public trials to grandstand for political purposes). 
If there is anything universal, it would seem to be disregard for rights whenever there are real or perceived threats to stability and social order. ${ }^{97}$ Even allowing that the threat of terrorism is real in the United States, it would not seem to rise to the level of a public emergency that threatens "the life of the nation," as literally required under Article 4 of the ICCPR to justify the derogation of civil and political rights. ${ }^{98}$ Prior to September 11 , the U.S. State Department and Western rights organizations often criticized Asian countries for cracking down on dissidents, insurgents, terrorists, and others who threaten social order on the ground that the life of the nation was not at stake. The restrictions were perceived as required to keep the ruling regime in power but not arising from a threat to the nation as such. Yet surely the threats faced by many Asian countries are more serious than the threats currently faced by the United States. After all, it stretches credulity to suggest that isolated acts of terrorism, deplorable as they may be, could bring the world's mightiest military power to its knees-though they may succeed in causing a major change in the "life of the nation" if the government's repressive policies to combat terrorism erode the very liberties they are supposed to protect. In contrast, many Asian states, weakened by ethnic strife, economic crisis, and insurgent movements whose express purpose is to bring down the government, do confront challenges that could result in the overthrow of the government and the collapse of the state.

Criminal law is another area where there is considerable variation both in the West and in Asia. ${ }^{99}$ There is considerable variation with respect to the approval requirements for warrants and arrest, search and seizure rules, what constitutes arbitrary detention and interrogation issues such as access to a lawyer, the conducting of line-ups, the right to silence, and other issues such as the admissibility of tainted evidence. Indeed, half of the ECHR's caseload

97. See David Klinger \& Lt. Col. Dave Grossman, Who Should Deal with Foreign Terrorists on U.S. Soil?: Socio-legal Consequences of September 11 and the Ongoing Threat of Terrorist Attacks in America, 25 HARV. J.L. \& PUB. POL'Y 815, 824 (2002) (arguing for the deployment of the United States military in domestic law enforcement actions and that "Foreign individuals or groups (and U.S. citizens aiding and abetting them) who commit acts of war on U.S. soil should not be viewed as people who need to be apprehended under the aegis of the Fourth Amendment of the Constitution, which properly requires substantial restraint on law enforcement officials seizing citizens. .."; rather, such people should be treated as enemy soldiers under laws of war, whereby the military should have the right to make "informed decisions" that the people they are dealing with are foreign terrorists (or U.S. aiders) and attack using reasonable force, including tanks and missiles to blow planes out of the sky). See also Poe et al., supra note 51, at 296 (finding that civil war has a positive and statistically significant impact on political repression).

98. The Siracusa Principles on the Limitation and Derogation Provisions in the International Covenant on Civil and Political Rights, 7 HUM. RTs. Q. 3, 1 (1985). Principle 39 of the Siracusa Principles interprets "threat to the life of the nation" to mean that a danger (i) is present or imminent; (ii) is exceptional; (iii) concerns the entire population, and (iv) constitutes a threat to the organized life of the community. Id.

99. See, e.g., ERIKA FAIRCHILD \& HARRY DAMMER, COMPARATIVE CRIMINAL JUSTICE SYSTEMS (2d ed. 2000). 
consists of fair trial and length-of-proceeding issues. ${ }^{100}$ While systematic empirical studies are lacking, it appears that most Asian nations seem to give police broader powers to arrest and detain than do the United States and Western Europe countries.

Systematic empirical studies would also help clarify the range of diversity with respect to other rights issues, such as free speech, freedom of association, and freedom of the press. ${ }^{101}$ For instance, Thailand, one of the more tolerant countries in Asia in terms of freedom of speech and the press, prohibits the advocacy of communism, criticism of the government, and incitement of ethnic, racial, or religious tensions. Yet without an examination of actual cases and the specific context, it is not clear where the lines are drawn exactly, how onerous such restrictions are, what the penalties are, whether the laws are applied fairly or used to attack opposition party figures, and so on. Empirical studies would also shed light on sexuality/gender issues (same-sex marriage, homosexuality, pornography, prostitution, transexuality), obscenity laws, the public-private distinction and privacy issues (urine tests, mandatory treatment for drug addicts, identity cards, the right of employers to read employees' emails), the value of life (abortion, female infanticide, euthanasia, the right to die, eugenics, sale of body parts), paternalism and the limits of autonomy and consent (Can experienced business persons consent to unconscionable contract provisions? Can a woman consent to be beaten by her husband? Can dwarfs consent to dwarf-tossing contests where the participants compete in bars to see who can throw the dwarf the farthest? Can people consent to sadomasochistic acts that amount to criminal offenses in the case of non-consenting parties? ${ }^{102}$ Can criminal defendants consent to trial without counsel?), family law issues (domestic violence, spousal rape, children's duty to support their parents, parents' duty to take care of children, the right to divorce, child custody, the division of property upon divorce, inheritance laws, surrogate motherhood), labor issues (the right to form a union and to strike, minimum wage, child labor), economic rights (the right to housing and medical care), cultural rights (the rights to the use of language, culturally important lands and waterways, freedom of religion), and collective

100. Yourow, supra note 50, at 67. For a discussion of administrative detention and criminal law in China in light of international standards and practices elsewhere, see Randall Peerenboom, Out of the Pan and into the Fire: Well-Intentioned but Misguided Recommendations to Eliminate All Forms of Administrative Detention in China, NORTHWESTERN L. REV. (forthcoming 2004).

101. See CHRISTIE \& ROY, supra note 8. Christie and Roy provide brief summaries of these issues. Id. See also Scott Goodroad, The Challenge of Free Speech: Asian Values $v$. Unfettered Speech, An Analysis of Singapore and Malaysia in the New Global Order, 9 IND. INT'L \& COMP. L. REV. 259 (1998). Welsh, supra note 74, at 894 (noting that while eighty-six percent of Malaysian respondents supported free press, only forty percent thought the press should be free to discuss sensitive issues, while only fifty-two percent thought it should be free to criticize the government, with many of those favoring constructive criticism).

102. See Laskey v. United Kingdom, 29 Eur. Ct. H.R., (ser. A), at 120 (1997) (holding that British laws prohibiting adult, sexual sado-masochistic acts do not violate right to privacy). 
rights (the right to self-determination and the right to a clean environment as reflected in environmental laws).

\section{The Margin of Appreciation and the Benefits and Limits of Diversity}

The margin of appreciation suggests that a certain amount of variation in how the aforementioned issues are handled is to be expected, and arguably justifiable, or at least acceptable, given the alternatives. Assuming persuasion does not work, the alternatives presumably would be to force others to accept ideas that they do not believe in by using increasingly coercive measures ranging from public censure to economic sanctions to military intervention. Some moral realists might believe there is a right answer to each of these questions, and some universalists (who may or may not be moral realists) might hold out hopes for a detailed overlapping consensus on all of these issues. But moral realism, as I shall argue below, does not get us very far in practice. Nor does an overlapping consensus seem likely, or even desirable. Diversity is a good thing. There is no reason for all countries to adopt the same conceptions of the good life or to resolve all issues in the same way. Diversity makes experimentation possible. ${ }^{103}$ It also allows people with different interests and conceptions of the good life a greater chance of finding a suitable place to live. ${ }^{104}$

At the same time, there are limits to the benefits of diversity. At some point - a different point for different people that will vary depending on the issue-most people will protest against acts that violate their own sense of what is right and, if reasoned arguments or emotional appeals fail to persuade, they may in some cases be willing to escalate the degree of coercion required to bring the actions, if not the beliefs, of others into line with their own moral beliefs about what is right. Of course, a number of practical factors will-and should-enter into the calculus. There is little point advocating sanctions if they will not achieve the desired end, especially if they will lead to more human rights violations and greater suffering on the part of those whom the sanctions are supposed to benefit. ${ }^{105}$ More controversially, states will also consider geopolitical factors and their own national interests when deciding what course of action to take. Humanitarian intervention is rare and occurs only when there is a consistent pattern of massive human rights violations. ${ }^{106}$

103. In fact, many ECHR cases rely on such experimentation to support their positions. For example, in Lustig-Prean and Becket v. U.K, 29 E.H.R.R. 548 (2000), the court relied on information about gays in the military in other countries to strike down a United Kingdom law. The court argued that the experiences of other countries showed that such a restriction was not necessary for security purposes. $\quad C$ f. Dronenburg v. Zech, 741 F.2d 1388 (D.C. Cir. 1984) (upholding ban on gays in U.S. military).

104. Obviously many people will not have the means (economic or psychological) to move to another country more to their liking, but at least some people will be able to take advantage of the opportunity.

105. See infra text accompanying notes 141 .

106. See supra text accompanying note 143 . 
Even then, in many cases of widespread abuse of human rights, the Security Council fails to intervene.

As the proper response will and should depend on the nature and scope of rights violations, the first round of the debates could have profited from a more consistent recognition of the differences among Asian countries with respect to rights and an attempt to separate out the truly evil regimes from others that protected various rights to various degrees. Myanmar and North Korea are at one extreme, with citizens enjoying few if any rights and also suffering from a low level of economic development. Other countries, such as China, offer little protection when it comes to many civil and political rights, but do better with respect to other rights-or at least they are not significantly worse than other countries with respect to economic, social, and cultural rights. Singapore, Thailand, and the Philippines are generally protective of rights, though there are pockets of problems, often in the area of civil and political rights. Thailand and the Philippines are also dealing with poverty and a range of related socioeconomic problems. Japan, Hong Kong, South Korea, and Taiwan have relatively good records across the board (again, relative to other countries around the world). Of course, there are rights violations and areas of concern even in these countries. Japan, for instance, has problems with discrimination against women, Koreans, and other socially disadvantaged groups. ${ }^{107}$ Western (or Asian) liberals still might object to where the line is drawn on some issues, such as free speech in Hong Kong or the rights of criminal defendants in Japan, preferring greater protection of the individual even if at the expense of group interests. However, Western liberals disagree with libertarians, communitarians, conservatives, and others in their own countries on these issues. In the West, however, liberals are in the majority and hence, by and large, able to get their own preferences enacted into law and upheld by the courts. ${ }^{108}$

The first round of debates also frequently suffered from the failure to distinguish between democracy and liberal rights. The lack of democracy does not necessarily mean the failure to protect rights. Hong Kong has

107. See CHRISTIE \& ROY, supra note 8 , at 275 .

108. Rights are often justified, particularly but not exclusively by liberals, by noting the need to protect individuals and the minority against the tyranny of the majority. Rights are an anti-majoritarian device to the extent that they remove certain issues from the legislative arena (and the majoritarian decision-making process) and trump the interests of the group and society as a whole. Even if rights in all societies serve an anti-majoritarian function, however, how they are conceived, justified, and interpreted will vary. Thus, while communitarians and liberals, for example, all believe, at least in certain circumstances, that the rights of the individual override the democratic majoritarian decision-making process, they will differ as to how often and for what reasons the rights of the individual should trump the will of the majority. Liberals tend to side with the individual more often, casting a broader and more impenetrable web of protective rights around the individual, than their fellow conservative or communitarian rightsbased democrats. If they have majority control of the legislature and liberal judges dominate the courts, liberals will be able in most cases to have their views imposed on those who do not agree with them. 
adequately protected rights, though not always interpreted as liberals do, even though it is not a democracy (and was not a democracy under the British). ${ }^{109}$ Conversely, a state may become democratic (or at least hold elections) and yet not necessarily become liberal or adequately protect human rights. Indeed, it is easy to overstate the value of democracy for the protection of human rights, at least in the short term.

Despite the much-vaunted third wave of democratization in the 1980s and 1990s, regimes that combined meaningful democratic elections with authoritarian features outnumbered liberal democracies in developing countries during the $1990 \mathrm{~s} .{ }^{110}$ These regimes have been described in a variety of ways: semi-democracies, electoral democracies, illiberal democracies, soft or semiauthoritarian states, semi-dictatorships or a form of electoral authoritarianism. A number of quantitative studies have found that the third wave has not led to a decrease in political repression, with some studies showing that political terror and violations of personal integrity rights actually increased in the 1980s. ${ }^{111}$ Other studies have found that there are non-linear effects to democratization: transitional or illiberal democracies increase repressive action. Fein described this phenomenon as "more murder in the middle"- as political space opens, the ruling regime is subject to greater threats to its power and so resorts to violence. ${ }^{112}$

More recent studies have also concluded that the level of democracy matters: below a certain level democratic regimes oppress as much as nondemocratic regimes. ${ }^{113}$ Using the Polity IV Index consisting of five components-competitiveness of executive recruitment, competitiveness of participation, executive constraints, openness of executive recruitment and regulation of participation —one study found that political participation and limits

109. See U.S. State Department Human Rights Report 2000 Hong Kong, U.S. Dep't of State, available at http://www.state.gov/g/drl/rls/hrrpt/2000/eap/686.htm (released Feb. 23, 2001) (last visited Sept. 18, 2003).

110. Steven Levitsky and Lucan Way, supra note 23.

111. James A. McCann and Mark Gibney, An Overview of Political Terror in the Developing World, 1980-1991, in POLICY STUdies AND DeVELOPING COUNTRIES, VOL. 4, 15 , 23-24 (Stuart Nagel and David Louis Cingranelli, eds. 1996) (noting that political terror increased in the developing world in the 1980s and finding that democracy does not by itself ensure low levels of terror); see also Reilly, supra note 26 (finding no evidence that personal integrity rights are improving, and that over the period from 1976-1996, the number of countries with the best score actually decreased, countries with the worst score increased, while the mean remained about the same).

112. Helen Fein, More Murder in the Middle: Life-Integrity Violations and Democracy in the World, 1987, 17 HUM. RTS Q. 170 (1995).

113. Bruce Bueno de Mesquita et al, Thinking Inside the Box: A Closer Look at Democracy and Human Rights (2003), available at proceedings@ apsanet.org. See also Christian Davenport and David Armstrong, Democracy and Human Rights: A Statistical Analysis of the Third Wave (2002), available at http://apsaproceedings.cup.org/index.htm. But see S.C. Zanger, A Global Analysis of the Effect of Regime Changes on Life Integrity Violations, 1977-1993, J. OFPEACE 33 (2000) (finding that democracy leads to improvement in human rights performance within the first year of holding elections). 
on executive authority are more significant than other aspects, but that there is no human rights benefit at all until the very highest levels of political participation and executive constraints are achieved. However, these levels require moderate progress on each of the other subdimensions. In short, "there is no significant increase in human rights with an incremental increase in the level of democracy until we reach the point where executive constraints are greatest and where multiple parties compete regularly in elections and there has been at least one peaceful exchange of power between the parties... Put more starkly, human rights progress only reliably appears toward the end of the democratization process." 114

The results in Asia are largely consistent with the findings of these multiple country studies. In Indonesia, there have been numerous human rights violations after the fall of Suharto, most notably with respect to ethnic violence, the tragedy in East Timor, and the violence that marred the 1999 elections. Similarly, Amnesty International reported in 1993 that the human rights situation had not substantially improved under the democratic regime in South Korea. ${ }^{115}$ Even today, Kim Dae Jung has been unwilling or unable to do away with the strict National Security Law despite his campaign promises. Although Cambodia held elections in 1993 and 1998, the period was marked by battles between government armed forces and the Khmer Rouge, resulting in continued human rights violations including murder, rape, hostage-taking, and secret detention. ${ }^{116}$ The government offered an amnesty to key leaders and supporters of the Khmer Rouge, much to the dismay of many rights advocates. ${ }^{117}$ Nevertheless, stability remained an issue with a preemptive coup by Hun Sen in 1997 in which more than fifty people were killed, many of them shot in the back of the head after arrest. ${ }^{118}$ In the Philippines, democracy

\section{De Mesquite el at., supra note 113.}

115. AMNESTY INTERNATIONAL, REPORT (1993).

116. One can, of course, challenge whether Cambodia or Singapore or Malaysia are democracies in the relevant sense. A genuine democracy requires at minimum open, competitive elections, under universal franchise, of those in posts where actual policy decisions are made (the electoral dimension). It also requires sufficient freedom of association, assembly, speech, and press to ensure that candidates are able to make their views known and compete effectively in the elections, so that citizens are able to participate with reasonable effectiveness in the electoral process (the participatory process dimension). In addition, it requires the legal institutions to ensure that these freedoms are in fact realized and the election is carried out fairly (the rule of law dimension). Democracy therefore implies rule of law, but not vice versa.

117. David Chandler, Will There Be a Trial for the Khmer Rouge?, 14 ETHICS \& INT'LAFF. 67 (2000). Thus far, no one from the Khmer Rouge has stood trial for war crimes. Id. Cambodia continues to say that it will have such trials, but after a February 2002 fallout between Cambodia and the United Nations, it remains unclear whether the United Nations will be involved. Id. Even without the United Nations, however, there may be an international presence via individual foreign governments (India, etc.) if a tribunal ever does take place in Pnomh Peng. Id. See also Cambodia, U.N. in Khmer Rouge Talks, CNN World, June 3, 2002, at http://europe.cnn.com (last visited Nov. 14, 2003) (search for Cambodia, U.N. in Khmer Rouge Talks, CNN World, June 3, 2002).

118. Id. at 79. 
has not resolved pressing socioeconomic problems. At the end of the 1980s, seventy-five percent of the population lived below the poverty line. Under Ramos, the percentage was reduced by seven percent, but the gap between rich and poor grew. ${ }^{119}$ There have also been numerous rights violations, including disappearances, extrajudicial killings, arbitrary arrests, and prolonged detention, as the government continues to struggle against insurgents. ${ }^{120}$ Consistent with popular views in other countries threatened by terrorism and insurgents, most Filipino citizens apparently do not consider the government's tough treatment of terrorists as human rights violations. Preoccupied fighting terrorists, the government has been too weak to deal with corruption and violence, and democracy has been driven by cronyism, family networks in the countryside, and personalities, as in the ill-fated election of the actor Joseph Estrada. Thailand, for its part, has continued to struggle with prostitution and child labor, among other pressing socioeconomic issues. Poverty levels jumped from eight percent in 1996 to twenty percent in 1998 as a result of the financial crisis, eliminating much of the progress made in last twenty years. Some 800,000 school children and college students were forced to drop out of school; social problems such as alcoholism, depression and suicide increased; immigrants were no longer welcome; and trafficking in children and prostitution increased. ${ }^{121}$

The experiences of these countries suggest that there is something to the arguments of those who claim that stability and economic development are essential to the quality of life, that subsistence is the most important right, and that the biggest issue is poverty - and if developed Western countries really were concerned about human rights and the quality of life of Asian citizens, they would do more to help developing countries eliminate poverty rather than simply preach about violations of civil and political rights. ${ }^{122}$ These arguments, framed in terms of the indivisibility of rights, the existence of a hierarchy of rights, the need to trade-off first generation civil and political liberties to ensure economic growth, and the need for strong authoritarian governments to ensure stability, constituted a second nexus of rights issues in the first round of debates.

\section{Conflicts among rights: hierarchies and trade-offs}

That the Bangkok and Vienna Declarations stressed the indivisibility of rights was hailed by rights advocates as a major success in the battle against Asian values. In my view, it was anything but that. Rather, it is a good example of what the Chinese call sleeping in the same bed but having different

119. CHRISTIE \& ROY, supra note 8 , at 187.

120. Id. at 188, 191-92.

121. Id. at 166.

122. See also supra note 58 (multi-country empirical studies showing that the level of economic development is a statistically significant factor in respect to protection of human rights). 
dreams (tongchuang yimeng) and of how an apparent consensus turns out to be chimerical once one probes beneath the surface. Opponents of Asian values wanted this language to counter the arguments of some Asian governments and advocates of Asian values that subsistence was the most fundamental right and that the need to ensure economic growth required a temporary trade-off of civil and political rights. Some Asian governments and Asianvalues advocates, on the other hand, wanted it to obviate what they perceived to be the excessive emphasis of the Western-dominated international human rights community on civil and political rights. They wanted to ensure that they are given credit for improving the material standards of living in their countries (even if few Asian governments really want social, economic, and cultural rights to be taken so seriously as to actually obligate them to spend the resources necessary to satisfy such positive rights). Furthermore, they wanted to emphasize that poverty is the most pressing issue and, therefore, developed states should take the collective right to development seriously and help developing states develop.

Accepting the indivisibility of rights does not address the issues of whether there is or should be a hierarchy of rights or whether Asian governments are justified in restricting civil and political rights in some circumstances in the name of stability and economic growth. There is no conceptual reason why all good things must go together. In fact, the dominant view for years was that collective and group rights were not really human rights at all, because human rights attached only to individuals. ${ }^{123}$ Fortunately this view is no longer so prevalent, and collective rights have become widely accepted. In any event, the notion that various types of rights are mutually supportive is compatible with a hierarchy among rights and the need to work out a ranking system to deal with conflicting rights. Given the proliferation in rights, conflicts among rights are inevitable. Does anyone seriously believe that all rights listed in human rights documents are equally important: that, for example, the right to holidays with pay is as important as the right to subsistence, or that the right to be brought before a judge promptly upon arrest is as important as the right not to be sold into slavery? ${ }^{124}$ No system treats all rights as equal. In the United States, courts distinguish between fundamental rights, which require a compelling state interest and least restrictive means analysis, second-tier rights requiring intermediate scrutiny, and garden-variety

123. See DONNELY, supra note 20, at 20.

124. Jeremy Waldron, Liberal Rights: Two Sides of the Coin, in LIBERAL RIGHTS, COLLETED PAPERS 1981-1991 (1993). Waldron argues that economic and social rights must be taken seriously, even offering a defense of periodic holidays with pay. However, he also notes that rights do conflict and that it is imperative in a world characterized by conflict and scarcity to face up to the need to make trade-offs and to balance various rights claims. Id. In response to Henry Shue's well-known attempt to prioritize rights, Donnelly argues that one could have all of the basic rights mentioned by Shue and still live a degraded, shabby life. See DONNELIY, supra note 20, at 41-42; HENRY SHUE, BASIC RIGHTS PAGE? (1980). This is true, but it does not obviate the need to rank and trade off rights in the real world. Id. 
rights that can be limited by showing only that the government has not acted irrationally or arbitrarily. International law distinguishes between jus cogens rights that do not require assent from member states and treaty rights that do require consent, with customary law forming an intermediate, rapidly expanding category where traditional indicia are increasingly less important. ${ }^{125}$ International human rights treaties also distinguish between rights that are derogable and non-derogable. ${ }^{126}$ Moreover, the rights documents themselves, in effect, discriminate against rights in that some are more binding than others. ${ }^{127}$ An analysis of ECHR cases shows that in practice there are some inviolable core rights, such as the right against torture; some preferred, fundamental, or specially protected rights, including certain due process and personal freedom rights; and then other rights that may be derogated and receive less protection. ${ }^{128}$

Simply put, every legal system, whether international or domestic, must deal with conflicts of rights every day. The rights of some citizens to education and housing or to the use of their cultural land may require limitations on

125. HENRY STEINER \& PHILIP Alston, INTERNATIONAL HuMAN RIGHTS IN CONTEXT 22436 (2000). Granted, jus cogens rights are controversial and in practice play little if any role in part because of the expansion of treaty and customary law. Id.

126. The Siracusa Principles on the Limitation and Derogation Provisions in the International Covenant on Civil and Political Rights, supra note 98, at 7-10.

127. International Covenant on Civil and Political Rights, G.A. Res. 2200A, U.N. GAOR, Supp. No. 16, at 52, U.N. Doc. A/6316 (1966), available at http://www1.umn.edu/humanrts/ instree/b3ccpr.htm (last visited Sept. 18, 2003) [hereinafter ICCPR]. Compare, for example, the vague nature of the obligations of the International Covenant on Social, Economic and Culture Rights with the operative clauses of the International Covenant on Civil and Political Rights. Id.

Article 2 of the ICCPR states:

1. Each State Party to the present Covenant undertakes to respect and to ensure to all individuals within its territory and subject to its jurisdiction the rights recognized in the present Covenant, without distinction of any kind, such as race, colour, sex, language, religion, political or other opinion, national or social origin, property, birth or other status.

2. Where not already provided for by existing legislative or other measures, each State Party to the present Covenant undertakes to take the necessary steps, in accordance with its constitutional processes and with the provisions of the present Covenant, to adopt such legislative or other measures as may be necessary to give effect to the rights recognized in the present Covenant.

Id. (emphasis added).

Compare International Covenenant on Economic, Social, and Cultural Rights, available at http://shr.aaas.org/thesaurus/icescr.html (last visited Sept. 18, 2003). Article 2 of the ICSECR states:

Each State Party to the present Covenant undertakes to take steps, individually and through international assistance and co-operation, especially economic and technical, to the maximum of its available resources, with a view to achieving progressively the full realization of the rights recognized in the present Covenant by all appropriate means, including particularly the adoption of legislative measures.

Id. (emphasis added).

128. Yourow, supra note 50, at 190. 
the property rights of other citizens either in the form of higher taxes or the requisition of their land for public interest purposes. ${ }^{129}$ The right of a group to maintain its culture may involve practices regarding marriage, divorce, and inheritance that are at odds with women's rights to equality and non-discrimination. The rights of Indian women to life and equality may require limitations on the practice of sati (widow burning) and thus, the practice of religion for (male) Hindus. The right to free speech may conflict with the rights of minorities not to be subject to discriminatory hate speech.

The real issues here are not whether there should be a hierarchy of rights, but (i) how to rank rights, or perhaps more accurately how to weigh rights against competing interests, including other rights claims, and (ii) whether civil and political rights really must be traded off to ensure stability and economic growth. The second issue often involves severe limitations on rights by authoritarian regimes, but it is not an issue that applies, at least anymore, to economically advanced Asian countries such as Japan, South Korea, and Taiwan. As it is related to the key economic issue of whether democracies or authoritarian regimes are more likely to achieve sustained economic growth, I will postpone discussion of it until later.

In contrast, the first issue is in some ways more fundamental and likely to endure in that it involves contentious line drawing exercises that pit liberals against communitarians, conservatives, and anyone else who does not privilege autonomy and the interests of the individual over other interests, including social order and the interests of the group. The excessive individualism of liberalism is a pressing concern in Korea, as it is in Taiwan, Japan, Hong Kong, and in Western countries as well. ${ }^{130}$ This issue has often been construed as a battle between Asian communitarians and Western liberals. Opponents of Asian values, in addition to noting that there are Western communitarians and Asian liberals, question whether Asian governments are really interested in promoting communities. ${ }^{131}$ They also deny that liberal democracies are antithetical to communities, and claim that in fact communities are more likely to flourish in liberal democracies than under authoritarian regimes. Communitarians counter that communities are not likely to flourish under either liberal or authoritarian regimes. What is needed is a non-liberal, communitarian form of democracy. Whatever the merits of these arguments, the issue is much broader than the debate between communitarians and liberals. It is a truly universal issue that everyone of whatever persuasion must face in that it involves drawing a balance between the individual and the group

129. See Ghai, supra note 7, at 1128 . Indicative of the importance of a country's history and particular circumstances, South Africa, given its history of apartheid that has resulted in an extreme imbalance in wealth, determines compensation in takings cases based on the history of the acquisition and use of the property as well as its current use and market value. Id.

130. See, for example, the essays on Asian values in the Korea Journal, volume 41 .

131. See, e.g., Xiaorong Li, "Asian Values" and the Universality of Human Rights, in DEALING WITH HUMANRIGHTS: ASIAN AND WESTERN VIEWS ON THE V ALUE OFHUMAN RIGHTS, supra note 7, at 37 . 
across a whole range of issues. It is certainly possible that the majority of Asians may prefer a different balance than the majority of Westerners, though again we need more detailed empirical studies to examine differences in practice across a wide range of specific issues. ${ }^{132}$ The balancing issue is likely to endure because simply noting a majority preference one way or the other will not end the debates - those in the minority can continue to claim that they are right based on any number of reasons and theories from pragmatic considerations to moral realist arguments about what is really right, whatever that means other than that those making the claim are particularly committed to their position.

Of course, many issues do not turn on general conflicts between the individual and the collective or claims by individuals against the state but rather involve competing claims among different groups. Hindu women seeking to avoid widow-burning have different interests than Hindu men arguing for the free practice of religion. Poor citizens arguing for higher taxes have different interests than the rich. Muslims arguing for exceptions to generally applicable laws have different interests than non-Muslims. Deciding these issues requires consideration of context-specific factors. This contextsensitivity greatly qualifies, if not undermines, claims of universality. In most cases, such issues cannot be resolved by appeal to the broad rights stated in international human rights documents or based on some universal metric or matrix.

One of the interesting aspects of the first round of debates was that the focus was on the universality of international human rights. Few took notice that many of the same issues arise regularly in the course of domestic systems, including culture-specific challenges to the universality of rights, ${ }^{133}$ the need to take into consideration historical, cultural, religious, and economic contingencies when interpreting and implementing rights; conflicts between rights and the need to balance certain rights against other rights and to create a hierarchy of rights; and disagreements over the extent to which prevailing moral values should be taken into consideration in determining the rights of individuals. ${ }^{134}$ In the second round, a number of works have noted that while the international human rights regime differs in some important respects from domestic legal systems, many of the issues arise in both contexts. ${ }^{135}$

132. See, e.g., Cerna., supra note 47.

133. See supra note 54.

134. See infra text accompanying notes 203-205.

135. See Donoho, supra note 55, at 441-42 (noting similarities and suggesting that the jurisprudence of the ECHR and the United States may provide important insights for international human rights decision-making bodies); Michael Dowdle, How a Liberal Jurist Defends the Bangkok Declaration, in NEGOTIATING CULTURE AND HUMAN RIGHTS, supra note 7, at 125 (arguing that the Bangkok declaration's claims are consistent with a conception of how rights are understood and implemented in practice in the West especially with respect to the need to interpret rights in light of the existing context, to balance competing rights claims, and to give due consideration to cultural concerns and local values). For an earlier argument that much of what the Chinese government claims about rights is actually consistent with prevailing concep- 


\section{Sovereignty issues and sanctions}

Many Asian government officials and citizens have complained vehemently that international human rights should not be an excuse for strong-arm politics and interference in the domestic affairs of a country. However, it is not only Asian governments that view international human rights as a threat to sovereignty. ${ }^{136}$ The United States has refused to sign a number of human rights treaties, including a treaty to protect the rights of migrant workers and the first protocol to the International Convention on Civil and Political Rights (ICCPR) that would give individuals the right to lodge complaints based on the ICCPR. It has signed but failed to ratify a number of other treaties including the Convention on the Elimination of All Forms of Discrimination Against Women and the International Covenant on Economic, Social and Cultural Rights. The United States has also precluded the human rights treaties it has ratified from having any significant domestic effect through a series of reservations. Meanwhile, the United States has opposed the establishment of the International Criminal Court (ICC), and threatened to cut off military aid to any country that ratifies the treaty to establish the ICC and to use force if necessary to prevent U.S. citizens from having to appear before the ICC. ${ }^{137}$

Other non-Asian states have also argueg that foreign countries and international human rights bodies are permitted to intervene in another country's affairs only when there is a consistent and systematic practice of gross violations. ${ }^{138}$ This position is not wholly without legal basis. Article 2 of the Charter of the United Nations declares that "[n]othing contained in the present Charter shall authorize the United Nations to intervene in matters which are essentially within the domestic jurisdiction of any state." 139

Nevertheless, broad sovereignty claims of the kind raised by China and some other Asian states are difficult to maintain nowadays, given the increasing reach of international law and the participation of all countries in the international legal order. China's claims, for instance, are undermined to a considerable extent by its membership in the United Nations, its accession to

tions and, once one moves beyond overstated rhetoric, especially practices of rights in Western countries, see Randall P. Peerenboom, What's Wrong with Chinese Rights? Toward a Theory of Rights with Chinese Characteristics, 6 HARV. HUM. RTS. J. 29 (1993).

136. A number of scholars have portrayed the rapid expansion of customary international human rights law as a threat to United States sovereignty. See, e.g., Jack Goldsmith, Should International Human Rights Law Trump US Domestic Law?, 1 CHI. J. INT'L L. 327 (2000). Of course, others disagree. See, e.g., Kenneth Roth, The Charade of U.S. Ratification of International Human Rights Treaties, 1 CHI. J. INT L. 347 (2000).

137. See US Vote to Use Force Against UN Court, S. ChINA Morning Post, May 12, 2002 , at 6.

138. See HENRY STEINER \& PHILIP ALSTON, supra note 125, at 588-90.

139. U.N. CHARTER art. 2, para. 7. 
various international human rights treaties, the increasing reach of general customary international law principles, and its own participation in the United Nation's imposition of sanctions on South Africa as well as its support of resolutions condemning human rights violations in Afghanistan and the Israeli Occupied Territories. It would be hypocritical for China to participate in the condemnation and sanctioning of other states for violating human rights and yet assert that the United Nations and other countries are interfering in China's domestic affairs when they condemn China or impose sanctions under similar circumstances.

On the other hand, allowing that China's sovereignty defenses fail in some circumstances does not mean that China's sovereignty concerns are never justified. Nor does it resolve all or even most of the more specific hotly contested issues such as what the response of the United Nations or individual states should be to ongoing rights violations in China or other countries.

There is a wide range of possible responses to human rights violations from persuasion to criticism and censure to the imposition of aid conditions or economic sanctions to military intervention. Some involve the United Nations or other international or regional rights bodies; others involve states either on a multilateral or bilateral basis; still others involve private parties from non-governmental organizations (NGOs) to academics to corporations or individuals. What is striking is the limited effectiveness of these measures. The United States and other Western countries tried to isolate Myanmar in the late 1980s and early 1990s, suspending aid and banning arms sales. In contrast, ASEAN states tried constructive engagement. Neither policy worked. ${ }^{140}$ The United States eventually dropped its hard-line policies in favor of a "critical dialogue" approach. This also failed to lead to any significant change. Nor have foreign governments been very successful in influencing China's behavior. As Susan Shirk, the former Deputy Assistant Secretary for East Asian and Pacific Affairs at the United States State Department, acknowledged, the United States has tried a variety of approaches in dealing with China from linking human rights to trade to delinkage combined with dialogue to public shaming through speeches and resolutions at the United Nations. However, as she rightly points out, "basically, nothing has

140. See CHRISTIE \& ROY, supra note 8 , at $98-99,102$. The failure of sanctions to improve the human rights situation in Asia is consistent with the general evidence of the limited effect of sanctions. See Gary Hufbauer et al., ECONOMIC SANCTIONS RECONSIDERED (2d ed. 1970). See also LISA MARTIN, COERCIVE COOPERATION: EXPLAINING MULTILATERALECONOMIC SANCTIONS (1992) (examining the conditions under which states cooperate rather than addressing directly the issue of whether sanctions work and finding that a key determinant of success is credibility and willingness of states seeking to impose sanctions to bear costs for doing sosomething often lacking in the human rights context where states are reluctant to forego business opportunities, compromise geopolitical interest or risk the lives of their own citizens in peacekeeping missions for the sake of improving human rights in the target country). 
worked." 141 On the contrary, external pressure has led to resentment, even among reformers in China. ${ }^{142}$

Countries rarely want to risk their own interests to protect the rights of citizens in other countries by imposing economic sanctions. The United Nations Security Council has been reluctant to impose sanctions for human rights violations and only does so in extreme situations such as South Africa, Kosovo, Rwanda or Iraq where there is a consistent pattern of massive human rights violations. ${ }^{143}$ Aid conditions and sanctions may be useful in sending a message that human rights violations will not be tolerated and, in some cases, have produced some meager positive results, such as in China's periodic release and exiling of high profile prisoners. However, they often backfire and do more harm than good. ${ }^{144}$ The debate about sanctions may be held hostage by domestic politicians or be opposed by the business community that fears lost opportunities. As a result, states may lack the fortitude to impose and maintain sanctions. This oscillation then sends the message that human rights issues may be traded off for short-term domestic economic and political benefits. The selective imposition of sanctions on a few countries, and not always the countries with the worst rights records, also gives rise to cries of a double standard and calls into question the fairness of the sanctions and the motives of the country imposing the sanctions. Moreover, whether such sanctions help or hurt the people within the target country is often unclear. Economic sanctions may worsen the living conditions for many people who are already living on the edge of subsistence. In recent years, sanctions have fallen out of favor among many in the human rights community. ${ }^{145}$ To the extent that sanctions remain an option, the call is for "smart" sanctions that would minimize the adverse consequences experienced by innocent citizens

141. Remarks of Susan Shirk at the Asia Pacific Executive Forum, ASIA COMMENT, Jan. 16-19, 2001.

142. See Students' Attitudes Toward Human Rights Surveyed, BBC SUMMARY OF WORLD BROADCASTS, May 4, 1999. In a survey of 547 students from thirteen universities in China, eighty-two percent claimed that for other countries to initiate anti-China motions before the U.N. Commission on Human Rights constituted interference in China's internal affairs; seventyone percent believed that the true aim of the United States and other countries in censuring China was to use the human rights issue to attack China and impose sanctions on it, with sixtynine percent maintaining that this constituted a form of power politics. Id.

143. For a list of Security Council sanctions, see http://www.un.org/News/ossg/sanction .htm (last modified July 2003) (last visited Sept. 18, 2003).

144. The 1993 Bangkok Declaration at the center of the Asian values controversy objects to "any attempt to use human rights as a conditionality for extending development assistance." See HUMAN RIGHTS AND INTERNATIONAL RELATIONS IN THE ASIA-PACIFIC REGION, supra note 7 , at 204.

145. See General Comment No. 8, Committee on Economic, Social and Cultural Rights, U.N. Doc. E/1998/22, Annex V (1977). 
in the target state. Nevertheless, many critics question the wisdom and feasibility of even smart sanctions. ${ }^{146}$

\section{The compatibility of human rights and indigenous traditions}

One of the dominant themes of the first round was whether Confucianism, Islam, Buddhism, Hinduism, and other Asian traditions are compatible with, or can be reconciled with, democracy and contemporary human rights. Some universalist advocates of human rights argue that if indigenous traditions are at odds with human rights, then they must give way. ${ }^{147}$ Their faith in the normative superiority of international human rights notwithstanding, any such claim raises many questions. How does one justify the superiority of contemporary rights over traditional values? Does it matter whether one is arguing from within the particular tradition or from outside of it? Is there some neutral or objective moral standard to which one may appeal? Does liberal tolerance require toleration of illiberal regimes?

While hardcore universalists would simply reject local traditions when in conflict, others have sought to reconcile rights with local traditions, a strategy that has been only partially successful. ${ }^{148}$ One approach has focused on interpretive strategies. Passages that are seemingly antithetical to rights are limited to their historical context. One seeks to show how passages must be reinterpreted, given different conditions today, to achieve the intended purpose of the text as a whole, which itself may be reinterpreted in terms of today's circumstances and more general principles found in the text. Another typical approach has been to search traditional texts and practices for analogues to modern rights or indigenous values similar to the values that underwrite contemporary human rights, and then to argue that there were, or at least could be, Confucian rights, Buddhist rights, and so on.

I have discussed these strategies elsewhere and will not repeat those remarks here. ${ }^{149}$ Rather, I will illustrate in Part II some of the methodological issues that arise in trying to render indigenous traditions compatible with the basic pillars of modernity, including human rights, by taking up the example of Confucianism. For now, it suffices to point out that rights-discourse need not crowd out other normative traditions and that rights need not play the same role in every society. One of the issues in the first round was the

146. See Joy Gordon, A Peaceful, Silent, Deadly Remedy: The Ethics of Economic Sanctions, 13 ETHICS \& INT'L AFF. 123 (1999). See also Gary C. Hufbauer \& Barbara Oegg, Targeted Sanctions: A Policy Alternative?, 32 L. \& POL. IN INT'L. BUS. 11 (2000) (noting that success rate of targeted sanctions is about twenty-five percent compared to a success rate of thirty-four percent for general economic sanctions).

147. Jack Donnelly, Human Rights and Asian Values: A Defense of 'Westerm' Universalism, in THE EAST ASIAN CHALLENGE FOR HUMAN RIGHTS, supra note 7, at 87.

148. For the limits of these kinds of approach, see Peerenboom, supra note 7.

149. Peerenboom, supra note 7; Randall P. Peerenboom, Confucian Harmony and Freedom of Thought, in CONFUCIANISM AND HUMAN RIGHTS, supra note 52, at 234. 
centrality of rights within a political culture as opposed to other means of ordering society, such as reliance on religion or virtue-based character building. Joseph Chan, for instance, argued that Confucianism calls into question the prominence of rights as a means of ordering society relative to other more virtue-oriented approaches. In his view, rights will provide a fallback position, being invoked where virtues fail to obtain or personal relationships break down. ${ }^{150}$ Farish Noor points out that Ghandi relied on Hindu principles of non-violence to affect social change. He also argues that Aung San Suu Kyi is not a liberal political activist in the Western sense. She has objected to the "unbridled freedom" and "selfish individualism" found in Western liberal democracies. While she believes in human rights and democracy, her views are grounded in the humanist principles of Buddhism and Burmese culture. ${ }^{151}$

She has been successful in seizing the moral high ground from the ruling regime and gaining support from her fellow citizens in part because she has appealed to such principles. ${ }^{152}$

A discourse of rights may also complement and exist side by side with discourses of needs, capabilities and duties. However, in some cases there will be conflicts, and the various discourses may serve different functions or similar functions with varying degrees of effectiveness. ${ }^{153}$ Thus, the compatibility issue cannot be avoided completely.

Economic Issues

\section{Regime type and economic growth}

The advantages and disadvantages of democracy were also much debated in the first round. That some Asian citizens would harbor doubts

150. Joseph Chan, A Confucian Perspective on Human Rights for Contemporary China, in THE EAST ASIAN CHALIENGE FOR HUMAN RIGHTS, supra note 7, at 212-37. For a similar argument, see Peerenboom, supra note 135, at 29-58.

151. See BARR, supra note 6 at 19. Similarly, former Taiwanese President Lee Teng-hui and South Korean President Kim, both strong opponents of Asian values discourse, have objected to the excessive individualism and moral breakdown in Western countries. Kim has emphasized ethical education and spiritual values to stem the tide toward degeneracy associated with contemporary liberalism, while Lee has advocated Confucianism. Id. at 19-20.

152. Farish Noor, Beyond Eurocentricism: The Need for a Multicultural Understanding of Human Rights, in DEALING WITH HUMAN RIGHTS: ASIAN AND WESTERN VIEWS ON THE VALUE OF HUMAN RIGHTS, supra note 7, at 55 . Noor notes that lower class Malaysians were among the first to embrace Islam as part of a struggle for power. He claims that importing liberal democracy failed in Eastern Europe and will fail in many Asian countries. Accordingly, he argues that Asians must look to their own traditions and cultural resources to solve contemporary problems.

153. See Peerenboom, supra note 7. While rights and virtue-based systems are complementary on the whole, they may come into conflict in particular circumstances. For a clear discussion of the similarities and differences of rights discourse and needs discourse, see Jeremy Waldron, Rights and Needs: The Myth of Disjunction, in LEGAL RIGHTS: HISTORICAL AND PHILOSOPHICAL PERSPECTIVES 87 (Austin Sarat \& Thomas R. Kearns eds., 1997). 
about the most recent wave of democratization is understandable given the disappointing results of earlier experiments with democracy in Asia and the lackluster performance of many recently democratized states that has led to a reversion to authoritarianism in several. Indonesia tried democracy just after independence from the Dutch between 1950 and 1957. The experiment ended when Sukarno declared martial law. Thailand has gone through numerous cycles of democratic elections followed by military-led coups-since 1932, there have been some seventeen coups attempts. ${ }^{154}$ South Korea held elections in the 1960s and early 1970s before returning to authoritarian rule, at which point economic growth took off. The less-than-successful experiments with democracy in the Philippines from 1935 led to the declaration of martial law by Marcos in 1972. As discussed previously, even more recent experiments with democracy in the 1990s have not necessarily meant better protection of many rights or the end of socioeconomic problems. Of course, there have also been some success stories, most notably Japan since World War II. In South Korea and Taiwan, two of the other reputed success stories, many citizens remain surprisingly ambivalent about democracy. ${ }^{155}$

Although opponents of Asian values argue that democracy is an intrinsic good, ${ }^{156}$ much of the debate in Asia has turned on empirical issues rather than the inherent value of democracy. Interestingly, the rather poor empirical record of Asian democracy in the past was not central to the first round of debates. ${ }^{157}$ Rather, the key issue was whether a democratic or authoritarian regime was more likely to achieve economic growth and ensure stability. A number of theories were advanced to support both sides of the argument. ${ }^{158}$ There have also been numerous empirical studies. It is now common to claim that the results of such studies have been inconclusive. ${ }^{159}$ Nevertheless, although the studies did not show a definite winner with respect to regime

154. See CHRISTIE \& RoY, supra note 8, at 161. Christie observes that despite the coup attempts there has been relative stability, particularly between 1978 and the present. He describes the system as a semi-democratic, power-sharing scheme between the military and bureaucratic elite.

155. See Yun-han Chu, Larry Diamond \& Doh Chull Shin, Halting Progress in Korea and Taiwan, 12 J. DEMOCRACY 122 (2001) (finding that "support for democracy lags well behind the levels detected in other emerging and established democracies. And on some dimensions of belief, the two publics exhibit a residual preference for authoritarian or nondemocratic principles, akin to the portrait of traditional or 'Asian values."').

156. Amartya Sen, Human Rights and Economic Achievements, in THE EAST ASIAN CHALLENGE FOR HUMAN RIGHTS, supra note 8, at 88-99.

157. But see Kausikan, supra note 7, at 230 (observing that claims that democracy and civil and political rights are basic to survival do not correspond with the historical experiences of Asian states).

158. For a discussion, see PEERENBOOM, supra note 74, ch. 10.

159. See, e.g., SEN, supra note 7, at 11 . This claim is frequently supported by reference to Adam Przeworski \& Fernando Limongi, Political Regimes and Economic Growth, $7 \mathrm{~J}$. ECON. PERSP. 51 (1993) (noting that of twenty-one studies, eight found in favor of democracy, eight in favor of authoritarianism; and the rest were inconclusive). However, Przeworskin and Limongi do proceed to draw conclusions with respect to more particular issues. Id. 
type in general, the studies do allow conclusions to be drawn with respect to a number of other more specific questions (subject to the usual limitations of such studies).

It is now clear, for example, that when it comes to economic development, regime type is not as important as the stability of the regime and variations within regimes. ${ }^{160}$ In particular, regimes that are market-oriented, dominated by technocrats, and relatively free from corruption are more likely to be successful. Second, and a corollary of the first, although some authoritarian regimes have been successful at promoting economic growth, not all have. Conversely, although some democracies have been successful at promoting economic growth, not all have. Third, all else being equal, authoritarian regimes tend to outperform democratic regimes at relatively low levels of economic development. ${ }^{161}$ Thus, promoting democracy in very poor countries may be putting the cart before the horse. Fourth, some Asian countries, including China, may not yet have reached the level of development that makes it likely that there will be a transition to democracy, and even if there were, that democracy would be sustainable. ${ }^{162}$ Fifth, when the conditions for a durable or stable democracy are not present, the transition to democracy often impedes economic development, at least in the short term. Sixth, economic development is not sufficient for political reform and the emergence of democracy. Countries may develop economically and not become liberal democracies, at least for a considerable period. Hong Kong and Singapore are good examples. ${ }^{163}$ Seventh, higher levels of prosperity and economic development are likely to lead to a growing demand for democracy-Taiwan, South Korea, Thailand and Indonesia are good examples. Whether or not economic development is the cause of democratization, in the long term, economically advanced countries are likely to be and to remain democracies. However, while democracy proponents often claim that authoritarian regimes are particularly vulnerable to economic downturns, ${ }^{164}$ so are democracies, at least at relatively low levels of growth. ${ }^{165}$

160. See Przeworski \& Limongi, supra note 159, at 51.

161. Robert Barro, Democracy: A Recipe for Growth?, in CURRENT ISSUES IN ECONOMIC DEVELOPMENT: AN ASIAN PERSPECTIVE 67-106 (M.G. Quibria \& J. Malcolm Dowling eds., 1996).

162. See PEERENBOOM, supra note 74. Some countries may be able to sustain democracy at lower levels of development than others. However, China is not a likely candidate given the many obstacles to democracy. Id.

163. See also Welsh, supra note 74 (finding in Malaysian survey little support for the thesis that economic development and the rise of a middle class will lead to calls for democracy). As in China, many of the wealthy and middle class oppose democracy, either because they fear it will lead to disorder or because it could lead to reforms that would undermine the relationships on which their economic success has depended. Id. See PEERENBOOM, supra note 74.

164. CHRISTIE \& ROY, supra note 8, at 130.

165. Adam Prezowski \& Fernando Limongi, Modernization: Theories and Facts, 49 WORLD POL. 155 (1997). 


\section{Trade-off arguments}

Central to the first round of debates were two trade-off arguments. The liberty trade-off refers to the argument that civil and political freedoms must take a back seat to economic development. The equity trade-off is the argument that economic growth will not benefit all equally, and may, in the shortterm, actually increase inequality and make some of the least well-off even worse-off; nevertheless, growth should still be pursued because the immediate task is to make the pie bigger, with redistribution of the pieces to come later.

Arguments on both sides of these issues tended to collapse into claims about whether authoritarian or democratic regimes are more likely to lead to growth or to be over-generalized in other ways. It was either all or nothing: either economic growth and stability justified any and all restrictions on civil and political liberties, or it justified none. However, in most cases, carrying on the discussion at this level is not sufficient. Many people believe, for instance, that democracy is not appropriate for China at this stage and that given the potential for instability, the government is justified in limiting certain civil and political rights in the name of social order (and, because social chaos would undermine economic growth, in the name of development). Yet, they also believe that the government unduly restricts civil and political rights. We need to move beyond these general arguments and consider specific instances of restrictions. As Bauer and Bell helpfully point out, Asian governments typically "present narrower justifications for curbing particular rights in particular contexts for particular economic or political purposes;" thus, "trade-off arguments for rights violations cannot be refuted solely by appealing to general principles." 166 Critics of repressive government policies must examine each case in detail to determine whether the social crisis is real and the government is employing the least restrictive or at least a proportional means to overcome it. ${ }^{167}$ As we have seen, such issues are complex and have led to controversial judgments in Europe; the same can be expected in Asia.

166. The EAST ASIAN CHALLENGE for HUMAN Rights, supra note 7, at 8.

167. Universal Declaration of Human Rights, G.A. Res. 217A, U.N. GAOR, 3d Sess., U.N. Doc. A1810 (1948). The standards under international law, particularly in the jurisprudence of the ECHR, are whether the restriction is (i) prescribed by law; (ii) for a legitimate purpose, specifically to protect public safety, order, health or morals, or the fundamental rights and freedoms of others; and (iii) necessary or at least proportional for the purposes prescribed. Id. Article 29 of the Universal Declaration of Human Rights contains a common restriction clause:

In the exercise of his rights and freedoms, everyone shall be subject only to such limitations as are determined by law solely for the purpose of securing due recognition and respect for the rights and freedoms of others and of meeting the just requirements of morality, public order and the general welfare in a democratic society. 
As for the equity trade-off, critics of Asian values note that high growth in authoritarian regimes frequently goes hand in hand with sharp disparities between rich and poor. Christie cites as examples Indonesia, Vietnam, Myanmar, and Thailand. ${ }^{168}$ On the other hand, some non-democratic regimes have done better in spreading the wealth, including Hong Kong, Singapore, and China, although the gap is growing at alarming rates in China. ${ }^{169}$ Moreover, democracy does not necessarily mean an egalitarian distribution. One need only consider the Philippines, India, or for that matter, the United States to appreciate that unfortunate fact. ${ }^{170}$ In any event, while it is true that economic growth is consistent with poverty, lower income, and more economic hardship for some people and an increasing gap between the rich and poor, it is also true that for poverty reduction to be sustainable, economic growth is necessary. Hence, the equity trade-off may in some cases be an issue of the timeframe. As Bauer and Bell again insightfully observe, "Social and economic rights seem particularly vulnerable as societies move toward integration in a global marketplace, whereas this same transformation may contribute to greater protection for civil and political rights in the long run."171

\section{Confucianism and economic development}

A third economic issue in the first round was the role of Confucianism in economic growth in Asia, especially in East Asia. Views ranged from it was/is very important to it wasn't/isn't important at all. ${ }^{172}$ It is striking that Confucianism, once blamed for retarding capitalism and economic growth in Asia, could suddenly become a main cause of such growth. Given that Confucianism didn't change, it would seem that other factors were at play. If anything, modernity and capitalism may have changed the culture and

168. Christie \& RoY, supra note 8 , at 16.

169. See Carl Riskin et al., Introduction to The Retreat from Equality, in CHINA'S RETREAT FROM EQUALITY 3 (2001) (the Gini coefficient of inequality in household income rose by seven percentage points, to eighteen percent, between 1988 and 1995; "Seldom has the world witnessed so sharp and fast a rise in inequality as has occurred in China.").

170. See John Gledhill, Liberalism, Socio-Economic Rights and the Politics of Identity: From Moral Economy to Indigenous Rights, in HUMAN RIGHTS, CULTURE AND CONTEXT 70, 7273 (Richard Wilson ed., 1997). GNP reached a historic high in the United States in 1990, having grown over $25 \%$ in a decade. At the same time, child poverty increased by $21 \%$ so that one in five American children lived in poverty. Id. The United States "ranked" fourteenth in the world in terms of life expectancy and twentieth in terms of infant mortality. Almost $30 \%$ of the poor had no medical insurance in 1991. Id. Somewhere between five and ten million Americans experienced homelessness in the late 1980s. While the United States is not ranked very highly in these economic indicators, it is second only to Russia in incarceration rates. THE SENTENCING PROJECT \& HUMAN RIGHTS WATCH, LOSING THE VOTE: THE IMPACT OF FELONY DISENFRANCHISEMENT LAW IN THE UNITED STATES 12 (1998).

171. THE EAST ASIAN CHALLENGE FOR HUMAN RIGHTS, supra note 7, at 19.

172. Compare EZRA VOGEL, JAPAN AS NUMBER ONE(1979) (arguing that Confucian values were critical to the success of the four Mini-Dragons), with Phillip Wonhyuk Lim, East Asian Economic Development, 41 KoREA J. Summer 2001. 
Confucianism. Jun Sang-in has observed that Koreans began to value punctuality and diligence in the 1960s when the nation was incorporated into the capitalist world economy. Accordingly, he claims Korea did not achieve capitalist development because Koreans were, from the start, diligent and hard-working, but rather capitalist development made Koreans hard-working and diligent. ${ }^{173}$ More generally, the basic problem is that it is difficult to control for "Confucianism," operationalize its role, and separate out the effects of different variables on economic growth.

\section{ROUND 2}

Despite several nuanced and insightful works, the first round on the whole was heavily politicized, with government leaders and spokespersons often driving the debates and setting the tone. Ad hominem arguments were common, with participants accusing others of bad faith and attacking their motives rather than examining the substance of their arguments. Anyone who defended Asian values was accused of being an apologist for dictators. Conversely, within Asia, those who were critical of Asian values ran the risk of being dismissed as a "self-demeaning 'Westophile,' a blind follower of neo-liberalism, or an idealistic citizen of the world." 174

Noting the irony in the fact that liberals were threatened and upset by a more pluralist approach to rights, as advocated by some in Asia, Singapore official Bilhari Kausikan suggested that the vitriolic attack on Asian values in the West has been overblown, disproportionate, and reflective of the West's parochialism and fears arising from a crisis of confidence in the economy and social order. ${ }^{175}$ Conversely, others accused Asian governments of an equally hysterical reaction to the rapid changes taking place in Asia. In this view, traditional Asian values are being eroded as Asian countries modernize. As a 1991 Singapore government report observed, "[t]raditional Asian ideas of morality, duty and society, which have sustained and guided us in the past, are giving way to a more Westernised, individualistic and self-centered outlook on life." 176 Critics then portray the discourse of Asian values as a

173. Jun Sang-in, Commentary on "Social Capital in Korea," 41 KorEA J., Autumn 2001, at 235. Phillip Wonhyuk Lim notes that many of the values and attributes that were supposed to have contributed to growth are hardly unique to Confucianism: an emphasis on education, hard-work, meritrocratic opportunities for advancement, respect for authority, and so on. Discussion: Asian Values, supra note 62 , at 282, 284. Of course, that they are not unique to Confucianism does not mean they are still not Confucian. Some traditions will have some or all of these values, others may not. Confucianism may be one of them. Confucianism may also assign a higher priority to them than other systems.

174. Lee Seung-Hwan, "Asian Values" and Confucian Discourse, 41 KOREA J., Autumn 2001 , at 210.

175. Kausikan, supra note 7, at 263.

176. CHRISTIE \& ROY, supra note 8, at 20 (quoting Leonard R. Sussman, "The Essential Role of Human Right," in THE WORLD AND I 41 (1993)). 
desperate, conservative, and hopelessly nostalgic attempt to delay the inevitable and impede progress.

There were enough bad arguments on both sides to provide professors of first year logic courses with a lifetime of examples. As we have seen, many arguments were over-generalized. The debates were often overly abstract and theoretical and lacked an empirical basis or a comparative framework. ${ }^{177}$ There were numerous sweeping claims, many of them insufficiently articulated to be falsifiable. Proponents of Asian values argued that because the West has its own problems, it should not criticize others. There is perhaps something to this argument. A priest who gambles, drinks, and visits prostitutes is less credible when he preaches to the flock about the need to avoid such evils. Perhaps countries do lose some of their moral standing when they criticize others because of their own rights problems. On the other hand, two wrongs do not make a right. The proper response should be for both sides to improve. ${ }^{178}$

Opponents of Asian values had their fair share of weak arguments. Many tried to portray the concerns about universalism as an anything-goes relativism, which clearly was not the case. ${ }^{179}$ Asian leaders such as Lee Kuan Yew have very definite ideas about what is right for Singapore. Lee even believes that the United States and others may be able to learn something from Singapore. But he doesn't see Singapore as a perfect state or a model for everyone, and he is willing to accept that others may prefer to solve complex social problems in different ways. ${ }^{180}$

Other opponents of Asian values mistakenly equated the mandate of heaven or Mencian notions of righteous government and the need to take

177. See Lee Seung-Hwan, supra note 174, at 249 (calling for an end to abstract discussions of Confucian capitalism and Asian values and arguing that discussions need to be based on concrete, tangible research). A number of the commentators in the Korea Journal debates made similar points. Id. See also Discussion: Asian Values, supra note 62, at 253 (Hahm Chaibong calling for a realistic experiential approach-lest Asian values become nothing more than a superficial, meaningless, rallying cry). Kang Jung-in observes that social and political scientists have emphasized the discourse of Asian values as a whole, but attempts to outline or concretely support their views are seriously lacking: "[w]hile opposing the holistic character of the Western-centric discourse, Asian values, which have not been fully elaborated and differentiated yet, tended to be idealized as a whole." Id. at 246-47.

178. Roger Cohen, America the Roughneck, N.Y. TIMES, May 7, 2001, at A10. Tired of American preaching, China supported the ousting of the United States from the Human Rights Commission in 2001, claiming that it was time the United States enter into a dialogue with other countries on an equal footing and stop using human rights issues as a tool to pursue its power politics and hegemony. Id.

179. Islam and Buddhism are, themselves, universalist in their claims. Thus, in some cases, the criticism of human rights as hegemonic, imperialistic constructs is not so much that they claim to be universal; rather, the claim is simply that they are not universal either as a matter of fact or as norms.

180. See Lee Kuan Yew, Culture is Destiny, in DeALING With HuMAN RightS: AsIAN AND WESTERN VIEWS ON THE VALUE OF HUMAN RIGHTS, supra note 7, at 75, 79. 
people as the basis (minben) with democracy. ${ }^{181}$ But the right to rebel does not give citizens the right to choose their leaders. Nor did Mencius advocate choosing government officials by elections or public participation in the government. Similarly, critics often claimed that there was too much diversity within Asia to speak of Asian values, but then they turned around and called for "Asian democracy" or referred to Asia as a whole when making comparisons to "the West." 182 In arguing for the universality of liberal values, many seemed to take it for granted that the views of liberal NGOs reflected the majority view in Asian countries, notwithstanding polling evidence that clearly shows liberals are a tiny minority in many Asian countries. ${ }^{183}$ Thus, the response of some opponents of Asian values to the Bangkok Declaration's attack on the universality of human rights was to point to the statement of Asian NGOs strongly endorsing, albeit more by proclamation than sustained reasoned argument, the universalism of human rights. Liberal opponents also tried to take the wind out of the sails of communitarians by demonstrating that in fact Asian governments often did not promote communities, and that when government officials invoked duties to the community, they really meant duties to the state. ${ }^{184}$ However, many communitarian supporters of Asian values also take issue with governments that conflate the interests of the community with the interests of the state and object to the lack of support for communities.

\section{Round 2: Less politicized arguments and more nuanced views about culture}

In contrast to the first round, the second round has been much less politicized and the arguments more sophisticated and balanced. Most participants in the debate are now more sensitive to the need to avoid reifying, essentializing, and nationalizing culture (how could they not be, given how often this rather obvious point has been made?). They are aware that there is a diversity of cultures within any country, and that cultures can and do change.

181. See, e.g., Kim Dae-Jung, Is Culture Destiny?, in Dealing WITH Human Rights: ASIAN AND WESTERN VIEWS ON THE VALUE OF HUMAN RIGHTS, supra note 7, at 98.

182. Id. at 102.

183. See Dinah PoKempner, Asia's Activists and the Future of Human Rights, 66 FORDHAM L. REV. 677, 679-80 (citing favorably the Asian NGO response to the Bangkok declaration). To cite just one of countless examples, Dinah PoKempner, the Deputy General Counsel of Human Rights Watch, makes the rather incredible assertion that the "most powerful rebuttal" of the arguments of advocates of Asian values, who espouse an Asian conception of rights, "comes from thousands of Asians themselves, who reject the idea that their culture requires a diminished set of individual freedoms." Id. But what of the millions of Asians who are willing to trade off civil and political rights for economic growth or who do think liberal rights excessively privilege the interests of individuals over the community? For polling evidence from China, see PEERENBOOM, supra note 74. See also SUSAN OGDEN, INKLINGS OF DEMOCRACY (2002).

184. See Xiaorong Li, supra note 131 , at 42. 
They are also wary about over-emphasizing culture as a causal factor. For instance, cultural values may play some role in the prevalence of torture. The emphasis on confession in Confucianism may lead to the excessive use of force. The dominance of utilitarian and consequentialist rather than deontological theories may also tip the balance away from protection of the rights of individual criminal defendants in favor of the interests of society. ${ }^{185}$ However, cultural factors are only part of the story, and perhaps not the most important part. As in the case of Nepal, the stability of a regime and the existence of terrorists and others bent on overthrowing the government increase the likelihood of torture. In China, the lack of modern forensic tools and the technology to tap phones, track down criminals, or conduct DNA tests also increases the importance of confessions and hence, the likelihood of torture. The rise of crime, which often accompanies modernization, may lead to hostility toward criminals. Worried about the rapid increase in crime, particularly violent crime, that has accompanied economic reforms, most Chinese citizens support the government's campaign to "strike hard" at crime. ${ }^{186}$ Few seem to care much about the fate of criminal suspects. Notwithstanding objections from international human rights agencies to China's unprecedented use of capital punishment, the overwhelming majority of Chinese citizens strongly support the death penalty. ${ }^{187}$ In a 1995 survey of 5006 citizens, less than one percent believed that the death penalty should be abolished, while more than twenty-two percent believed that there were too few death sentences. ${ }^{188}$

The rise of rational choice theories and institutional explanations of behavior have, in some cases, pushed cultural factors to the margins if not completely out of the picture. Nonetheless, it would be a mistake in the opposite direction to totally discount cultural factors and values. At the end of the day, values do matter, though how much, when, which ones, and why all require detailed context-specific studies. ${ }^{189}$ Unfortunately, there are still

185. Randall P. Peerenboom, Rights, Interests, and the Interest in Rights in China, 31 STAN. J. INT'L L. 359-86 (1995).

186. See Peerenboom, supra note 100.

187. Amnesty International, The Death Penalty in China: Breaking Records, Breaking Rules (Aug. 1, 1997), at http://www.web.amnesty.org/ai.nsf/Index/ASA170381997 (last visited Nov. 14, 2003). Amnesty International reported more than 6,100 death sentences and 4,367 confirmed executions in 1996 alone and noted that these numbers are based on public reports and are likely to fall far short of the actual numbers. Id.

188. Hu Yunteng, Application of Death Penalty in Chinese Judicial Practice, in IMPLEMENTATION OF LAW IN THE PEOPLE'S REPUBLIC OF CHINA 247, 255 (Jianfu Chen et al. eds., 2002). Granted, many citizens probably do not have a good sense of how many death sentences there are. Id. However, even if they had, whether it would matter is doubtful. Id.

189. Culture is invoked in a variety of ways. One way is where rights are rejected across the board as antithetical to a particular culture. Nowadays, few if any states reject rights in such a comprehensive way. But see Yash Ghai, Universalism and Relativism: Human Rights as a Framework for Negotiating Interethnic Claims, 21 CARDOZOL. REV. 1095 (2000) (suggesting that in Fiji, indigenous Fijians portrayed rights as antithetical to underlying values of indigenous social and political organizations). Much more common is to invoke culture to reject, limit or 
examples of excessively politicized polemics, as in the continued biased reporting of rights issues in some countries, ongoing strong-armed rights politics, and the premature celebration of many opponents of Asian values over the alleged demise of Asian values.

One striking characteristic of the first round was that there was not much of an attempt to link up the discussion of Asian values to the Western literature on multiculturalism, identity politics, and critical theory. There was little reference to the critical legal studies, law and society, or law and cultural studies literatures. One of the reasons for this is that politicians played a large role in the first round, not legal scholars, particularly Western legal scholars of a critical persuasion. The politicians may simply have had different backgrounds and interests. Moreover, the leadership even in some of the more authoritarian states in Asia is hostile to the quasi-Marxist, leftist politics of many critical theorists and law and society scholars. The agenda within these schools is generally the critique of modernity, including capitalism and the rule of law. This postmodern agenda, useful in the context of late modernity capitalism in the West, is at odds with the efforts of Asian governments to modernize, and thus, is likely to find little support among Asian-values advocates, be they academics or government officials. Similarly, critical scholars often oppose globalization in favor of local solutions. While this position would seem to be consistent with arguments against universalism and in favor of Asian values, some Asian governments see globalization as part of their efforts to modernize and useful in bolstering their legitimacy. Contemporary culture studies, including studies of culture and law, often take as their target the notion of a unified culture and nation-state, exposing the ways culture reifies power relationships and masks ideology. This agenda is at odds with that of those Asian governments seeking to invoke Asian values to strengthen the state. As leaders of multi-ethnic states, in many cases, they are also likely to be deeply concerned about the divisive effects of identity politics.

To be sure, multiculturalism, identity politics, and critical theories were not wholly absent from the first round, and they seem increasingly prevalent

localize particular rights. Culture is often directly relevant to a number of rights issues, as evidenced in the debates about multiculturalism, ethnic identities, the adoption of multiple official languages, bi- or multilingual educational programs, and the legality of cultural defenses and exemptions for particular groups from generally applicable laws. It is also more indirectly related to a number of other issues such as choice of institutions and outcomes with respect to many social issues. As we have seen, some societies may for cultural reasons assign a higher order to stability and social order and therefore limit the rights of criminal defendants more than other societies. In his laudable analysis of the relationship between culture and rights in designing constitutions in India, Canada, Fiji, and South Africa, Ghai tends to focus primarily on direct invocations of culture rather than the more indirect way culture matters in constructing, interpreting, and implementing a legal system. As a result, he tends to downplay the importance of culture in favor of explanations that highlight the balance of power and competitions for resources. Id. at 1099. 
in the second round. ${ }^{190}$ As elsewhere, their appearance frequently signals a politicizing of the discussion, suggesting that the trend toward less politicization may not last. ${ }^{191}$ Consider the debates over Orientalism and reverse Orientalism. It is true that some of the arguments on both sides have had an Orientalist cast to them. It is also true that Orientalism can come in different forms, some of which at first may seem diametrically opposed. In some cases, Orientalism takes the form of denying out-of-hand that Asian countries could implement "Western" institutions such as capitalism, democracy, rule of law, or human rights: we in Western countries have it, and they in Asian countries do not have it and never will. ${ }^{192}$ Alternatively, it may take the form of an imposition of a particular conception of capitalism, democracy, rule of law, or human rights on Asian countries. Despite the difference in form, the root problem is the same: the initial assumption of an excessively narrow conception of the institutions of modernity, one defined in terms of the contingent values and institutional arrangements of contemporary Western liberal democracies.

Notwithstanding the merits of exposing Orientalisms in some cases, debates about Orientalism are often too polemical. Lee, for example, dismisses explanations by Westerners of the recent economic crisis that emphasize favoritism, cronyism, familism, and authoritarianism as metaphysical rhetoric to justify "their" economic domination over Asia. However, it is not only Westerners who have raised such arguments. ${ }^{193}$ Further, it is not clear who is seeking economic domination, although Lee does mention Western scholars. It is doubtful, however, that Western scholars see themselves as a direct participant in or beneficiary from the economic development of Asia. Nor do I believe that many Western scholars would deny that corruption

190. See Shih Chih-yu, Human Rights as Identities: Difference and Discrimination in Taiwan's China Policy, in DEBATING HUMAN RIGHTS, supra note 8, at 144-63 (an insightful study of the interplay between human rights and identity politics in Taiwan).

191. Thomas Hylland Eriksen, Multiculturalism, Individualism and Human Rights: Romanticism, the Enlightenment and Lessons from Mauritius, in HUMAN RIGHTS, CULTURE AND CONTEXT, supra note 170, at 49-69. Eriksen sees great dangers in appeals to multiculturalism: "If . . . institutionalised differences form the core of multiculturalist practices, it is liable to regress into nihilism, apartheid and/or the enforced ascription of cultural identities." Id. at 53. Multiculturalism may (i) contribute to freezing ethnic distinctions and thereby heighten the risk of ethnic conflict; (ii) make members of minorities more vulnerable and less able to choose their own path; (iii) strengthen internal power discrepancies within minorities; (iv) direct public attention away from more pressing economic issues; and (v) contribute to a general moral and political disqualification of minorities in society-since they are not accorded the same rights and duties as everyone else, there is no reason why they should be respected as equals either. Accordingly, Eriksen would limit multiculturalism to where it is compatible with individual rights. Id.

192. Lee Seung-Hwan, supra note 174, at 238. In reverse Orientalism, Asians themselves argue that Asian values are so different that Asian countries could not possibly implement such institutions. As Lee Seung-Hwan points out, the use of stylized Oriental characteristics and Asian values to oppose Western imperialism can slip into ultra-nationalism. Id.

193. Id. at 204. 
existed and still exists in Western countries or claim that the negative values present in some contemporary Asian societies are permanent cultural traits, immutable to change.

\section{Beyond the universalism versus relativism debate}

Another feature of the second round has been the attempt to move beyond debates about universalism versus relativism, ${ }^{194}$ even though such philosophical debates continue to rage elsewhere. ${ }^{195}$ Numerous first round articles addressed issues related to the topic of universalism or relativism although without relying on the technical philosophical terminology of moral realism, metaethical relativism and the like. For instance, some commentators distinguished between the origins of rights, the importance of local circumstances for the implementation of rights, and moral arguments about whether rights were universal. ${ }^{196}$ Opponents of Asian values are surely correct that the fact that the modern conception of human rights originated in the West does not by itself necessarily render them any less attractive as normative principles for people from non-Western states, any more than the fact that airplanes or aspirin were invented in the West makes them less useful or desirable for those living in Asia. However, origins are important for psychological, political, and practical reasons. Given the history of exploitation by colonial Western countries, some Asian leaders and citizens may feel the need to resist the appearance of capitulating to the ideology of their former repressors.

194. See id. at 210; Manisha Desai, From Vienna to Beijing: Women's Human Rights Activisim and Human Rights Community, in DEBATING HuMAN RIGHTS, supra note 8, at 18496; Ghai, supra note 189, at 1096 (noting that the universal versus relativism has already proved sterile and unproductive and may be damaging); Donoho, supra note 54 (arguing that the political rhetoric surrounding the tired debate over cultural relativism has obscured the deeper issues that global diversity presents for the international human rights system and suggesting that more attention be paid to just how much diversity, pluralism, self-governance, and autonomy will be allowed); Richard Wilson, Introduction to HUMAN RIGHTS, CULTURE AND CONTEXT, supra note 170, at 3. See also HUMAN RIGHTS, CULTURE AND CONTEXT, supra note 170; Engle, supra note 8, at 323 (claiming "the debate over the Bangkok Declaration seems almost outdated. The argument for context has prevailed.") Lynda Bell, Andrew Nathan, and Ilan Peleg note in their introduction to a conference volume on Asian values that the participants were uncomfortable with the rigid dichotomy embedded in the first round of the debates between an arrogant universalism that seemed to force its values on others and a morally vacuous relativism that seemed to flee from hard judgments and to justify non-democratic practices. Lynda Bell, Introduction to NEGOTIATING CULTURE AND HUMAN RIGHTS, supra note 7, at 3-19.

195. See Jeremy Waldron, How to Argue for a Universal Claim, 30 CoLUM. HUM. RTS. L. REV. 305 (1999). As noted above, in the Western philosophical literature, the debate is often couched in terms of moral realism and objectivity. See, e.g., POSNER, supra note 36; Ronald Dworkin, Objectivity and Truth: You'd Better Believe It, 25 PHIL. \& PUB. AFF. 87 (1996); Brian Leiter, Objectivity, Morality and Adjudication, in OBJECTIVITY ANDMORALS 66-98 (responding to Dworkin).

196. See Xiaorong Li, supra note 131. 
Moreover, local circumstances, including cultural beliefs, philosophical and religious traditions, the level of economic development, and the nature and level of development of political and legal institutions are clearly relevant with respect to the implementation of human rights. ${ }^{197}$ Rights advocates have learned that implementation is easier and more effective when supported by local traditions, as confirmed by the experience of women's rights groups in Malaysia and Indonesia that have made considerable progress in their daily battles by working within their religious and cultural traditions. ${ }^{198}$

In general, laws that are not in accord with the values of a particular society will be difficult to enforce. ${ }^{199}$ Thus, if only for purely strategic or instrumental reasons, culture, traditions, and values do matter. ${ }^{200}$

Apart from strategic considerations, the implementation of rights is relative to local conditions in the legal sense that a country's obligations are in some cases tied to the level of economic development. The International Covenant on Economic, Social, and Cultural Rights requires states to use all appropriate means (which are not defined) to the maximum of available resources (which will depend on how each country prioritizes its needs and apportions spending on national defense and the military as opposed to social services and other normal government expenses) with a view to progressively achieving its obligations (over some undefined time period). ${ }^{201}$ More generally, all rights may be restricted in some circumstances. Thus, all rights will depend on local conditions. ${ }^{202}$ International human rights bodies, regional courts such as the ECHR, and domestic courts have a number of doctrinal and interpretive tools at their disposal to accommodate diversity in local circumstances. Such tools include vague phrases in limitation clauses such as "necessary in a democratic society" and the doctrines of proportionality, appropriateness, reasonableness, and legitimate government aim that are used in interpreting such clauses.

Universalists, of course, allow that the implementation of rights depends on circumstances, but would claim that the same set of circumstances should

\section{See Cross, supra note 58.}

198. See Peerenboom, supra note 7.

199. For yet one more example, see Susan Dicklitch, Failed Democratic Transition in Cameroon: A Human Rights Explanation, 24 HUM. RTS. Q. 152, 153 (2002) (noting that once stable, relatively economically developed countries such as Cote d'Ivoire, Zimbabwe, and Cameroon quickly degenerated into authoritarian and human-rights-abusive regimes due to the lack of a rights-respective society and culture; also arguing that when the mechanisms of democracy are grafted onto a political and social system that does not respect rights, competition breeds chaos and violence, not democratic progress).

200. See HENRY STEINER \& PHILIP ALSTON, supra note 125. It is interesting to note that different U.N. rights bodies have adopted different approaches. Id. The Human Rights Committee in charge of overseeing the ICCPR tends to be more legalistic and confrontational than the Committee in charge of overseeing CEDAW. Id.

201. G.A. Res. 2200, U.N. GAOR, 21st Sess., Supp. No. 16, at Art. 2, U.N. Doc. A/6316 (1966).

202. See supra note 167 , for examples of limitation clauses. 
lead to the same result, regardless of whether the state seeking to limit the rights is in the West or Asia. Differences in normative views from place to place are not considered a relevant circumstance. Thus, some universalists (especially moral realist universalists) object to the margin of appreciation doctrine, whether applied within Europe or more broadly. In this view, why should it matter whether three countries, five countries, all but one country or even all countries in Europe (or the rest of the world) prohibit same-sex marriage or allow capital punishment? What is morally right does not depend on the views of the majority.

However, allowing that circumstances matter when it comes to implementation of rights greatly reduces the distance between universalists and advocates of Asian values. After all, that is what the Asian-values advocates have been claiming all along. The disagreement then is narrowed to which circumstances are relevant. The more circumstances deemed relevant, the more the decision becomes context-specific and limited to a particular place and time, thus undermining universalism at least in implementation.

A second issue is why local values and norms should not be considered relevant. Even assuming local values should not be considered relevant to the question what is morally right, most people would allow that what is morally right is not necessarily the same thing as what is legally right. Even Ronald Dworkin, who continues to believe in a single right answer to legal questions, allows that the single right legal answer will not always be the morally right answer. ${ }^{203}$ Dworkinian judges, in making the law the best that it can be, must balance what is morally right with what fits with precedent and the constitution. For Jurgen Habermas, law also resides between facts and norms. Law is a combination of morals (which are universal), ethics (which are grounded in particular communities), and non-generalizable interests that reflect the particular interests of individuals and groups. ${ }^{204}$ Thus, at least some legal decisions will turn on local values (though Habermas is none too clear on where or how the lines between morals, ethics and interests get drawn and his examples are unpersuasive). For positivists such as H.L.A. Hart, law and morality are clearly distinguishable in theory. ${ }^{205}$ However, they will overlap in practice, because many laws will reflect local values. When the judges reach decisions based on such law, they will be reflecting local values. In hard cases, when the law runs out, judges may decide cases based on various factors, one of which may be local values. Similarly, Legal Realists such as Cardozo and Holmes also allow judges to consider local norms and values

203. RONALD M. DWORKIN, LAW'S EMPIRE (1986); Dworkin, supra note 195.

204. JÜRGEN HABERMAS, BETWEEN FACTS AND NORMS: CONTRIBUTIONS TO A DISCOURSE THEORY OF LAW AND DEMOCRACY (1996).

205. H.L.A. HART, THE CONCEPT OF LAW (1961). 
when reaching decisions, although they may differ over how much importance to attach to communal values. ${ }^{206}$

The debate over moral relativism does not get one very far when it comes to practical legal issues of how rights are to be interpreted and implemented. Rights, after all, are not just moral concepts. They are also legal instruments. Given the weak enforcement mechanisms of international human rights regimes, parties seeking to invoke human rights must often rely on domestic legal systems. However, domestic judges will need to interpret such rights in light of their constitution, domestic laws and other legal practices, including judicial practices. Local values will be reflected in the constitution, domestic laws and case precedents and will influence judges in deciding cases.

Philosophical discussions have been most successful in showing the limits of realism and antirealism, universalism, and relativism. ${ }^{207}$ They have also succeeded in clarifying variants that, in the process of qualification, become harder to distinguish in terms of practical consequences, despite the differences in labels and rhetorical packaging. ${ }^{208}$ Weak moral realism of the kind advanced by Thomas Nagel "need not (and . . . should not) have any metaphysical content whatever. It need only hold that there are answers to moral questions and that they are not reducible to anything else."209 As Posner notes, however, this kind of weak moral realism converges with his pragmatic, non-dogmatic moral skepticism. In practice, there is little difference because there are no convincing answers to contested moral questions unless they are reducible to ones of fact or errors of logic. ${ }^{210}$

For what it is worth, I am agnostic on the issue of moral realism. There are interesting and plausible arguments that can be made in its defense, but there are roughly equally interesting and plausible arguments that can be made against it. The same is true for various forms of normative and metaethical relativism and conventionalism. The basic point, however, and the reason I prefer agnosticism on the issue of moral realism, is that these kinds of

206. Benjamin Cardozo, The Nature of the Judicial Process (1921); OLIver WENDELL HOLMES, THE COMMON LAW (1881).

207. See supra text accompanying notes 195-97.

208. See DONNELLY, supra note 20, at 110 . In the end, even Donnelly accepts a weak cultural relativism. Id.

209. POSNER, supra note 36, at 10.

210. Id. Leiter seems correct in claiming that Dworkin's arguments against external skepticism show not that external skepticism is unintelligible, but that it is irrelevant. Leiter, supra note 195, at 84 . He also objects to "non-naturalist" accounts of ethics (i.e. accounts that reject natural science as the standard for objectivity in ethics) on the grounds that it leads to a weak notion of objectivity that reduces, if not eliminates, the distance between cognitivists and noncognitivists. Id. See also Jeremy Waldron, The Irrelevance of Moral Objectivity, in LAW AND DISAGREEMENT 186 (1999). 
philosophical debates are not useful in solving issues that arise in practice. ${ }^{211}$ That is why such debates have not played an important role in the Asianvalues discussion so far and will not in the future. Even if moral facts exist, there is no way of proving them to others in contested legal cases. As we have seen, hopes for an overlapping consensus are chimerical because there is not enough common ground to reach consensus on most human rights issues. ${ }^{212}$ Any such "facts" are too few or too abstract to do us much good when deciding the many controversial issues that arise every day. As Jeremy Waldron puts it, moral facts do not constrain the decision-making of judges or anyone else in a way that is important: "facts do not reach out like little gods and grab the decision-maker, preventing him from deciding capriciously or dictating themselves to him in any unavoidable way." 113

An intellectually honest moral realist would still have to say "I think slavery is evil" or "I think the cutting off of a hand is cruel and unusual punishment." A non-realist would do the same. Neither moral relativism nor antirealism (or even skepticism or emotivism) precludes giving reasons for one's beliefs or to justify one's decisions. As a practical matter, decisions have to be made, and they can be made on the basis of arguments and reasons. The antirealist cannot claim some ontological foundation for her view; nor is she likely to pound the table and claim that her view is "really right" or "true." Yet, she need not allow that anything is as good as anything else. In some cases, she might be able to persuade someone who holds a contrary view to change his position. She might be able to do this by showing how his view rests on mistakes of fact. For example, he might think that the maximum length for detention without charge should be four days, because if a suspect is beaten the bruises will clear up within that period. If it were the case that bruises generally take ten days to heal, then he might be persuaded to change his mind. Similarly, she might show that his beliefs about a certain issue are inconsistent with other beliefs that he holds or simply not likely to achieve the desired result and thus faulty on instrumental, means-ends grounds. ${ }^{214}$

211. They may be useful for other purposes, including the enjoyment of philosophers who like to ponder and debate such issues. Giving up on realism may also have other practical consequences, such as encouraging people who hold moral views that are at odds with the majority's view to be less defensive about them, although that assumes they are defensive about them now or that there would not continue to be practical reasons that lead them to be defensive about their views.

212. Even if there was enough common ground to reach reasoned agreement, parties may not argue in good faith because of political factors and self-interest. But even if they do argue in good faith, limits on their reasoning power and time to sort out all of the related issues may prevent them from reaching agreement.

213. Waldron, supra note 210 , at 186 .

214. On the other hand, I think philosophers tend to overestimate the importance of consistency to most people. In my experience, people may come to appreciate that some of their views are inconsistent, and yet still hold on to them. In some cases, they may feel that ultimately there is some way of reconciling them, but they just have not figured it out yet. But in other cases, they simply accept the inconsistency. Rather than give up their views, they sacrifice consistency. 
Clearly, some people seem to have a greater faith in their moral barometers than others. I am continually struck by how confident people can be about the proper solution to contested moral issues, particularly given sophisticated and seemingly persuasive arguments on both sides. In most cases, it does seem that their views are more firmly held because they believe the logical force of reasons in support of their positions is compelling. More often it seems their views are simply based on unshakeable intuitions about what is right and wrong. Having made up their minds-or rather their hearts - they then seek out philosophical arguments to support their intuitions. If anything, one would think a high level of philosophical sophistication would undermine such confidence in an open-minded person given the strong arguments that can be mustered for the opposing view in most cases of contested moral issues. Similarly, one would think that exposure to other people with radically different but equally firmly entrenched intuitions and immersion in other cultures with different comprehensive worldviews would at least give one pause. Unfortunately, that does not seem to be the case. On the whole, it seems that moral realists and universalists tend to be people with firm intuitions that do not easily give way to doubts caused by philosophical arguments or encounters with others who hold opposing intuitions.

Nevertheless, even antirealists, moral relativists, pragmatists, and for that matter, most skeptics and emotivists will find some actions so offensive or abhorrent that they will protest. ${ }^{215}$ They will then have to decide what to do about it, particularly if persuasion fails to change the other side's beliefs or behavior. This is the pressing moral issue in practice, and one for which abstract discussions about universalism versus relativism and realism versus anti-realism provide no constructive guidance. It may be the case that moral realists and universalists are more likely to employ more coercive measures across a wider range of issues when persuasion fails than antirealists and moral relativists, but it need not be so. For most people the decision will turn on a variety of factors, including the particular issue, how strongly one feels about it, estimates about how much and what kind of coercion will be needed, the likelihood of success of the measures, and the possibility of adverse collateral consequences. Having reached a decision, the realist may dress up the conclusion in the language of objectivity and moral fact. However, if someone disagrees with the realist's decision, the realist packaging will add nothing to the weight of the arguments and reasons for the particular decision and in many cases will simply frustrate and alienate the other side. One of the advantages of focusing on actual disputes and cases rather than abstract theories is that universalists and relativists may find common ground. When

215. Justice Oliver Wendell Holmes used the term "the puke test" to describe the process when United States judges upheld a constitutional right and struck down legislation passed by democratically elected legislatures; in contrast, Justice Frankfurter preferred the more genteel "shocks the conscience" test. Others would set a lower standard. 
they do not, the differences in their views will be clearer, more focused, and anchored in real problems rather than "counter-examples" that are not really contested.

The attempt to move beyond universalism and relativism may coincide with a shift at a philosophical level from moral realism to a more pragmatic approach, either because of the growing number of advocates of philosophical pragmatism, particularly in the United States, or simply because of the limits of moral realism when it comes to what to do about contested moral issues in practice. Since it seems that few people read the philosophical literature and even fewer are likely to change their beliefs based on philosophical arguments alone, I would wager the latter is a more likely explanation. In any event, the growing consensus for the need to move beyond universalism versus relativism has highlighted the importance of law, politics, sociology, and anthropology.

Although human rights are part of an international legal framework, the first round of debates made little reference to international law, other than superficial appeals to the Universal Declaration of Human Rights and other treaties for broad statements of human rights principles. There were few concrete studies of international human rights jurisprudence or case law, of how international human rights bodies have sought to achieve their objectives in promoting human rights, of how Asian countries have worked with and in some cases resisted international human rights bodies, or of how the international human rights regime interacts with domestic legal regimes. Nor were there many comparative, empirical, or historical legal studies of rights issues. In contrast, recent articles and books have addressed such issues as the rights of indigenous peoples under international law, developments in the area of women rights at the 1993 Conference in Vienna and the 1995 World Conference on Women and their implications for international law, China's efforts to resist being censured in Geneva, and Japan's use of aid to promote democratization and human rights. ${ }^{216}$ Many of these studies emphasize the limits of international law to solve human rights issues and the important role of politics. ${ }^{217}$ In some cases, political scientists have appealed to the political science and international relations literature to shed light on governments' rights policies and actions in terms of more generally applicable theories of

216. Benedict Kingsbury, The Applicability of the International Legal Concept of "Indigenous Peoples" in Asia, in THE EAST ASIAN CHALLENGE FOR HUMAN RIGHTS, supra note 7, at 336-77; ANN KENT, CHINA, THE UNITED NATIONS AND HuMAN RigHTS (1999); Radhika Coomaraswamy, Reinventing International Law: Women's Rights as Human Rights in the International Community, in DEBATING HUMAN RIGHTS, supra note 12, at 184-96; Manisha Desai, supra note 194; Hoshino Eiichi, Human Rights and Development Aid: Japan After the ODA Charter, in DEBATING HUMAN RIGHTS, supra note 12, at 199-221.

217. See Kingsbury, supra note 216. See also Lucinda Joy Peach, Are Women Human? The Promise and Perils of "Women's Rights as Human Rights," in NEGOTIATING CULTURE AND HUMAN RIGHTS, supra note 7, at 153-96 (noting that Thai women are themselves not sympathetic to legalistic, rights-based approaches to their problems). 
realism, constructivism and liberalism (as the last term is used in international relations theory, i.e., to refer to the impact of domestic politics and constituencies on a state's international policies). ${ }^{218}$

The recognition that rights are imminent in and constitutive of social relations has led to a greater role for sociology and anthropology in recent debates. Early on, Geertz observed that law is a way of social imagining, a system of meanings. ${ }^{219}$ Law defines and creates social realities as well as reflects them. However, law is not only a form of thought and a system of signs; it is also a means of exercising power in that law sanctions and legitimates state violence. Human rights arose in part as a response to the modern state and the need to protect the individual given the development of highly individualist capitalist economies and the emergence of more powerful states, together with the breakdown of traditional social networks. Sociological studies remind us that human rights are not founded in the eternal moral categories of social philosophy, but are the result of concrete social struggles. By focusing on how rights-based discourses are produced, translated, and utilized in various contexts, they shed light on how international rights and cultures combine in particular contexts to create social meaning and channel competing forces seeking to advance their own interests and gain power. ${ }^{220}$

In this era of globalization, rights discourse is everywhere, or almost everywhere. However, the discourse of international rights interacts with national law, local law, and customs in different ways. As Sally Engle Merry observes, in mobilizing law in local contests for power, locals reinterpret and transform Western law. ${ }^{221}$ Sometimes global legal discourses infiltrate and influence local laws and norms, but sometimes they are resisted. In some cases, local practices and understandings may become incorporated into international law. Sociological studies allow us to better understand how human rights law shapes local normative orders, how and when domestic movements use or resist international law, and how domestic courts incorporate or curtail the reach of international law.

\section{Beyond Asian values?}

Writing in 1999, before many of the Asian countries had recovered from the financial crisis, Frances Fukuyama declared that the Asian values debate was over: "Since few people today seem to be interested in making the case

218. See Helfer, supra note 1 , for an interesting article in this vein though outside the Asian region.

219. ClIFFORD GEERTZ, Local Knowledge: Fact and Law in Comparative Perspective, in LOCAL KNOWLEDGE 167-234 (1983).

220. HuMAN RIGHTS, CULTURE AND CONTEXT, supra note 170.

221. Sally Engle Merry, Legal Pluralism and Transnational Culture: The Ka Ho'Okolokolonui Kanaka Maoli Tribunal, Hawai'i, 1993, in HUMAN RIGHTS, CULTURE AND CONTEXT, supra note 170 , at $28-48$. 
for Asian values as the basis for distinctive political or economic institutions, criticizing the concept may seem a bit like beating a dead horse." 222 As the active second round debates show, Fukuyama once again seems to have been a bit too quick to declare a winner in the historical sweepstakes. Key questions for consideration are whether "Asian values" is a useful analytical concept; whether we have exhausted this line of inquiry or whether there is more to be gained from pursuing it further; and if there is still something to be gained, what issues need to be examined and how.

Before rushing to get rid of "Asian values," it is helpful to consider the reasons it has been and continues to be invoked. Indeed, even if one thinks that the term is vacuous, misleading, analytically barren, and likely to cause confusion, it may not be possible to do away with it any more than one can do away with other contested terms such as "democracy" or "rule of law".

Invoked to counter the universalism of the human rights movement, "Asian values" was a natural outgrowth of the growing importance of the movement. As the international human rights regime grew in power and started to have some real bite, it was inevitable that it would give rise to a reaction by those bitten. Asian countries began to feel the bite in the late 1980 s and early 1990s, when they increasingly became subject to growing public censure. China in particular needed to defend itself after the crackdown in Tiananmen. Its 1991 Human Rights "White Paper" included many of the main points that would come to define the first round: the claim that although some rights are universal, their interpretation and implementation depends on local circumstances, including the level of economic development, cultural practices and fundamental values that are not the same in all countries; the argument that subsistence is the main right and the main problem is poverty, which Western developed countries should do more to address; the complaint of the Western bias of the international human rights movement and its excessive emphasis on civil and political rights and the individual at the expense of the community and collective; the criticism of the hypocrisy of Western imperialists who were guilty of human rights violations in Asia and continue to have their problems at home today; the defense of the importance of sovereignty and the need to avoid strong-arm rights politics; and the plea to discuss human rights based on a principle of mutual respect. ${ }^{223}$

222. Fukuyama, supra note 8 , at 151.

223. Human Rights in China, 34 BEIJING REV., Nov. 4-10, 1991 [hereinafter White Paper]. Lee Kuan Yew popularized the term "Asian Values" at an academic seminar in 1977. Although he has contrasted Asian values with Western values, he has at other times rejected the more expansive "Asian values" in favor of Confucian values, while allowing that even among Confucians there are many differences. The other great champion of Asian Values has been Mahathir. Lee and Mahathir share a preference for communitarianism, emphasize the family, value democracy but a nonliberal version of it, lament the corrupting influence of excessive individualism associated with liberalism and stress the (Confucian) values of hard work. Both also maintain that a strong state is necessary for economic development. Mahathir, however, has placed greater weight on the right to development and played up in the particular the neo- 
Lee Kuan Yew, for his part, emphasized the need for a strong government to ensure economic growth and social order. Moreover, whereas China did not couch its arguments in terms of Asian values, Lee expanded (perhaps overexpanded) his claims beyond Singapore to Asia more broadly. As the leader of a small city-state, Lee may have needed to cast his arguments as part of a broad-based movement to be taken seriously. Thus, his sometimes overstated arguments may have been a calculated strategy to drum up regional support against Western liberal democracy and the increasing role of largely Westerndominated international human rights and financial institutions.

Many of the arguments against the human rights movement need not be framed in terms of Asian values. As we have seen, the United States and other Western countries have also begun to worry about the movement's encroachment on their sovereignty. ${ }^{224}$ But as the dominant power, the United States is better able to resist encroachment. Indeed, international law scholars continue to debate whether the International Criminal Court can succeed without the support of the United States. ${ }^{25}$ In contrast, Asian countries may have needed to ban together to have any political clout within the Western-dominated international rights movement. In that sense, Asian values may have served and may continue to serve a useful purpose for some, depending on their political preferences.

Asian values may also be a response to globalization. Globalization appears to be increasing sensitivity to differences. The more similar we become, the more we focus on what makes us unique or special. ${ }^{226}$ As a result, ethnicity, gender, and religious identities take on more significance. Ethnic conflicts in Bosnia, the rise of Islamic fundamentalism, the Israeli conflict with the Palestinians may all be contributing to a global trend toward heightened awareness of identity politics and multiculturalism. Such concerns are likely to continue to fuel the search for non-Western identities, particularly given that many Asians are not all that happy with liberalism. Having modernized, many Asians are now discovering that a market economy, democracy, rule of law, and human rights do not solve all their problems.

colonialist theme of Western exploitation of the developing world. See BARR, supra note 6, at 39. While the PRC leadership did not expressly make Asian values the centerpiece of their post Tiananmen response to the international community, many of the themes announced in the White Paper draw on or fit nicely with some of the Asian values arguments of Lee and Mahathir. Moreover, it was China's political power that allowed advocates of Asian values to force the issue onto the international human rights agenda, leading ultimately to the Bangkok Declaration and Vienna Declaration in 1993.

224. See supra notes 137-146.

225. Jack Goldsmith, Should International Human Rights Trump U.S. Domestic Law?, 1 CHI. J. INT'L L. 327, 336-37 (2000).

226. In Mauritius, as Africans and Indians have become increasingly culturally similar in terms of language, a way of life and general outlook, they have increasingly emphasized differences in part because their cultures are threatened. They are also coming into closer contact and competing for scarce resources. Eriksen, supra note 191. See also Hahm Chaibong, Why Asian Values?, 41 KOREA J., Summer 2001, at 270. 
With modernity comes unequal incomes, apathy, alienation, prostitution, crime, and disenchantment. As Choi Won-shik comments, "The crisis of Western capitalism reveals that the Western Way has lost its role as the guiding light of the twenty-first century. The Asian values debate came about in the process of trying to find a new model to save the Western Way from impending collapse."227

While some opponents have portrayed Asian values as a defensive, conservative reaction to the modernization of Asia and the usual sort of problems that accompany modernity, Hahm Chaibong puts a more positive spin on it. Hahm notes that many Asians were never comfortable with Western values. They always saw their own civilization as superior. However, during the Cold War, one was either a communist or capitalist. There was no time to reflect on traditional civilization. Once the Cold War ended, Asians could reflect on other issues, including their differences with Western capitalist states. ${ }^{228}$ The economic rise of some Asian countries gave them the confidence to stand up for their own traditions and to argue that they succeeded by combining Western institutions and indigenous (East) Asian values. $^{229}$

Notwithstanding these explanations of why it is unlikely that the Asian values debate will go away, many think that it should. The argument against Asian values can be summed up in Daniel Bell's remark- "not Asia, not values."230 The first part calls into question the analytical utility of Asian values as a concept. As has often been noted, Asia is a big place, with tremendous diversity-too much, critics suggest, to speak about a singular set of Asian values. As many have also pointed out, there is sometimes a tendency to reduce Asian values to Confucianism, which is clearly a mistake given the importance of Islam, Buddhism, Daoism, and many other belief systems in Asia. $^{231}$

However, a pluralism of Asian values is still Asian values. ${ }^{232}$ There is nothing wrong with noting a diversity of values and still claiming that they are Asian. Furthermore, not every country within Asia needs to share every single feature. There may still be dominant patterns within Asia. Nor does it matter that "Asian values" is a construct, as Bell notes. ${ }^{233}$ Of course it is. So is "the

227. Discussion: Asian Values, supra note 62, at 288.

228. Id. at 267.

229. Chaibong, supra note 226 , at 270 . To be sure, the positive sense of pride may in some cases turn into a narrow-minded nationalism that can be manipulated by the state to deflect attention away from pressing social problems. China for instance has appealed to nationalist sentiments to shore up its legitimacy.

230. Daniel A. Bell, Beyond Asian Values, 41 KoreA J., Winter 2001, at 163.

231. See, e.g., Fukuyama, supra note 8.

232. See Welsh, supra note 74, at 896 (noting that seventy-six percent of the respondents in Kuala Lumpur and fifty-six percent of those in rural areas believed there were distinctive Asian values, though they differed over what they were).

233. See Bell, supra note 230, at 163. 
West," or "liberalism."234 Both encompass a tremendous diversity of views. Nevertheless, there are still dominant trends in Western thought. Liberalism clearly has a stronger hold than communitarianism in the West, for example, whereas the opposite seems to be true in Asia, although perhaps collectivism is a more apt description than communitarianism.

Bell notes that not all Asian countries face the same issues. That is true. Nevertheless, there are considerable family resemblances across a variety of issues. For instance, in addition to communitarianism or collectivism, one could point to a higher priority assigned to order, stability and economic growth relative to individual freedoms and autonomy; the importance of social networks; a different and greater role for the family than in modern Western liberal democracies; differences across a range of gender issues; differences with respect to the treatment of criminals; resentment toward the human rights policies of Western powers; and preference for a perfectionist or paternalistic state in which the state actively sets the moral agenda for society rather than the liberal neutrality which has been challenged with increasing frequency in the West as well. There are also a number of issues that affect many, though not all, countries in Asia. All but Thailand experienced periods of colonialism. As developing countries, a number of Asian countries also share the belief that developed countries should do more to eradicate poverty. In any event, even if the "only" issue was a difference with respect to individualism versus the collective, that might be a sufficiently major difference with such important consequences in so many areas whether economic, social, political or legal that it alone might be enough to justify the continued reference to Asian values.

Bell and others note that many of these issues are not unique to Asia. ${ }^{235}$ There are, for example, communitarians in the West as well. ${ }^{236}$ However, that does not make these issues any less Asian, especially when you consider a cluster of issues and the ranking of the various values within the overall value scheme. For instance, family and gender may be treated somewhat differently in Asia than elsewhere, even allowing for some variation within Asian countries and some overlap with other countries. Fukuyama argues that modernization has had a very different impact on family structure in Asia than it has in Europe and North America. Fukuyama also sees gender relations as an example of Asian exceptionalism, although he thinks over time there is likely to be convergence even with respect to the family and gender. ${ }^{237} \mathrm{He}$ is probably correct. Globalization has produced convergence in many areas

234. Id. Any comparative project must begin by constructing categories that highlight certain features and simplify to some extent. However, the first round suffered from overly simple constructs that lacked a firm empirical foundation.

235. Bell, supra note 230 , at 162 .

236. However, communitarians in the West on the whole may be more liberal than their Asian counterparts.

237. Fukuyama, supra note 8. 
including the family. ${ }^{238}$ However, convergence is a matter of degree. Generally, one can find evidence of both convergence and continued divergence with respect to forms of capitalism, democracy, rule of law, and human rights. The pace and path of change is also likely to reflect the different starting points.

In the final analysis, the question is whether Asian countries share enough common ground for the term to be useful. To some extent, that will depend on what one's project is. There may be more common ground in certain areas than in others. In general, I tend to agree with Bell that in most cases "Asian" is too broad a qualifier to capture the significant differences for most comparative purposes. However, at this stage, we need more detailed empirical studies across a range of issues in a number of Asian and Western countries before we can conclude that there is not enough in common among Asian countries and difference from Western countries to render the term Asian values useless, at least with respect to the "Asian" part. Opponents of Asian values sometimes seem to suggest or assume that if we can only do away with references to "Asian values" all of our problems will be solved. To that end, one common suggestion is to replace "Asian values" with "values in Asia." However, eliminating references to "Asian values" and replacing it with "values in Asia" will not put an end to substantive debates about the universality of rights or shed any light whatsoever on how rights are to be interpreted or implemented in particular contexts in Asia. Success in eliminating reference to "Asian values" certainly does not mean that all Asian countries will become liberal. Appealing to "values in Asia" merely shifts the focus to a less grand level, whether that be country by country, area of law by area of law, or issue by issue. ${ }^{239}$

As for the values part, Bell and others are surely right to point out that many of the issues have not been about values or culture, at least initially or primarily. As we have seen, some of the most contested issues were economic in nature, such as what regime type would be most likely to achieve sustained economic growth. This is ultimately an empirical issue, as is the relationship between Confucianism and economic growth, and whether civil and political rights must be traded off to ensure growth or social stability. But these are not only empirical issues; they are also heavily value-laden issues. Empirical studies may be able to demonstrate that Confucianism or authoritarianism

238. The theme of issue 41:4 of the Korea Journal was "Remaking of the Modern Family in Korea." The essays demonstrate unequivocally that there has been convergence. At the same time, they also show some significant differences that (at least for the time being) continue to persist, for better or for worse.

239. See Jiangyu Wang, China and the Universal Human Rights Standards, 29 SYRACUSE J. INT'L L. \& COM. 135, 136, n.9 (2001) (noting PRC government appealed to Chinese values in response to criticisms in U.S. human rights report on China). The PRC government has referred to "Chinese values" to support some of its actions. But the diversity of views within China leads to many of the same objections against Asian values. 
facilitates economic growth. However, empirical studies cannot answer the normative question whether higher growth under a Confucian or authoritarian regime is preferable to lower growth under a non-Confucian, democratic regime. Similarly, empirical studies might show that broad free speech laws may lead to more obscenity, less civility and even less social stability, but one would still have to decide whether the benefits of free speech outweigh such costs.

Fukuyama claims that "Asian values" is misleading in that the debate was about institutions rather than values: "values almost never have a direct impact on behavior; they must be mediated through a variety of institutions to make themselves manifest." 240 This is true, but as Fukuyama himself notes, values may influence the choice of institutions, their structures, and how they operate. That we must consider institutions does not mean we can ignore values. Similarly, Bell notes that debates about the economy and the role of social networks in the economy do not turn on efficiency considerations alone. They also depend on value judgments about what kind of society one would like to live in. In fact, Bell acknowledges that values are deeply held and may re-emerge even after years of government campaigns to change them. He cites as an example the strength of "filial piety" after the Cultural Revolution. ${ }^{241}$ $\mathrm{He}$ also notes how a model of corporate governance that emphasizes quick returns for shareholders may be difficult to sustain or implement in Japan. ${ }^{242}$

Cultural variables and values are often difficult to operationalize, and their effects are hard to determine in a rigorous way. However, that does not mean we can simply throw our hands up in the air and dismiss them. They are too important to be dismissed. We will simply have to make do as best we can with various methodologies from in-depth case studies to empirical surveys to comparative and historical studies of cases and the rationales given for the outcomes.

Bell also argues that "Asian values" is not a useful concept because it has been too politicized and tainted by its origins and association with Lee Kuan Yew. ${ }^{243}$ Perhaps so, but similar arguments are often made by Asianvalues proponents about human rights - they are tainted by their origins in the West. As noted, the proper response seems to be to focus on the substance of the arguments rather than the origin. Rights are either beneficial or they are not. "Asian values" is either useful or it is not.

Given the many reasons for invoking "Asian values", references to "Asian values," are likely to continue despite academic concerns about the term's analytical limitations. Empirical studies are needed to determine just how much common ground there is and on what issues. In the meantime, 
there is perhaps a middle ground between simply rejecting Asian values and endorsing the term without qualification. In discussing Asian variants of modernity, it is probably more useful in most cases to rely on more specific, substantive labels. To the extent that the nature of the project does require broad comparisons, the label "Asian" should be used with caution and, like other potentially dangerous items, come with warning labels and disclaimers attached. Moreover, in many instances, it may be possible to substitute the more pluralistic "values in Asia" for the more contentious "Asian values." While this would not end the debate about universalism versus localism, it would signal the desire to move away from the over-politicized first round debates to the more critical and nuanced views that have dominated the second round.

\section{Asian variants of modernity}

The "Asian values" debates arose in response to and owe their resilience in part to the feeling that liberalism is a failure and Asians must come up with their own normatively attractive variant(s) of modernism. It is important to distinguish between radical and moderate challenges to modernity in Asia. With Marxism having lost its appeal, Islamic fundamentalism is the main contender for a radical alternative. However, modernity has made inroads even in that sphere, perhaps weakening support for Islamic fundamentalism and forcing some degree of accommodation with modern institutions, including human rights. ${ }^{244}$

Apart from Islam, there are few credible radical challenges to the main pillars of modernity within Asia or elsewhere. There is widespread support for some form of a market economy, though Myanmar is only recently moving in that direction, marketization in Vietnam has been hindered by the lingering influences of socialism, and North Korea remains an economic basketcase stuck in the past. Of course there are many critiques of market capitalism and arguments for particular Asian or local variants. However, they do not add up to a radical challenge to market capitalism.

Although a number of states are still not democratic, and democracy seems a distant prospect in China, Vietnam, Myanmar, and North Korea, the long-term trend seems to be clear. Again, there may be varieties of democracy, but none of the current non-democratic regimes seems to offer a credible long-term alternative.

Rule of law is increasingly accepted in theory, if not always implemented in practice. Some commentators argue that Myanmar, North Korea,

244. While support for Islamic fundamentalism may or may not have been weakened by its association with the September 11 terrorist attacks, the bombings in Bali and other more recent attacks in the region, the United States' wars against Afghanistan and Iraq are likely to increase radicalism. 
Vietnam, China, and perhaps even Singapore and Malaysia are better understood as rule by law. ${ }^{245}$ Rule by law may capture the theory of law in North Korea and Myanmar and the practice in some of the other states. However, the other states all accept the basic rule of law principles that law is to be supreme and binding on government actors as well as citizens. All too often critics simply assume a liberal democratic rule of law as the benchmark and then dismiss Asian legal systems that do not comply with that standard as instrumental rule by law systems. However, the choice is not confined to either liberal democratic rule of law or rule by law. There are alternative conceptions of rule of law in Asia that nonetheless merit the label rule of law. ${ }^{246}$

Finally, the totalizing Marxist critique of rights as a tool of the bourgeoisie useful in inducing false consciousness in the proletariat is no longer credible. The more radical critiques argue that rights are not enough and that focusing on rights diverts attention from the need for fundamental change in the structures and institutions of society. Rights have not been sufficient to address the fundamental economic inequities that have accompanied capitalism even in the richest states, to overcome the imbalance of wealth between nations, or to do away with discrimination and ethnic hatred and strife. Thus, some critics advocates discourses of needs, capabilities or duties to complement rights talk. Others argue for a broader based conception of rights, not founded on secular liberalism, which builds on a more inclusive spiritual and moral worldview drawn from the world's great religions. ${ }^{247}$ However, even these critiques do not reject rights outright.

Moderate challenges to modernity in Asia accept the basic pillars of modernity, but try to construct local variants that avoid some of the excesses and shortcomings associated with Western liberalism. Just as libertarians, classical liberals, welfare liberals, conservatives, civic republicans, and communitarians differ over many issues in the West, so do Asians of various stripes. Given the diversity within Asia and within particular countries, a variety of alternative conceptions are possible. I have for example distinguished between four conceptions of rule of law in China: Statist socialist, neo-authoritarian, communitarian, and liberal democratic. ${ }^{248}$ One might also develop Islamic or Buddhist alternatives. One could also make increasingly finer specifications of the various forms. For example, there are no doubt many varieties of communitarianism or collectivism, much as there are many

245. Christie asserts: "[T]he notion of socialist authoritarianism is still concerned with the illiberal doctrine of rule by law rather than the liberal democratic perspective of the rule of law. This is typical of what states that promulgated the Asian values thesis attempted." CHRISTIE \& RoY, supra note 8, at 118.

246. See Peerenboom, supra note 7.

247. Chandra Muzaffar, From Human Rights to Human Dignity, in DEBATING HuMaN RIGHTS: CRITICAL ESSAYS FROM THE UNITED STATES AND ASIA, supra note 12, at 25-31.

248. Peerenboom, supra note 7. 
varieties of liberalism. Similarly, one could develop a number of different ways of characterizing market capitalism, democracy, and human rights.

In fact, many of the debates in the second round have been about more specific issues that tend to define local variants. With respect to the economy, the role of the state in Asian countries continues to be a major concern. Interestingly, although regulatory failure was one of the causes of financial crisis, several Asian states responded to the Asian crisis by setting up nonelected, elite, technocratic bodies to get their economies back on track. Other issues include the role of social networks, guanxi, corporatism, and clientelism. The issue is not whether informal social networks can substitute for rule of law and a formal legal system and still achieve sustainable economic growth. They cannot. ${ }^{249}$ Nor is it whether rule of law requires the complete dismantling of informal mechanisms for resolving disputes and the elimination of social networks. Informal mechanisms and social networks are a part of legal systems everywhere. There are many reasons that they exist, from institutional failure to cultural factors to their ability to serve people's needs in a cheaper, more efficient way. The question is how to maximize the benefits and limit the costs of such networks. ${ }^{250}$ A number of corporate governance issues have been debated including whether short-term profits for shareholders should be emphasized over employee interests, to what extent the impact of businesses on local communities should be considered, and whether there should be a stronger role for the government in coordinating research and making the results publicly available so as to increase the effectiveness of coordination among firms. ${ }^{251}$ Labor issues include, in some countries, the right to strike, and in other countries, issues such as lifetime employment and the promotion of the family through the adoption of workplace rules and government supported childcare programs. The pros and cons of different types of welfare systems have also been discussed. ${ }^{252}$ Other topics include the need for greater attention to an egalitarian distribution of wealth, corruption and good governance, and the affects of globalization.

249. See id.

250. The issue of social networks was much discussed in previous issues of the Korea Journal. See especially issue 41:3. It was also the focus of a recent conference on civil society and social networks in Asia, held in Hong Kong in April 2002. I discuss these issues at greater length in, Social Networks, Civil Society, Democracy and Rule of Law: A New Conceptual Framework, in THE POUTICS OFRELATIONALITY: CIVIL SOCIETY, ECONOMICS, AND LAW IN EAST ASIA, (Hahm Chaihark, Daniel Bell \& Hahm Chaibong, eds., forthcoming 2004).

251. Ha-sung Jang, Corporate Governance and Economic Development: The Korean Experience, in DEMOCRACY, MARKET ECONOMICS \& DEVELOPMENT, supra note 7, at 73-93.

252. See Kim Yeon-Myung, Welfare State or Social Safety Nets?, 41 KoREA J., Summer 2001, at 169. Kim argues that the welfare reforms of the Kim Dae-jung administration cannot be described as liberal, neo-liberal, corporatist or in terms of the Japanese model (sometimes referred to as the East Asian model) but rather is a hybrid reflecting characteristics of various regimes without consistent principles. 
The second round has also emphasized the need to look beyond democratic elections to public participation (both in terms of quantity and quality) and to increased transparency. There has been greater concern with mechanisms for holding governments accountable and for dealing with corruption and the diversion of state assets to private parties. The shortcomings of top-down Fordist or Weberian regulatory mechanisms have led to calls to localize and proposals for greater deregulation, bottom-up participatory mechanisms, negotiated rule-making, and the contracting out of regulatory functions. ${ }^{253}$ One issue has been the applicability of these "postmodern" responses to modern bureaucracies to countries that are still in the process of establishing the basic institutional infrastructure of modernity. ${ }^{254}$ Other topics receiving attention have been perfectionism versus liberal neutrality, the nature and role of civil society, freedom of the press, and the limits of free speech in relation to judicial independence.

Human rights were the primary focus of the first round, albeit at a high level of abstraction. As noted, in some cases such as North Korea and Myanmar, there seems to be little to say other than the regime has taken the wrong path and must mend its ways, as Myanmar is showing signs of doing. However, given the poverty in much of Asia, the most urgent issues in many cases have been economic. The second round has added little to the well-developed theoretical arguments and extensive (if on some issues inconclusive) empirical record about the relationship between regime type and economic growth. Furthermore, the second round has not had much impact on the more specific rights issues faced by authoritarian and democratic regimes alike. Such issues require extensive local knowledge and context-specific judgments. For instance, Hong Kong police refused to allow protestors of the Tiananmen anniversary to protest in front of the Central Government Offices, restricting them to the West Gate. The government argued that the decision was made on security grounds based on a threatened assessment of events involving recent protests over the controversial right-of-abode cases. ${ }^{255}$ The reasonableness of such restrictions is difficult to assess from Geneva or Washington. In economically advanced, relatively stable democratic regimes like Japan, South Korea, and Taiwan, many issues reflect "normal" politics and turn on differences of opinion over contested, difficult issues that involve the balancing of individual interests against other interests. Meaningful conclusions can only be drawn by looking at a range of such cases.

253. Michael Dowdle, Heretical Laments: China and the Fallacies of 'Rule of Law,' 11 CULTURAL DYNAMICS 285 (1999).

254. See Peerenboom, supra note 7.

255. May Sin-mi Hon, Rally Rights Curbed, Say Groups, S. CHINA MORNING POST, May 12,2002 , at 2 . 


\section{Confucianism}

A main focus of the second round has been to develop a "Confucian" alternative to liberalism. However, perhaps we ought to pause and consider how important Confucianism is today. The empirical basis for the claim that Confucianism is still important in contemporary societies seems rather weak. One might point to countries such as South Korea, Taiwan, and even Singapore as examples of modern states influenced by Confucianism. Yet, are these countries really Confucian in any meaningful sense? They are basically modern states that have not fully endorsed liberalism. But that does not make them Confucian.

It is often difficult to empirically verify the link between Confucianism and contemporary institutions or practices. Frequently, Confucianism is simply assumed to be doing the explanatory work when other alternatives seem just as likely. For example, Yi Tae-jin claims that a Confucian subconscious awareness led Korean presidents after the Third Republic to emphasize economic growth as the commanding objective. ${ }^{256}$ That may be, but how would one go about showing it? Many governments emphasize economic growth. How do we know that Korean presidents emphasized economic growth because of (subconscious) Confucian beliefs? Similarly, contemporary Confucian advocates are aware that many Asians have little understanding of Confucianism and cannot articulate its main beliefs. Nevertheless, many claim that these people still are Confucian because their actions are consistent with Confucian ideas and a Confucian worldview. Their Confucianism is revealed in their "habits of the heart." Perhaps so. Many people in the West are influenced by Christianity in ways that they may not be able to articulate and may not even be aware of. However, the situation becomes more problematic when there are multiple possible explanations for actions and multiple sources for particular beliefs. It may be true that some Chinese care for their parents out of a Confucian sense of filial piety. However, many may believe they owe their parents care and respect for other reasons. In fact, they may explicitly reject the idea that their actions are based on Confucian concerns about filial piety. More generally, some people may have expressly rejected Confucianism because of its anti-democratic character, emphasis on hierarchical relations, and tendency to lead to discrimination against women. Regardless of whether they are right about these points, it seems odd to describe them as Confucians because they may have been influenced in some ways by Confucian ideas. ${ }^{257}$ As someone who grew up in the West, I have no doubt been influenced by Christianity in some

256. Discussion: Asian Values, supra note 62, at 286 (showing comments of Yi Tae-ji).

257. Bell and Hahm refuse to describe anyone as a Confucian who explicitly rejects Confucianism. INTRODUCTION, in CONFUCIANISM FOR THE MODERN WORLD (Daniel A. Bell \& Hahm Chaibong eds., 2003). 
general ways and most likely even in some specific ways. However, it would be odd to describe me as a Christian if I expressly deny the existence of God and Jesus Christ, declare myself to be against Christianity, and claim to have converted to Buddhism. ${ }^{258}$

Choi Won-shik points out that for the debates to take a proper direction, the various aspects of Confucianism in Asia should be clearly understood and the various elements scrutinized. ${ }^{259}$ Yet, this is no easy task. A difficult threshold question is what is "Confucianism?" There is no accepted definition of Confucianism, and it is understandable why there is not. Confucianism is a vague term that covers two millennia of diverse ideas and practices. Identifying the key or core values or elements of Confucianism is problematic, to say the least. Yet in the absence of any attempt to state the key elements or to delineate the outer parameters of Confucianism, advocates of New Confucianism are left to their own devices. Thus, many scholars have scanned the tradition for values or practices that seem, at least on the surface, similar to values and practices associated with modernity while ignoring the context in which these ideas were embedded and all of the related values and practices that are inimical to modernity. When undesirable features are noted, they are quickly dismissed, generally by fiat, although in some cases interpretive strategies are employed to rehabilitate the texts. However, a tradition is more than just the sum of its parts. Traditions consist of integrally related clusters of concepts, ideas and values. What defines a tradition is the particular combination of concepts, ideas, and values. ${ }^{260}$

258. Confucianism is arguably more compatible with other belief systems than Christianity in that one can be a Confucian and many other things simultaneously. But the general point still remains that one could reject Confucianism, even a rehabilitated Confucianism, put in its most favorable light.

259. Discussion: Asian Values, supra note 62, at 287.

260. See ASIAN FREEDOMS: THE IDEA OF FREEDOM IN EAST AND SOUTHEAST ASIA (David Kelly \& Anthony Reid eds., 1998) [hereinafter ASIAN FREEDOMS]. With the issue of rights and democracy seemingly exhausted, some scholars have sought to shift the focus to related but distinct issues such as freedom. However, because the concept of freedom in its politically salient form is part of the cluster of concepts that defines modernity, the discussion then tracks the rights debates, with the same moves being made by the participants. The first move is to undermine the belief in the universality of freedom and the naturalness of freedom as an intrinsic value on both a theoretical and historical level. Theoretically, the argument begins by demonstrating that there are many different conceptions of freedom. The subject of freedom may be the individual, group or state (i.e. sovereignty and freedom of states from interference by other states). In contrast, freedom of individuals and groups may mean freedom from the state. At the same time, group freedom need not go hand in hand with freedom of individuals and indeed may be an obstacle to individual freedom. One could also distinguish between negative and positive freedom (freedom from interference by the state and other individuals or groups versus freedom to do something, which may entail positive obligations on the part of the state or others to provide resources or opportunities). When singing the praises of freedom today, much of the emphasis is on a specific kind of freedom-a liberal understanding of individual freedom, manifest in particular Enlightenment political institutions and social practices such as democracy, rule of law, civil society and individual rights (let us call it "liberal 
freedom," notwithstanding the awkward translation that this will give rise to in Chinese, in which both liberty/liberal and freedom are translated as ziyou).

Historians then point out the obvious, that freedom so understood is not universal. Rather, freedom as a "widely held vision of life" has emerged only recently as part of the Enlightenment. Comparative philosophers and area specialists jump in and show how this particular conception of freedom is at odds with religious and philosophical traditions in Asia. If not straightforwardly incompatible with such traditions, at minimum it is safe to say that freedom never played a central role in such traditions and did not become the subject of much theorizing. Moreover, social and political practices were not meant to foster freedom; indeed, quite the opposite-freedom was restricted in the name of other values such as stability and social order. See, e.g., Ian Mabbet, Buddhism and Freedom, in ASIAN FREEDOMS, at 19, 20 (demonstrating how the liberal conception of freedom does not fit well with traditional concerns of Buddhism, and concluding that "Buddhism contributed to freedom in some ways and limited it in others; in yet others it belongs to a different universe of thought."); W.J.F. Jenner, China and Freedom, in ASIAN FREEDOMS, at 65, 87 (documenting the ways freedom was limited and concluding that "[c]oncepts of freedom have had very little to do with China until the last hundred years" and even now encounter resistance).

The response of liberals and universalists is then to search the tradition for similar ideas or practices that seem supportive of freedom. However, they must first challenge the narrow modern conception of freedom, just as those looking for rights in Asian traditions have sought to move beyond the narrow understanding of rights as (deontic) anti-majoritarian legal entitlements enjoyed by individuals to a broader understanding of rights as moral rights. In some cases, they have emphasized certain functions of rights, thus making it possible to discuss rites $(l i)$ as rights, despite the fundamental differences in these concepts. $C f$. Peerenboom, Confucian Harmony and Freedom of Thought, supra note 137, at 247-52 (arguing that rites are not rights and eliding them merely produces conceptual confusion in the name of an ahistorical, anachronistic misreading). Thus, Kelly takes exception to Jenner's argument that freedom was not historically a prominent concem in China by objecting to his "severely defined" view of freedom, opting instead for a "looser and more multidimensional notion of freedom. ..." See David Kelly, The Chinese Search for Freedom as a Universal Value, in ASIAN FREEDOMS, at 94-98 (emphasis added). He then surveys the tradition for "a range of values and visions of life which can stand as precursors to freedom" citing Daoism and Buddhist notions of liberation, as well as the tradition of heroic rebels of All Men Are Brothers folklore. The title of Kelly's essay is revealing both of where his normative preferences lie and of the difficulty of making his case.

This move results in cries of bait and switch. These may be examples of freedom, but they are not freedom in the relevant sense in that they do not and did not lead to modern liberal conceptions of individual freedom, rights against the state, democracy, civil society, and so on. Rather they are embedded in a very different context and served different ends. Daoist hermits may have been free, but their freedom was apolitical.

At this stage, universalists may opt for the strategy typical of the second round-that is, rather than arguing about whether freedom in the relevant sense is part of the tradition or compatible with certain belief systems, they simply stipulate that freedom is an essential part of modernity and traditions must adapt accordingly. Kelly, at 94 ("Notions of civilisation, modernity and development have proven both irresistible and almost impossible to decouple from the liberal ideology of political freedom they are said to entail."). To overcome the suggestion that it might not be possible to adapt Asian traditions to the demands of modernity, universalists note how some Asian countries such as South Korea, Taiwan, and Japan have become democratic and endorsed a variety of rights. Thus, they conclude, freedom is consistent with "Asian values" (it bears noting that this strategy reinforces the notion that freedom is part of a cluster of concepts, values and institutions peculiar to modernity). The preferred liberal/ universalist strategy for dealing with those countries that have resisted democracy and liberal rights, such as China and Singapore, is to pick out a few liberals and emphasize their views, 
New Confucians suggest that Confucianism can be adapted to modern times and that to claim otherwise is to essentialize Confucianism in an inappropriate way. In one extreme articulation of this view, Roger Ames claims that even to ask the allegedly "Western analytical" question "what is Confucianism?" essentializes Confucianism by "treating it as a specific ideology that can be denoted with varying degrees and accuracy." ${ }^{261}$ He suggests that "this assumption is likely to add confusion."262 In his view, "what is an interrogative perhaps appropriate for attempts at systematic philosophy, from Plato to Freud, but it is not appropriate in reading a fundamentally aesthetic tradition which takes as its basic premise the uniqueness of each and every situation." ${ }^{263}$ Rather, we need to ask how Confucianism functions. We should view Confucianism as a continuing cultural narrative rather than as (a set of) isolatable doctrines and ideologies. Thus, claims Ames, "any particular doctrinal commitment or set of values that we might associate with Confucianism needs to be qualified by its resolutely porous nature, absorbing into itself, especially in periods of disunity, whatever it needs to thrive within its particular historical moment." 264 Why call whatever results "Confucianism," you might wonder-"because any narrative must have a proper name.",265

notwithstanding that liberals may be a distinct minority in these countries. Kelly, at 108-14.

When forced to admit that liberalism is but a minority view, the response is to shift to normative ground and argue that freedom is a universal value. Even allowing that historically Asian traditions did not endorse liberal freedom and that liberals are in the minority, liberal freedom should prevail. Id. at 114 . The responses to this move track the rights debate. One response is to question the normative value of freedom. In many cases, critics can draw on critiques from those in Western countries who point out the limits of freedom and the shortcomings of Western societies-freedom cannot be so wonderful if it results in the chaos of American cities and the isolated monadic lifestyle of suburbia, where busy parents commute from home to office in their air-conditioned, environmentally degrading boxes on wheels. In other cases, the critiques may proceed from the perspective of indigenous traditions by challenging the values and assumptions of the liberal worldview in which the modern discourse of freedom is embedded. Critiques may be radical or partial. Rather than rejecting freedom outright, the argument may be about degrees of freedom and how freedom is to be implemented given existing institutions and circumstances.

As in the rights debate, the next step is to move beyond grand, universal claims about freedom to context-specific discussions that bring out more clearly issues of power and whose freedom is being pursued at whose expense. See, e.g., Vera Mackie, Freedom and the Family: Gendering Meiji Political Thought, in ASIAN FREEDOMS, supra, at 121-40 (discussing Confucian and liberal discourses and their relation to the struggle of women for freedom); Anthony Reid, Merdeka: The Concept of Freedom in Indonesia, in ASIAN FREEDOMS, supra, at 141-56 (noting charged emotional appeals to merdeka or freedom in colonial struggle for independence). The wonder of the second round is that the entire cycle can be completed within a single volume.

261. Roger Ames, New Confucianism: A Native Response to Western Philosophy, in ChINese Political Culture, 1989-2000, 71 (Shiping Hua ed., 2001).

262. Id.

263. Id.

264. Id. at 80 (emphasis added).

265. Id. at 73 . 
Ames' view confuses form with content. There is nothing inherently illogical or nonsensical in asking "what" questions of narratives. We often ask someone what a book or movie is about. What would seem nonsensical (though it could still be aesthetically pleasing or fun) is a "story" or rather non-representational art that had no plot, no content-nothing that could be said in response to the question "what is it about?" Indeed, the very notion of a narrative implies some connection between what came first and what comes after. Noting that the story may have different parts or sequels-like Rocky I, $I I, I I I$ or $I V$-does not render the "what" question moot. One would still expect that someone walking out of a Rocky marathon could answer with a summary of the contents of each movie (assuming, that is, anyone could still be coherent after four movies, particularly mind-numbingly banal jingoistic Rocky movies). One would also expect that the respondent could have something intelligible to say about the series as a whole. Of course, one might expect some lesser degree of coherence, given that the movies were made over several years and perhaps written, produced, and directed by different people. $^{266}$

Perhaps even more problematic is the idea that Confucianism is so porous because of its narrative nature that it could transform itself into Rawlsian liberalism or Nazi Fascism depending on the time. It would seem that Ames is willing to allow any and all elements of Confucianism to change over time into anything whatsoever. Setting aside for the moment the difficulty of defining with precision the core elements of Confucianism, let us assume for the sake of argument that, as Ames has argued, he (harmony), ren (benevolence), $y i$ (righteousness), and $l i$ (rites) are important aspects of classical Confucianism (which shows that we can ask and answer "what" questions about Confucianism, at least for a particular period or author/ text) ${ }^{267}$ Presumably, given Ames' view, even if under the pressure of modernity New Confucians rejected each of these and adopted the opposite view of non-he, non-ren, non-yi, non-li, we would still be entitled to call this doctrine Confucianism. I see little point in calling any such doctrine Confucianism. Confusionism, perhaps, but Confucianism, no. The only seeming purpose

266. This is also true of any multi-author tradition based on systematic first principles such as Kantianism or liberalism. We recognize differences between Kant and Rawls, or between Rawls and Dworkin, for example. But we describe them as (neo-)Kantians, or as liberals, because of certain identifiable shared beliefs. The only difference seems to be that it is easier to identify the commonality and differences in their views because these philosophers set out their assumptions and arguments in a more explicit way than did early Confucians and even most New Confucians today. However, there is nothing to prevent New Confucians today from systematically defining the contents and scope of New Confucianism just as Rawls has done for his version of liberalism. In fact, philosophers such as Joseph Chan are trying to do just that.

267. These are the standard, admittedly not very felicitous, translations of these terms. Ames has his own preferred translations of these terms and his own views about what they mean. See DAVID HALL \& ROGER AMES, THINKING THROUGH CONFucIUS (1987). 
would be to take advantage in bad faith of whatever normative authority comes from invoking Confucianism.

To be sure, in practice it is not possible that Confucianism could or would actually transmute into just anything. Certain changes would simply not be seen as attractive or feasible given the mindset and dispositions of those within the tradition. Perhaps then we should not push Ames' comments to their extreme logical conclusion. Rather, his comments should be read as making a rhetorical point that emphasizes how Confucianism, like other discourses, traditions, and-isms, is capable of evolution and change. This makes the narrative less "porous," but still allows for considerable change. It also allows Confucians to rule out certain objectionable paths such as Fascism. It may also render moot or diminish the importance of stating in advance the defining elements of Confucianism or laying out all of the possible outer parameters of Confucianism. Rather than dreaming up unrealistic hypotheticals, we need only consider on a case-by-case basis actual possibilities in particular historical circumstances. However, this still leaves open the key issues of this era-whether Confucianism is consistent with modernity, including democracy, human rights, and rule of law; whether there is a coherent Confucian variant of modernity that can serve as a morally attractive alternative to liberalism; and if so, what that is.

Rather than arguing for the infinite elasticity of Confucianism on theoretical grounds having to do with the (essential?) nature of Confucianism as a narrative, some scholars, such as Bell and Hahm, respond to the compatibility issue by taking a more historical tack, showing the various ways in which Confucianism has changed in response to the times. ${ }^{268}$ Thus, they argue that Confucianism was able to survive the transition to a centralized state in the Han by reinventing itself under the guidance of Dong Zhongshu as a bureaucratic ideology prepared to serve the interest of the empire by incorporating elements of yin-yang five phases ideology. They also argue that Song Neo-Confucians were able to reinvent the tradition that eventually became the "orthodoxy" for most parts of East Asia, by constructively engaging Buddhist and Taoist philosophy. More specifically, the new schools of Confucianism incorporated "everything from Buddhist epistemology and Taoist cosmology to philosophical diagrams and methods of contemplation."269

That Confucianism could assimilate certain elements of certain traditions does not mean that it is compatible with contemporary conceptions of democracy, rule of law, and human rights. Moreover, the fact that scholars felt the need to come up with a new label for Neo-Confucians suggests that there were sufficient differences to distinguish between the views of Confucius and Mencius and their Song dynasty counterparts. It may be the case that there is still enough common ground to continue using Confucianism for these 
various thinkers. However, at some point, perhaps when Confucianism embraces Rawls' two principles of justice, the usefulness of referring to the new doctrine as Confucianism (setting aside for the moment the internal coherence of any such system) will be outweighed by the tendency to create confusion. $^{270}$

Another approach has been to point out that Christianity was once opposed to democracy and human rights, but that it later came to support them, thus implying that Confucianism could do the same. ${ }^{271}$ However, this will not suffice without further argument. At minimum, we need a careful analysis of how Christianity was opposed to democracy in theory and practice and then a careful historical study of how it came to be supportive. We would then need a similar effort for Confucianism. Finally, we would need to compare the results of the two studies to see if the factors involved in the transformation of Christianity from obstacle to facilitator also apply in the case of Confucianism. Just because one tradition can change does not mean another can do the same. Christianity may have been more compatible with democracy and human rights to start with than Confucianism.

Confucianism is a living tradition and traditions change. However, that does not mean that one is free to attribute anything one wants to Confucianism or that Confucianism can assimilate any and all ideas from other traditions and still be considered Confucianism in any meaningful or useful sense. It may be possible to reject by fiat some ideas-such as the subjugation of women--in favor of other ideas. However, can one reject the notion of a paternalistic government or the inegalitarianism inherent in the li/rites, assuming one would want to? Moreover, can one simply substitute democracy and elections as the basis for legitimacy rather than the traditional moral cultivation of the leaders and the mandate of heaven? Although New Confucians suggest that Confucianism can be adapted to modern times and that to claim otherwise is to essentialize Confucianism in an inappropriate way, there are many thorny methodological issues that arise in the process of rendering Confucianism compatible with modernity.

While it seems necessary for Confucianism or any other tradition to come to grips with modernity and be adapted accordingly or simply perish as a viable political system, it may be that there can be Confucian variants of capitalism, democracy, rule of law, and rights. We may no longer be dealing

270. Bell argues there are very good reasons why Confucians would not embrace Rawls' principles. Most importantly, Confucians would be reluctant to give "lexical priority" to the first principle that secures civil and political rights in cases of conflict with the second principle that secures (the functional equivalent) of social and economic rights. As he points out, one of the earliest and most influential Confucian political values is that the first obligation of the state is to secure people's basic material well being. See CONFUCIANISM FOR THE MODERN WORLD, supra note 257.

271. Discussion: Asian Values, supra note 62, at 244 (showing comments of Kang Jung In). 
with Confucianism per se, but rather with Confucian-inspired or -influenced variants of contemporary institutions. The new system might have enough Confucian elements to differentiate itself from liberalism as practiced elsewhere, but be too different from and too much at odds with core elements of what has historically been known as Confucianism to merit that label. Indeed, what remains of Confucianism today seems less like a coherent system and more like isolated values, often hardly unique to Confucianism, that serve as a communitarian corrective on liberal extremism. ${ }^{272}$ If that is true, it might be that Confucianism will only affect the institutions of modernity at the margins and in a piecemeal, ad hoc fashion that does not add up to a coherent Confucian alternative to liberalism. ${ }^{273}$

As there may not be much gained by hanging on to the label of Confucianism at this point, perhaps the focus should shift to developing communitarian or collective alternatives to, or variants of, liberalism without worrying so much about the link to Confucianism. However, even if there is some explanatory power in Confucian communitarianism, Confucian democracy, Confucian rule of law, Confucian human rights or even a Confucian liberalism, much more work needs to be done to develop these ideas into coherent concepts and to spell out in sufficient detail the implications of these alternative forms of modernity in terms of institutions, norms, legal rules, social practices, and outcomes. Assuming Confucianism is compatible with democracy or that we are simply going to stipulate that democracy is unavoidable and turn our attention to developing a form of Confucian democracy, what will that be? How does it differ from liberal democracy? What are its distinctive institutions, practices and values? Will it have a divided legislature with one chamber controlled by elites? ${ }^{274}$ If so, what exactly will the division of power be? On what issues will the elites have ultimate authority? Similarly, what are the defining characteristics of a Confucian rule of law? Will the purposes of the law and legal system be to limit or strengthen the state, to protect individual rights or, more likely, some balance between the two, and if so, what balance? Will there be a role for rule of virtue (de zhi) as well as rule of law-as advocated by that born-again New Confucian Jiang Zeminand how will the two relate and be reconciled? Will there be any distinctive institutions-such as the censorate from the Imperial era to check government

272. There may be many elements of Confucianism that inform the Chinese worldview that are not relevant to social and political philosophy or are too abstract to have much bearing on practical issues (such as the nature of Confucian cosmogony, a pragmatic based epistemology that emphasized know-how rather than knowing - that or arguably even the conception of self as a social being).

273. Presumably, Confucian liberalism would be what you would get if you accepted Rawls's criteria of justice, but introduced various Confucian elements at the margin to give the system a particular Confucian flavor. However, that is not Confucianism, but rather a Confucian-tinged variant of liberalism.

274. DANIEL A. BELL, EAST MEETS WEST: HUMAN RIGHTS AND DEMOCRACY IN EAST ASIA (2000). 
power? A letter and petition system whereby citizens can beseech government leaders for help? An ombudsmen system? Will there also be the usual modern institutions: administrative reconsideration bodies, a constitutional review entity, and an independent judiciary capable of conducting judicial review of government acts? If so, will they operate on different principles? How independent will the judiciary be, and on what issues? Will the courts be responsible for deciding cases in terms of a normative agenda-a particular conception of the good-decided by moral elites? What will be the role of the legal profession? Will lawyers have greater duties to society as opposed to their individual clients? What will the Confucian conception of rights entail? Will there be a different conception of or importance attached to autonomy? What are the justifications for and limitations on free speech and other civil and political rights? How will gender issues be handled? What is "the" New Confucian position on same-sex marriage, equal pay, the inheritance rights of women, and inheritance rights more generally?

\section{CONCLUSION: ROUND THREE AND BEYOND}

The first round should be seen as a necessary stage in an ongoing debate or discussion. Despite the excessively politicized nature of much of the discussion, the lack of an empirical foundation for many claims and a number of bad arguments, the first round did lay the foundation for future discussion and result in considerable progress on many issues. At least many of the issues were clarified to the extent possible given the subject matter. The available evidence was collected and brought to bear on a few key economic issues. In some cases, the need for more or different kinds of evidence became clear while in other cases it became clear that no amount of empirical evidence would resolve all of the disputes and that reasonable people are likely to continue to disagree.

The next round is likely to continue the trend of the second round to move beyond universalism and relativism by focusing on particular legal issues, politics, and sociological studies. In light of the heavily politicized nature of the first round, many have called for greater attention to discourse contexts and the different purposes and agendas of the participants. ${ }^{275}$ It may be any discussion of Asian values will be politicized to some extent, but some contexts are much more politicized than others. Cultural and values claims may also play a greater role in some contexts than others. The next round could benefit from a closer look at the use of Asian values, and cultural arguments more generally, in different contexts. How do international courts treat cultural claims and arguments? What role do cultural claims and arguments play in bilateral and multilateral relationships? Does the role vary depending on the issue? What role do they play in regional legal and political regimes 
and in domestic affairs? What is the role of culture and values when domestic courts interpret and implement international human rights? How, where, when, and why do INGOs and NGOs invoke culture?

The debate over Confucianism is likely to continue; perhaps some of the empirical, methodological, and theoretical issues mentioned above will be addressed. However, we must also move beyond Confucianism to consider the role of Daoism, Islam, Hinduism, and Buddhism in developing local variants of modernity. There also should be greater efforts to develop communitarian or collective alternatives to liberalism that need not be based directly on existing religious traditions. These projects will require both empirical and theoretical work.

Posner has argued that academic moral theory is useless. ${ }^{276}$ Moral theory is too abstract to resolve most real issues. As Posner notes, there are generally good arguments on all sides of broad philosophical issues, and the lack of any agreed means of demonstrating which side is "really" right means that people will be able to maintain their initial positions. Even some of Rawls' biggest supporters among law professors question whether Rawls' views have had any impact on American law or influenced the outcome of specific cases. ${ }^{277}$ "When Rawls ... descends from the abstractions of political philosophy to concrete issues of law and public policy, he becomes a superficial dispenser of the current 'liberal' dogmas concerning abortion, campaign financing, income distribution," and so on. ${ }^{278}$ This is not to deny that philosophers may make a valuable contribution to the debates. They may spot bad arguments, clarify issues, and point out errors in logic or reasoning. ${ }^{279}$ However, for the most part, what is needed is more factual information about the consequences of different options rather than abstract moral theories.

I both agree and disagree with Posner's views. In general, I do not think people are persuaded by rational arguments as much as they are driven by their intuitions and emotions. I also side with Posner, Richard Rorty, and others who argue that a good story and appeals to emotions and sentiments are more likely to lead people to change their views and behavior than philosophical arguments. ${ }^{280}$ Certainly they have a greater capacity to motivate than rational arguments. After all, believing something is right and doing it are very different things. Based on my own encounters, I doubt moral philosophers are more moral in their actions or show more consistency between belief and action than non-philosophers. To that extent, prophets or

276. POSNER, supra note 36.

277. Id. at 82 .

278. Id. at 58.

279. See Laura Carrier, Making Moral Theory Work for Law, 99 CoLUM. L. REV. 1018, 1019 (1999) (explaining that while moral theory may not be able to resolve many disputes, it serves a useful purpose in articulating the problems and ensuring that all relevant arguments have been heard).

280. See RICHARD RORTY, CONTINGENCY, IRONY AND SOLIDARITY (1989). 
moral entrepreneurs (to use Posner's phrase) are more likely to have a significant social impact than philosophers-think Lee Kuan Yew, Mao Zedong or even Deng Xiaoping.

On the other hand, the debates over Asian values, Confucianism, and communitarian alternatives to liberalism have suffered from the lack of a systematic, coherent theory (or theories). It may be that moral philosophers generally dress up in academic language the prevailing views of their times or their set. ${ }^{281}$ In that sense, Rawls' main contribution was to systematize the way many Americans felt. However, that is not an insignificant contribution. Moreover, while many judges and citizens may not have read Rawls, others have. There is a general sense that liberalism has some proper intellectual foundations. Of course, there are many who would disagree, and there are significant points of contention among liberals. Nevertheless, there is still some sense that at least a powerful theory exists. This sense trickles down to others in academia, then into the media, and then into the general public sometimes via moral entrepreneurs who "popularize" Rawls.

In contrast, communitarianism, whether in the West or in Asia, always seems less reputable, less solid, because of the lack of a systematic theoretical exposition. It seems more like a marginal critique of liberalism than a credible, full-fledged alternative able to stand on its own. The same is true of Asian (Confucian) (communitarian/collectivist) alternatives to liberalism. They have yet to be properly developed into a coherent, systematic theory. We are still waiting for an Asian (Chinese, Korean, Thai, Buddhist, Confucian, Islamic, sectarian communitarian) Rawls to synthesize the intuitions, values, beliefs, practices, and institutions that reflect a normatively attractive systematic alternative to liberalism. We are still waiting for some new theory that is compatible with modernity, but sufficiently different to be more than just a variant of liberalism. To date, the attempts to articulate a Confucian alternative to liberalism generally have been either too abstract, proceeding without any reference to institutions or concrete issues, ${ }^{282}$ or too piecemeal, discussing specific institutions that at best seem marginal to a functioning legal or political system while ignoring much more basic and central issues about democracy, rule of law, and human rights. ${ }^{283}$

281. POSNER, supra note 36 , at 81.

282. For an attempt to develop a Deweyean-Confucian alternative to liberalism, see DAVID L. HALl \& ROGER T. AMES, THE DEMOCRACY OF THE DEAD: DEWEY, CONFUCIUS AND THE HOPE FOR DEMOCRACY IN CHINA (1999). WM. THEODORE DE BARY, supra note 6, argues for a more liberal form of Confucian communitarianism. While admirable preliminary attempts to sketch a philosophical theory of Confucian communitarianism exist, neither account addresses in any detail the issue of rule of law nor provides details regarding political or legal institutions, legal rules or outcomes with respect to particular controversial issues. Bell's East Meets West is an exception in that it contains both a theoretical discussion of nonliberal democracy and consideration of institutions and specific issues. Nevertheless, it is more of a sketch than a detailed presentation, with many crucial issues left open.

283. See, e.g, CONFUCIANISM FOR THE MODERN WORLD, supra note 257. 
What is needed as a first step is a broader empirical, institutional and comparative framework. For example, several of us are now engaged in a project on rule of law that will examine legal system development and rule of law in Asia, using the legal systems of the United States (a common law country) and France (a civil law country) as comparison points. ${ }^{284}$ Given the great diversity among legal systems, the purpose is to understand how rule of law is conceived and implemented, and the role of law in economic development, political reform, the protection of human rights and geopolitical stability. We will look at a series of concrete issues in different areas of law including constitutional and administrative law, criminal law, environmental law, and family law and also examine issues such as the relation between law and morality. The project may generate a menu of options with respect to institutions, rules, norms, practices and outcomes on particular issues that can be used by theorists to develop a more credible theoretical alternative to liberalism. Similar studies are needed with respect to varieties of democracy and capitalism.

However, empirical studies by themselves are not sufficient. There is still a need for bold and creative thinking. One of the problems has been the dominance of the liberal democratic paradigm. Today, many of the leading Asian academics are trained in the West. Even those who have not studied abroad are often as well versed in the Western political, economic, and legal literatures as they are in the literatures of their own countries. ${ }^{285}$ It is important to understand Western systems in detail, to go beyond a superficial, usually excessively rosy account, to the realities of Western countries. At the same time, Asian theorists must also be firmly situated in their own context, with a solid grasp of institutional issues, and be willing to shake off liberal dogma and follow their own intuitions. In fostering critical reflection on Asian values, the second round of debates has increased the likelihood of the emergence of this kind of a bold, new theory. Perhaps we will see it come to fruition, if not in the third round, then in later rounds of what will no doubt be a never-ending attempt to come to grips with both our commonalities and our differences.

284. For an overview of the project, see the preface to ASIAN DISCOURSES OF RULE OFLAW, supra note 59.

285. Sonia Harris-Short, International Human Rights Law: Imperialist, Inept and Ineffective? Cultural Relativism and the UN Convention on the Rights of the Child, 25 HuM. RTS. Q. 130, 149, 171 (2003) (noting how many delegates to the U.N. from developing countries "adopt a positively hostile attitude towards culture and traditions of their own people" and end up supporting "policies at the state and international level which provide important support for international human rights but which, in various ways, betray and undermine the cultural values of the people they purportedly represent."). 
